\title{
A review of the systematic biology of fossil and living bony-tongue fishes, Osteoglossomorpha (Actinopterygii: Teleostei)
}

\author{
Eric J. Hilton ${ }^{1}$ and Sébastien Lavoué2,3
}

The bony-tongue fishes, Osteoglossomorpha, have been the focus of a great deal of morphological, systematic, and evolutionary study, due in part to their basal position among extant teleostean fishes. This group includes the mooneyes (Hiodontidae), knifefishes (Notopteridae), the abu (Gymnarchidae), elephantfishes (Mormyridae), arawanas and pirarucu (Osteoglossidae), and the African butterfly fish (Pantodontidae). This morphologically heterogeneous group also has a long and diverse fossil record, including taxa from all continents and both freshwater and marine deposits. The phylogenetic relationships among most extant osteoglossomorph families are widely agreed upon. However, there is still much to discover about the systematic biology of these fishes, particularly with regard to the phylogenetic affinities of several fossil taxa, within Mormyridae, and the position of Pantodon. In this paper we review the state of knowledge for osteoglossomorph fishes. We first provide an overview of the diversity of Osteoglossomorpha, and then discuss studies of the phylogeny of Osteoglossomorpha from both morphological and molecular perspectives, as well as biogeographic analyses of the group. Finally, we offer our perspectives on future needs for research on the systematic biology of Osteoglossomorpha.

Keywords: Biogeography, Osteoglossidae, Paleontology, Phylogeny, Taxonomy.

Os peixes da Superordem Osteoglossomorpha têm sido foco de inúmeros estudos sobre a morfologia, sistemática e evolução, particularmente devido à sua posição basal dentre os peixes teleósteos. Fazem parte deste grupo os "mooneyes" (Hiodontidae), "knifefishes" (Notopteridae), o "abu" (Gymnarchidae), peixes-elefante (Mormyridae), aruanãs e pirarucu (Osteoglossidae), e o peixe-borboleta africano (Pantodontidae). Esse grupo de morfologia heterogênea possui um longo e diverso registro fóssil, incluindo táxons de todos os continentes, oriundos tanto de depósitos de água doce quanto marinhos. As relações filogenéticas dentre a maioria das famílias de osteoglossomorfos é amplamente aceita. Entretanto, há muito a ser descoberto sobre a sistemática biológica desses peixes, particularmente com relação às afinidades filogenéticas de inúmeros fósseis, relações dentro de Mormyridae, e a posição filogenética de Pantodon. Neste manuscrito nós revisamos o atual estado de conhecimento dos peixes osteoglossomorfos. Nós primeiramente provemos uma abordagem geral da diversidade de Osteoglossomorpha, e então discutimos os estudos filogenéticos sobre Osteoglossomorpha sob a perspectiva morfológica e molecular, assim como uma análise biogeográfica do grupo. Finalmente, oferecemos nossas perspectivas sobre os futuros passos para pesquisa sobre a sistemática biológica de Osteoglossomorpha.

Palavras-chave: Biogeografia, Filogenia, Osteoglossidae, Paleontologia, Taxonomia.

\section{Introduction}

Osteoglossomorpha - the bony-tongue fishes - have been the focus of a great deal of morphological, systematic, and evolutionary study, due in part to their basal position among extant teleostean fishes (e.g., Greenwood et al., 1966; Nelson, 1969; Greenwood, 1973; Taverne, 1979, 1998; Li, Wilson, 1996a; Hilton, 2003; Wilson, Murray, 2008). Among the world's extant ichthyofaunal, this is a widespread group of primary freshwater fishes, including the neotropical genera Arapaima and Osteoglossum, the North American genus
Hiodon, and several Old-World groups, including the Mormyridae, Gymnarchus, Pantodon, Heterotis (Africa), Notopteridae (Africa and Southeast Asia), and the Australasian genus Scleropages. In addition, this morphologically heterogeneous group has a long and diverse fossil record, including taxa from all continents and both freshwater and marine deposits (Forey, Hilton, 2010). In their pivotal classification, Greenwood et al. (1966) formally established the modern conceptualization of crown-group Osteoglossomorpha, although all families had been more or less associated with one another by ichthyologists for some time (e.g., Ridewood, 1904, 1905;

\footnotetext{
${ }^{1}$ Virginia Institute of Marine Science, College of William \& Mary, P.O. Box 1346, Gloucester Point, 23062 VA, USA. ehilton@vims.edu, (Dhttps://orcid.org/0000-0003-1742-3467 (corresponding author)

${ }^{2}$ Institute of Oceanography, National Taiwan University, N¹ Sec. 4 Roosevelt Road, Taipei 10617, Taiwan. microceb@hotmail.com ${ }^{3}$ Current address: School of Biological Sciences, Universiti Sains Malaysia, 11800 Pulau Pinang, Malaysia.
} 
Garstang, 1931; Gosline, 1960). Two characters were offered to support this grouping: the presence of a so-called "parasphenoid-tongue bite" and the presence of "paired, usually ossified, rods at the base of the second gill arch" (Greenwood et al., 1966:361). Although both of these characters have been shown to be complex characters, with different aspects of each defining different subgroups within Osteoglossomorpha (Hilton, 2001), the monophyly of the group has been well established and accepted (see discussion by Hilton, 2003).

The importance of Osteoglossomorpha for understanding early teleostean evolution has been long appreciated (e.g., Greenwood, 1973; Patterson, Rosen, 1977; Patterson, 1977; Arratia, 1997). Osteoglossomorpha was among the first vertebrate taxa to have their relationships analyzed in a cladistic framework (e.g., Nelson, 1968), and have also been used to exemplify general patterns, for instance, of biogeography (Nelson, 1969; Patterson, 1981). Based on a series of osteological descriptions (e.g., Taverne, 1972, 1977, 1978), Taverne (1979) first proposed the general pattern of relationships among extant taxa that is widely adopted today, namely that Hiodontidae is the sister group of all other extant osteoglossomorphs, Notopteridae and Mormyroidea (Gymnarchidae + Mormyridae) are each other's closest relatives, and Osteoglossidae has two subfamilies (Arapaima + Heterotis and Osteoglossum + Scleropages, with Pantodon more closely related to the latter). This set of relationships was maintained by Li, Wilson (1996a), the first published computer-assisted cladistic analysis of Osteoglossomorpha. In the last 25 years there have been several studies of the relationships within Osteoglossomorpha, with broad congruence (with only a few exceptions) regarding their relationships, at least among extant taxa. However, there is still much to discover about these fishes, particularly with regard to the phylogenetic affinities of several fossil taxa and the position of Pantodon. The most recent review of the Osteoglossomorpha was conducted by Wilson, Murray (2008). Since that review, there have been numerous new data published on their morphology, many new fossil taxa described or redescribed, as well as renewed study of their biogeogra- phy and their phylogeny based on genetic data. Osteoglossomorpha is at the same time both a well-studied taxon and one in need of new and focused study at all levels.

In this paper we review the state of knowledge for osteoglossomorph fishes, emphasizing studies published since Wilson, Murray (2008). We first provide an overview of the diversity of Osteoglossomorpha, using the family-level taxonomy presented by Nelson et al. (2016) as a framework for this discussion. We then discuss studies of the phylogeny of Osteoglossomorpha from both morphological and molecular perspectives, as well as biogeographical analyses of the group, with a particular emphasis on recent studies; the earlier history of the study of this group is described in more detail by Greenwood et al. (1966), Hilton (2003) and Wilson, Murray (2008). Finally, we offer our perspectives on future needs for research on the systematic biology of Osteoglossomorpha.

\section{Diversity of Osteoglossomorpha}

$\dagger$ Lycopteridae and other Stem-Group Osteoglossomorpha. $\uparrow$ Ichthyodectiformes, a group of predatory Jurassic and Cretaceous fishes (Cavin et al., 2013), had been closely associated with Osteoglossomorpha (e.g., potentially within Osteoglossomorpha by Greenwood et al., 1966; Taverne, 1979), due in part to general body form and superficial similarity. It was shown by Patterson, Rosen (1977), however, that †Ichthyodectiformes was best interpreted as a stem-group Teleostei, phylogenetically separate from Osteoglossomorpha, and this has been supported in recent analyses of relationships among basal teleostean fishes (e.g., Arratia 1997, 1999, 2008).

Members of $\dagger$ Lycopteridae (Fig. 1) are a group of generalized, plesiomorphic osteoglossomorph fishes. According to Nelson et al. (2016), three genera are included in the family (†Lycoptera, †Jiuquanichthys, and $\dagger$ Kuyangichthys), although Zhang (2006) found the relationships of all of these basal genera to be largely unresolved along the stem of Osteoglossomorpha. The recently described monotypic genus $\dagger$ Kokuraichthys from the Early Cretaceous of Japan was in-

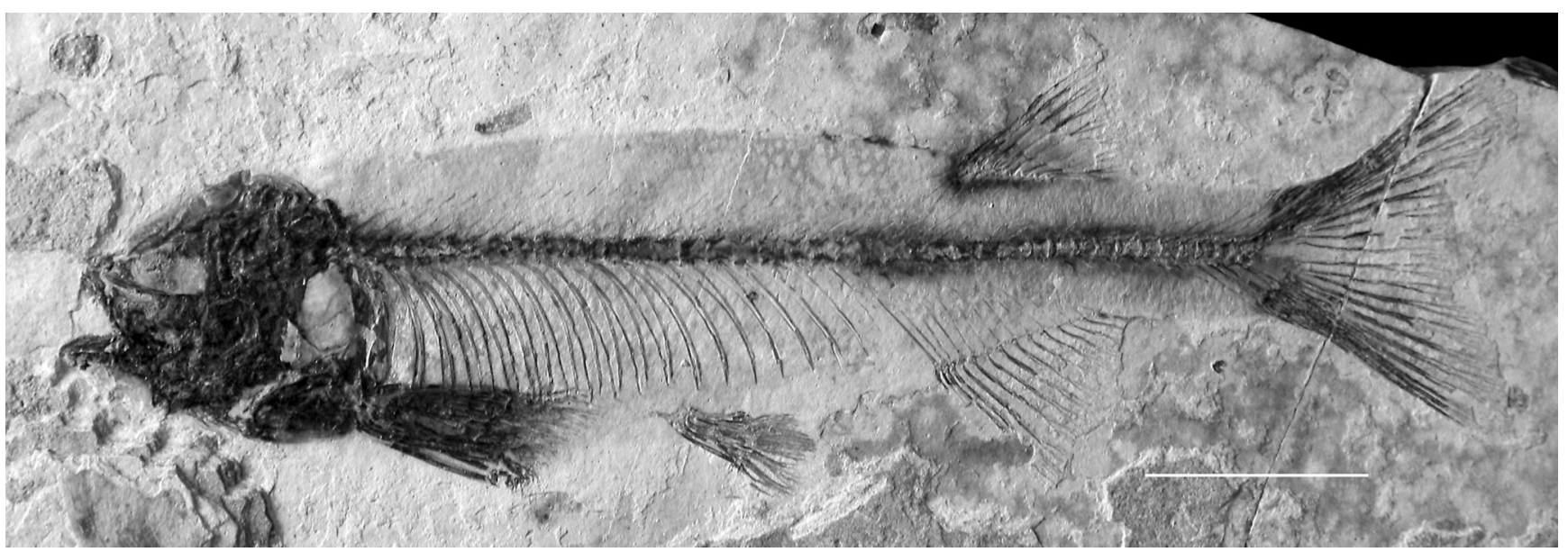

Fig. 1. †Lycopteridae. Lycoptera davidi, Early Cretaceous, China (UMA F10652; $110 \mathrm{~mm} \mathrm{SL).} \mathrm{Scale} \mathrm{bar}=2 \mathrm{~cm}$. 
terpreted to be either a member of $\dagger$ Lycopteriformes (co-extensive with $\dagger$ Lycopteridae) or Hiodontiformes (Yabumoto, 2013). A number of possible stem-group osteoglossomorphs have been identified, but not assigned to a specific family (including some taxa included within †Lycopteridae). Without exception, these fishes come from Early Cretaceous deposits in Asia, primarily China. Included among these taxa are $\dagger$ Jinanichthys, $\uparrow$ Tongxinichthys (Fig. 2a; see Zhang, Jin, 1999), and $\dagger$ Xixiaichthys.

The group $\dagger$ Huashia $+\dagger$ Kuntulunia (Fig. 2b) has been interpreted as both a stem-group (e.g., unresolved node with Hiodontiformes and all other osteoglossomorphs; Zhang, 2006), sister to Notopteroidei + Osteoglossidae (Zhang, 1998), or as more closely related to Arapaiminae (e.g., ba-
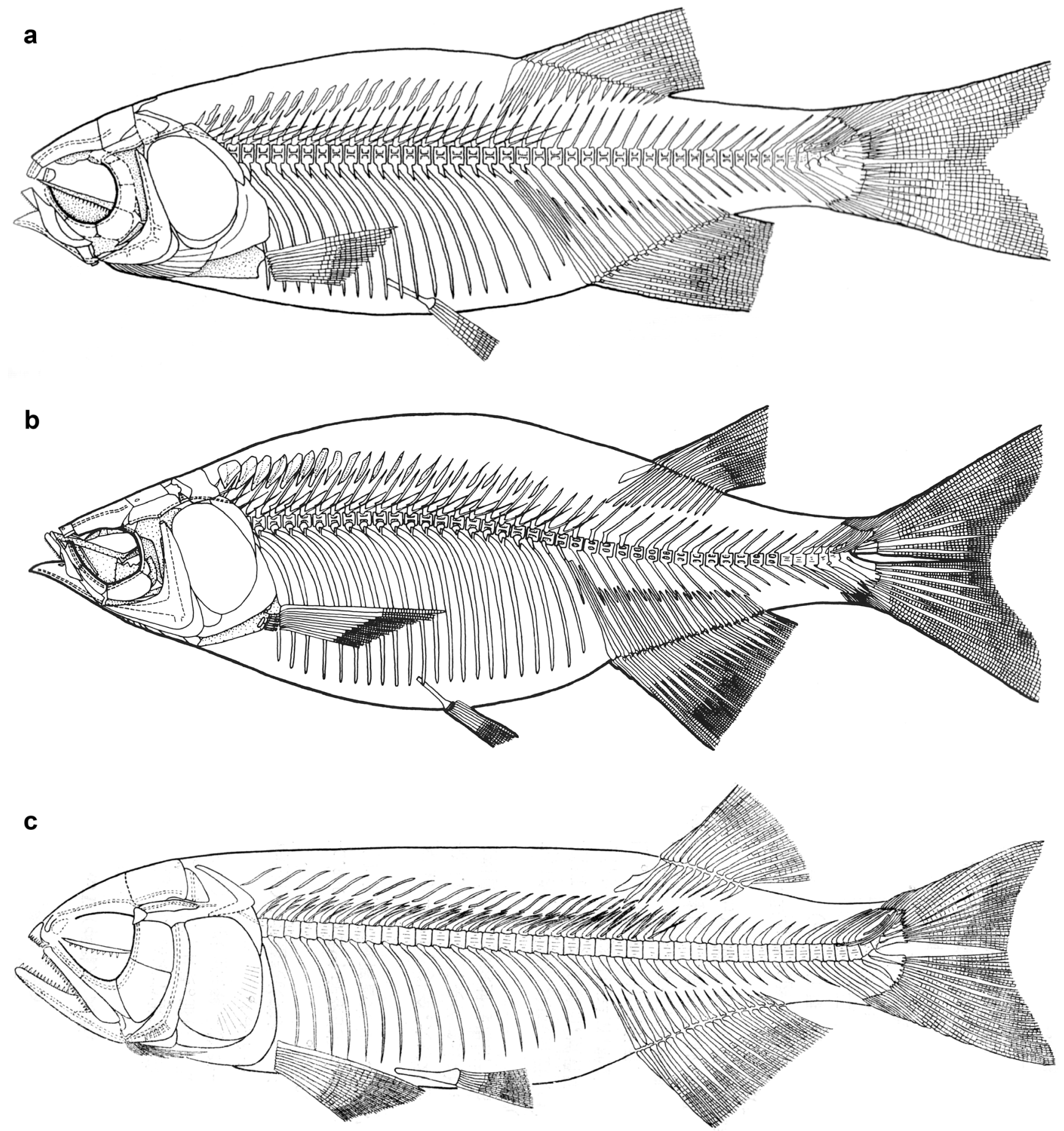

Fig. 2. Stem-group Osteoglossomorpha. Reconstructions of a. †Tongxinichthys microdus (modified from Zhang, Jin, 1999: fig. 2), b. $†$ Kuntulunia longipterus (modified from Zhang, 1998: fig. 11), and c. †Tanolepis ningjiagouensis (modified from Jin, 1991: fig. 1; note that †Tanolepis has been suggested to be a synonym of $\uparrow$ Paralycoptera). 
sed in part on preopercular and opercular shape; Li, Wilson, 1999). Similarly, $†$ Paralycoptera, from the Early Cretaceous (or possibly Late Jurassic as well; Tse et al., 2015) of China, was initially described as a member of $\dagger$ Lycopteriformes (Chang, Chou, 1977); †Tanolepis (Fig. 2c; Jin, 1991) is either a synonym (Jin et al., 1995; Xu, Chang, 2009) or sister-group (Li, Wilson, 1999) of $\uparrow$ Paralycoptera. Ma, Sun (1988) and Jin et al. (1995) suggested that it possessed reticulate scales, indicating an affinity to Osteoglossidae (although concluding that $\uparrow$ Paralycoptera was within crown Osteoglossidae, Zhang, 2006 noted differences in the details of the pattern of reticulation between the two groups). However, Xu, Chang (2009: figs. 8c,d) studied and illustrated very well preserved specimens that preserved the details of the scales, and show that these do not bear any furrows, but rather are large cycloid scales with fine circuli and a few radii (and are similar in overall form to the scales of Pantodon; Hilton, 2003: fig. 39d). Li, Wilson (1999) recovered it as sister to Osteoglossoidei (sharing similarities in the position and angle of the jaw and six hypurals), Zhang (2006) found it to be within crown-group Osteoglossidae (sister to Osteoglossinae $+\uparrow$ Phareodontinae; supported only by homoplasies), and Xu, Chang (2009), who found this genus to be intercalated between Mormyroidea and all fossil and living Osteoglossidae (sharing with the latter the condition of having the entire post- and suborbital region of the palatoquadrate covered by the infraorbitals). Wilson, Murray (2008; also Murray et al., 2010, 2018), in contrast, recovered $\uparrow$ Paralycoptera $+\uparrow$ Tanolepis as a stem group osteoglossomorph, just above the level of $\dagger$ Lycoptera. For details on the history of phylogenetic hypotheses for these and other stem-group osteoglossomorphs, including synapomorphies supporting the various hypotheses, the reader is referred to Shen (1996), Li, Wilson (1999), Zhang (2006), and Xu, Chang (2009). A full taxonomic and phylogenetic review, however, of many of these fishes, including those that were historically included in †Lycopteridae, is needed.

Hiodontidae. Hiodontidae (Fig. 3), which is regarded as the living sister group of all other extant Osteoglossomorpha (Taverne, 1979; Li, Wilson, 1996a; Hilton, 2003; Zhang, 2006; Wilson Murray, 2008), with one or two genera (Hiodon and $†$ Eohiodon); the fossil taxa †Yanbiania and $\dagger$ Jiaohichthys from the Early Cretaceous of China and $\uparrow$ Plesiolycoptera from the Mid Cretaceous of China are stem group Hiodontiformes. Hiodon comprises two extant species ( $H$. alosoides and $H$. tergisus), both found exclusively in the freshwater rivers and lakes throughout much of North America east of the Rocky Mountains. These fishes have a generalized, laterally compressed body, with large eyes, a forked caudal fin, and a silvery body with cycloid scales (Hilton et al., 2014). The parasphenoid and basihyal toothplate are armed with large, caniniform teeth that serve the so-called "parasphenoid-tongue bite apparatus" (Hilton, 2001). The osteology of Hiodon has been described by Taverne (1977) and Hilton (2002), with specific aspects of its skeleton described by others (e.g., caudal skeleton, Schultze, Arratia, 1988) due in part to its overall plesiomorphic morphology, which has led to its use as a representative basal teleost in broad based systematic analyses (see discussion and references by Hilton, 2002).

The three species of $\dagger$ Eohiodon from the Early Eocene of western North America have been regarded as close relatives of the extant genus Hiodon (Li et al., 1997a; Hilton, Grande, 2008; Fig. 3b). Indeed, because of the absence of any synapomorphies distinguishing the species of $\dagger$ Eohiodon from those of Hiodon, Hilton, Grande (2008) regarded it as a synonym of Hiodon. The two extant species of Hiodon possess a post-pelvic bone, and this is considered a synapomorphy of the extant taxa (Hilton, 2003), although the condition in most fossil taxa, including $\dagger H$. consteniorum and the species of $\dagger$ Eohiodon, is unknown (Hilton, 2003). Murray et al. (2010: fig. 10) illustrated a fragmentary bone that they interpreted as a postpelvic bone in $\uparrow$ Schuleichthys brachypteryx, a species from the Early Cretaceous of China that was left as incertae sedis at the base of Osteoglossomorpha. These authors suggested that the presence of a postpelvic bone in $\dagger$ Schuleichthys was a character of a broader group and therefore resurrected the genus $†$ Eohiodon (see also Murray et al., 2018). However, we find the published photograph documenting the postpelvic bone in $\uparrow$ Schuleichthys to be unconvincing, and maintain that until this element is clearly seen in taxa outside of the extant taxa, it should be considered to be a synapomorphy of these two extant taxa. Regardless, there has yet to be any synapomorphies identified that group the taxa previously included in the genus $\dagger$ Eohiodon (i.e., all diagnostic characters cited for the genus, such as low vertebral and fin ray counts, are plesiomorphic, being similar to stem group Hiodontiformes and †Lycopteridae). We therefore support the interpretation that those taxa previously included in $\uparrow$ Eohiodon should be regarded as stem group Hiodon (Hilton, Grande, 2008).

Notopteridae. The featherbacks, or Old World knifefishes, of the family Notopteridae comprise ten species in four genera distributed in the freshwaters of south and southeast Asia (Chitala, six species; Notopterus, one species; Fig. 4) and Africa (Papyrocranus, two species; Xenomystus, one species; Fig. 5) (Kottelat, 2013). The taxonomy of this family was revised by Roberts (1992), who noted that more material is needed to be examined from across the ranges of Notopterus and Xenomystus to better investigate the monospecific nature of these two genera. A single whole body fossil taxon ( $\uparrow$ Notopterus primaevus, from the Tertiary of Sumatra; Sanders, 1934) is known, but is in need of preparation and redescription. $\dagger$ Palaeonotopterus greenwoodi, from the Early Cretaceous of Morocco, was initially described based on isolated braincase and fragmentary skull bones (Forey, 1997, Taverne, Maisey, 1999) as a member of Notopteridae based on the presence of a supraorbital branch of the otic sensory canal, although this character was since identified in mormyroids (Cavin, Forey, 2001). Cavin, Forey (2001) con- 

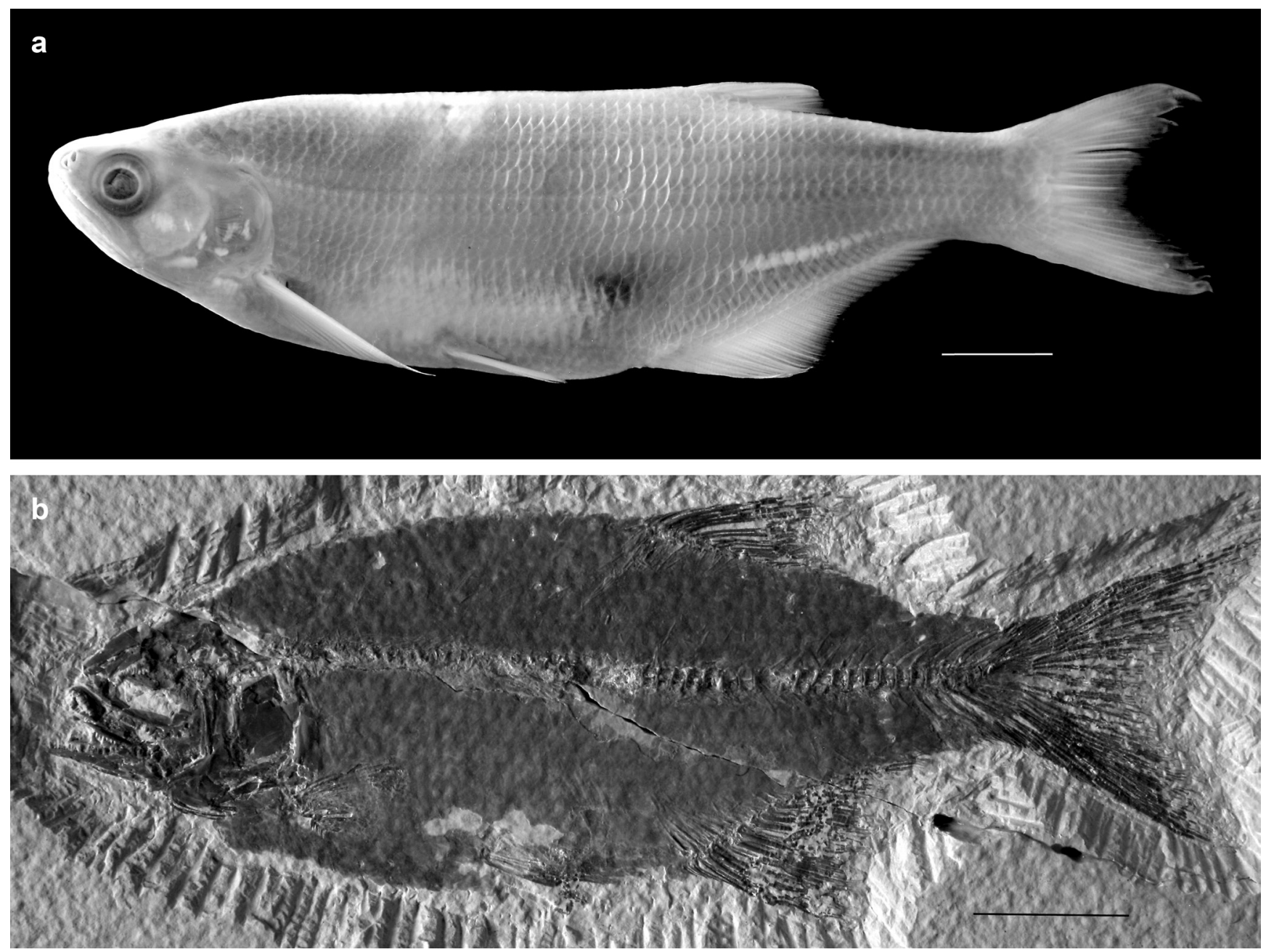

Fig. 3. Hiodontidae. a. Hiodon alosoides (VIMS 12099). b. † Hiodon falcatus, Eocene, Wyoming, USA (UMA F10651). Scale bars $=2 \mathrm{~cm}$.

sidered $\uparrow$ Palaeonotopterus greenwoodi to be either a stem notopterid or a stem mormyroid, and in subsequent phylogenetic analysis, it has been recovered as a stem group mormyroid (Hilton, 2003; Wilson, Murray, 2008). As noted by Cavin, Forey (2001), however, its anatomy is largely unknown and prevents confident phylogenetic interpretations.

All notopterids are extremely laterally compressed with an elongate anal fin that is confluent with the rounded caudal fin. The dorsal fin (absent in Xenomystus) has a short base but is tall and rounded. The body profile particularly that of Chitala, undergoes a dramatic ontogenetic change, in which there is a substantial dorsal concavity above the head in adult fishes (not evident in Notopterus or Xenomystus, and only slightly developed in Papyrocranus). All species have a series of small abdominal scutes formed by paired elements (Hilton, 2003: fig. 34). The species of Xenomystus and $\mathrm{Pa}$ pyrocranus are electroreceptive, whereas those of Notopterus and Chitala are not (Bradford, 1982).

Notopteridae is widely regarded as the sister group of Mormyroidea (= Mormyridae + Gymnarchidae) based on both morphological (Ridewood, 1904, 1905; Taverne, 1979;
Lauder, Liem, 1983; Li, Wilson, 1996a) and molecular data (Lavoué, Sullivan, 2004). Hilton's (2003) analysis resulted in a Notopteridae + Osteoglossidae clade, but he allowed that there were several characters that were not included in that analysis that supported the conventional grouping, as found in more recent phylogenetic analyses (Bonde, 2008; Wilson, Murray, 2008; Murray et al., 2010, 2018).

Mormyridae. By far Mormyridae is the largest family of Osteoglossomorpha. It has about 21 genera and well over 200 species (Fricke et al., 2018); the rate of new species descriptions in recent years suggests that there are far more to be discovered (e.g., a new genus, Cryptomyrus, was described recently from Gabon, suggesting that there are significant gaps in our knowledge of mormyrid diversity; Sullivan et al., 2016). All members of the family are found throughout Africa (except the Saharan, northern Maghreb, and southern Cape regions), and are particularly diverse in Central and West Africa (Stiassny et al., 2007). The earliest fossil remains of the family, comprising fragmentary skull bones, teeth, and isolated vertebrae, are Middle Pliocene 

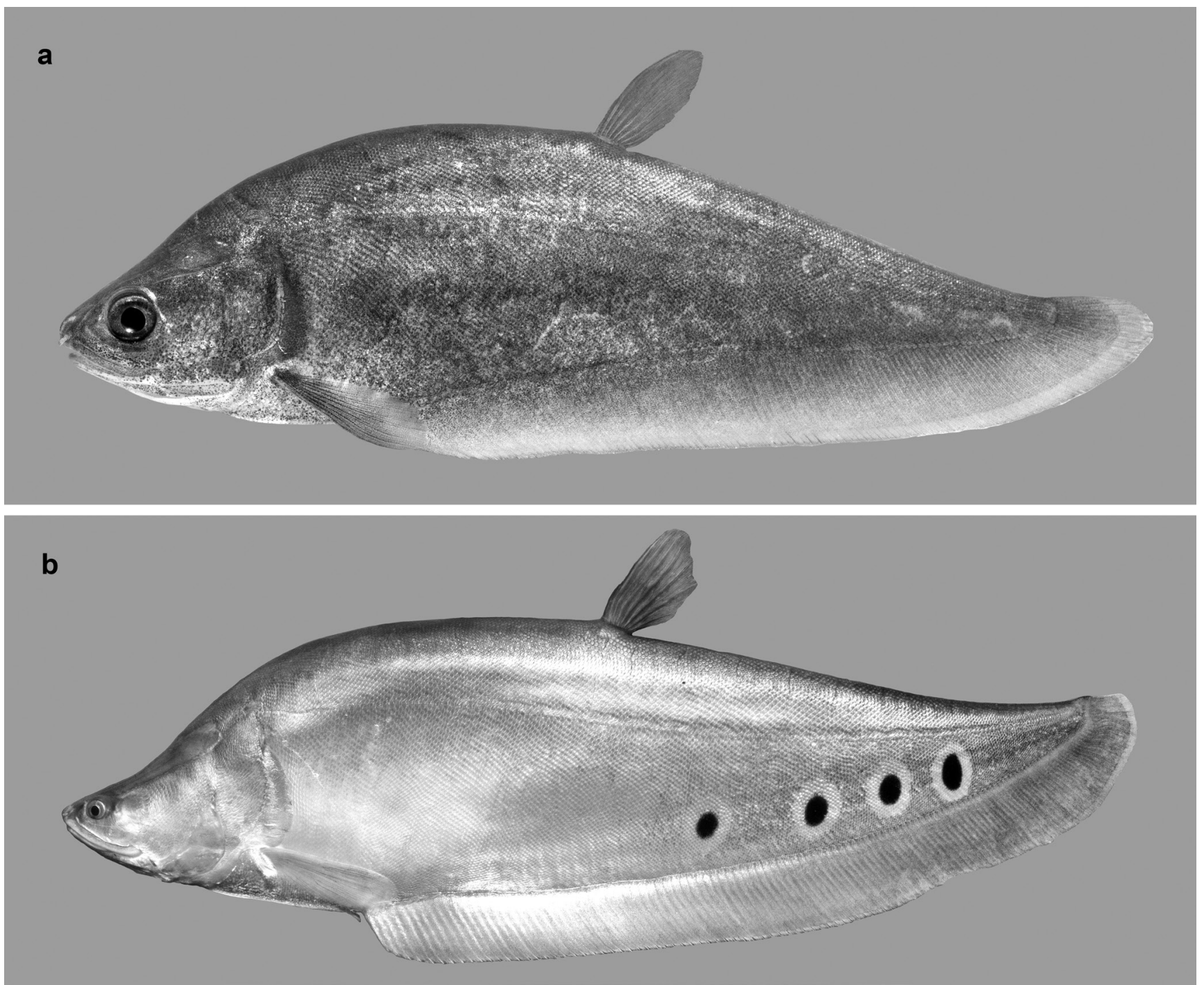

Fig. 4. Notopterinae. a. Notopterus notopterus (UF 237410; $167 \mathrm{~mm}$ SL). b. Chitala ornata (UF 237959; $498 \mathrm{~mm}$ SL). Photos by Z. Randall.

(Greenwood, 1972), although the family is very poorly represented in the fossil record. Hilton (2003) noted the irony of this, as this family is the most species rich in the extant fauna, but most other families have a much more temporally and taxonomically extensive fossil record. The diversity of the family, established in part by fast evolution of reproductive isolation caused by selection in mate recognition signals (i.e., electric organ discharges), is pronounced and the family has been cited as the only example of a freshwater species flock in a riverine (vs. lacustrine) system (Sullivan et al., 2002). All members of the family are weakly electric fishes, having both electroreceptors, and producing speciesspecific electric organ discharges for communication and localization purposes. There is great morphological diversity within this family in body form, but especially of their head shape, which ranges from blunt and rounded (e.g., Petrocephalus, Fig. 6a; Pollimyrus), to elongate, with a long snout and jaws (e.g., Gnathonemus and Campylomormyrus;
Figs. $6 \mathrm{~b}, \mathrm{c})$. The cranial diversity of certain taxa within the family, such as Campylomormyrus, has been suggested to reflect adaptive radiation driven by variation in diet (Feulner et al., 2007). Mormyridae (inclusive of Gymnarchidae; see below) all share an enlarged cerebellum, electric organs, electroreceptors, opercular bones covered by a thick fleshy flap, an intracranial diverticulum of the swim bladder, loss of the ventral hypohyal, absence of the basihyal and its toothplate, and features of the caudal skeleton (Boulenger, 1898; Taverne, 1972, 1979; Hilton, 2003).

The systematics of Mormyridae has not been investigated recently from a morphological perspective (see Future Research Needs, below). The most taxonomically rich data set to be analyzed to date is that of Sullivan et al. (2000), who investigated relationships among representatives of 18 genera and 41 species using mitochondrial (12S and 16S rRNAs, Cytochrome $b$ ) and nuclear (RAG2) loci. The results of this analysis are largely congruent with those of Taverne (1972) 

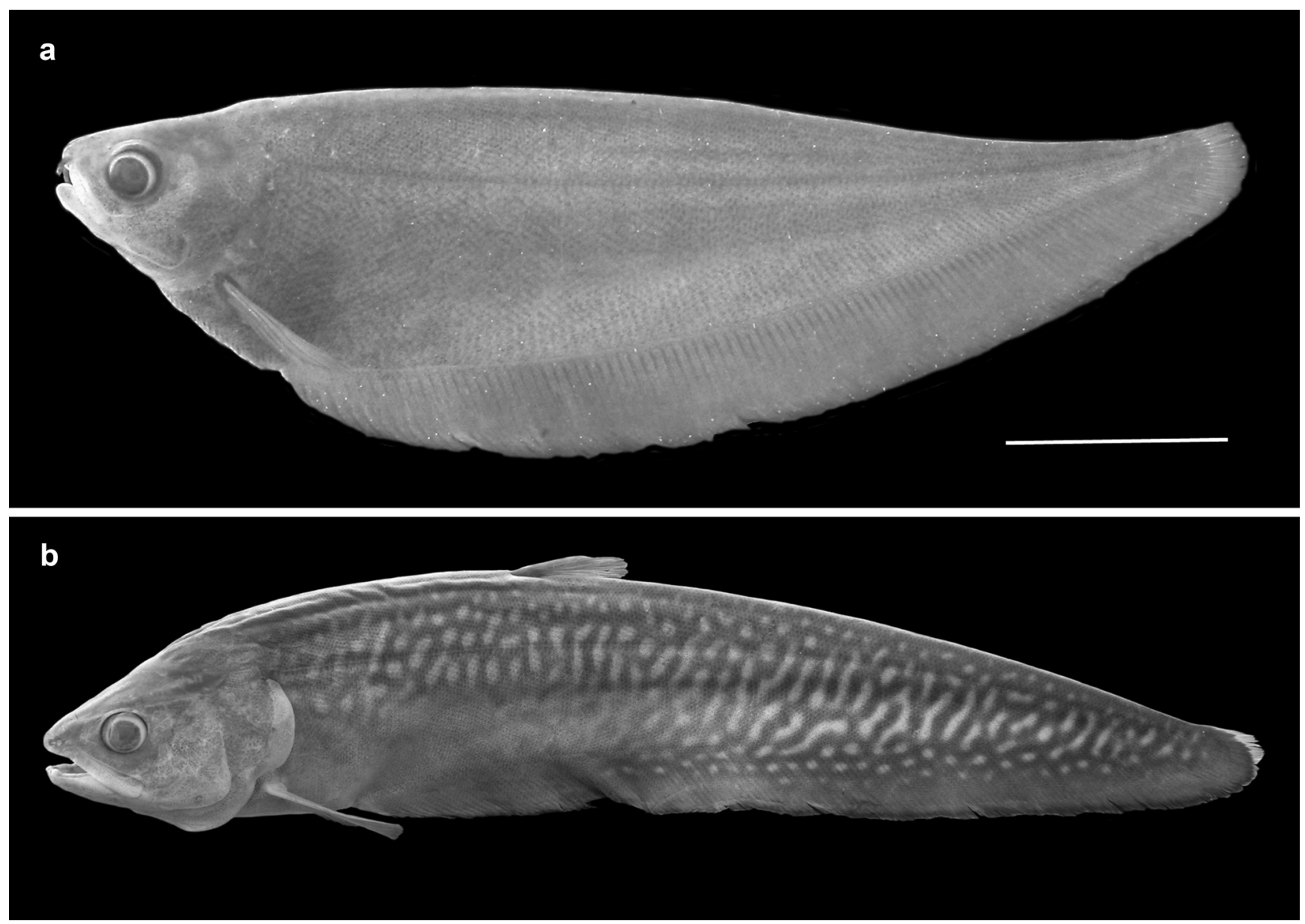

Fig. 5. Xenomystinae. a. Xenomystus nigri (CU 91453). b. Papyrocranus afer (CU 97661). Scale bars $=2 \mathrm{~cm}$.

at the higher taxonomical-levels, in that Gymnarchidae is its sister group, and the family can be divided into the Petrocephalinae (with only Petrocephalus) and Mormyrinae (all other genera). Within Mormyrinae, Myomyrus macrops, and Mormyrops spp. were recovered as successive sister groups to all other members of the subfamily. Notable results also included the non-monophyly of Brienomyrus, Pollimyrus, Marcusenius, and Hippopotamyrus. Based on this topology, the authors conclude that electrocytes with penetrating stalks is a derived conditions but they evolved early in the evolution of Mormyrinae; the electrocytes of Gymnarchus are stalkless (hypothesized to be the larval form of electrocytes found in Mormyridae) and those of Petrocephalus have non-penetrating stalks. There are several occurrences, presumably homoplastic, of reversal to the non-penetrating condition (e.g., within Brienomyrus, Paramormyrops, Marcusenius, and Campylomormyrus), although the taxon sampling in these genera was insufficient to draw firm conclusions of the number of reversals within Mormyrinae. Other previous phylogenetic studies, reviewed by Sullivan et al. (2000), include Agnèse, Bigorne (1992), Van der Bank, Kramer (1996), Alves-Gomes, Hopkins (1997), Alves-Gomes (1999), and Lavoué et al. (2000). Recent molecular phylogenetic studies of relationships of Mormyrinae include those of Sullivan et al. (2016) and Levin, Golubtsov (2018), and provide further evidence that the taxonomy and phylogeny of Mormyridae is far from settled.

Gymnarchidae. A single species, Gymnarchus niloticus, is included in this family (Fig. 7), and is found distributed throughout tropical Africa from Senegal to Ethiopia in the Ghazal and Jebel systems, White Nile, and Nile River to Lake Nasser (Sudan) in northeast Africa, and in the Gambia, Senegal, Niger, Volta, Ouémé and Chad rivers of western Africa (Azeroual et al., 2010). It has an elongate, cylindrical body with a broadly rounded head and a dorsal fin that runs most of the length of its body; anal, caudal, and pelvic fins are lacking. It reaches $1.67 \mathrm{~m}$ in length and $18.5 \mathrm{~kg}$ (Bigorne, 1990). Its osteology has been described by Taverne (1972), and aspects of its skeleton are illustrated by Benveniste (1994). Fossil remains identified as Gymnarchus are known from several localities throughout central and northern Africa (e.g., Pliocene deposits of Chad, Otero et al., 2009), including the Late Eocene Birket Qarun Formation in Egypt (Murray et al., 2010), which is the oldest record of the family.

Gymnarchidae is broadly considered to be the sister group of Mormyridae (Taverne, 1979, 1998; Bonde, 2008; classified as a subfamily of Mormyridae in some classifica- 

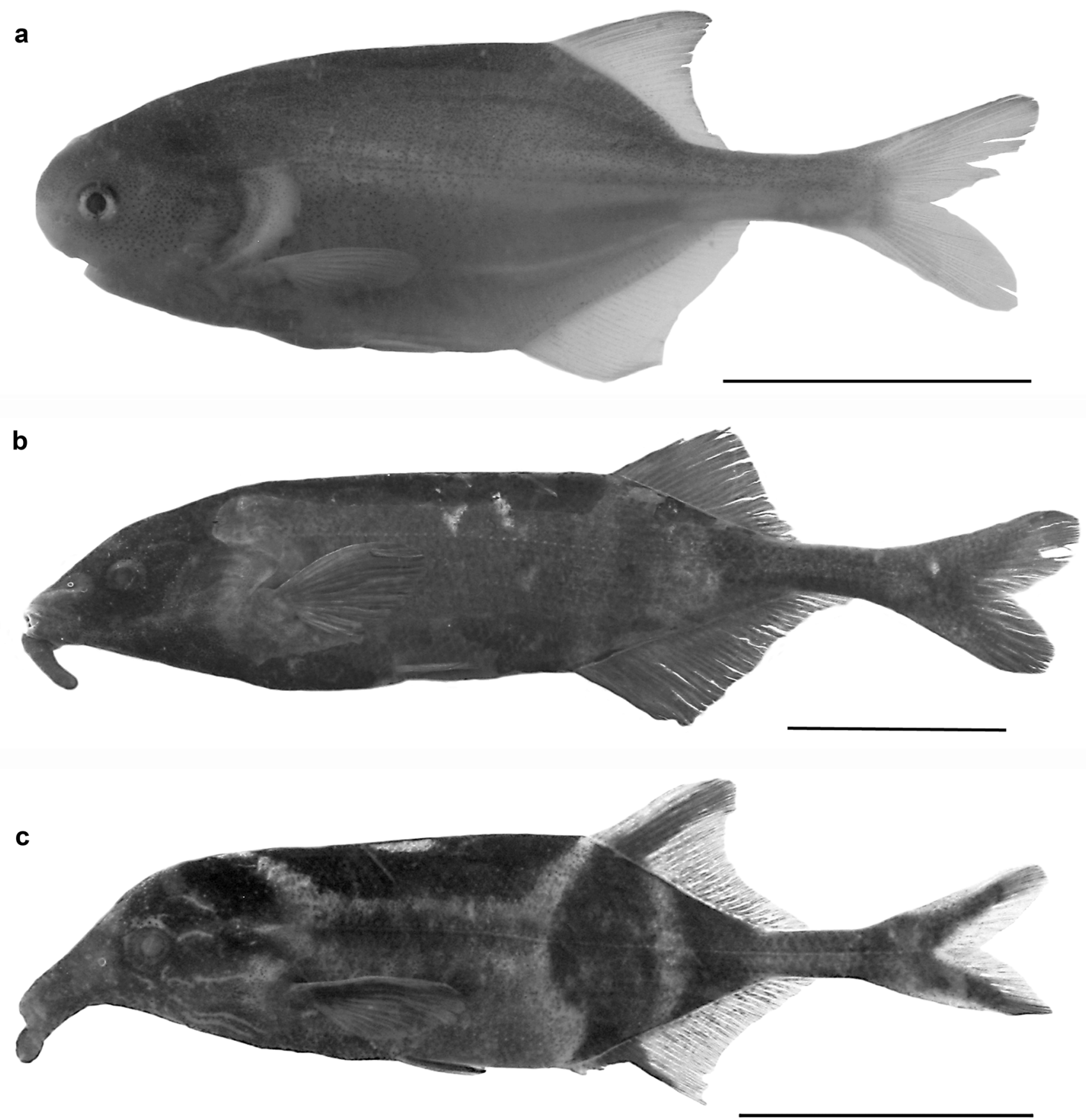

Fig. 6. Mormyridae. a. Petrocephalus bovei (CU 94594). b. Gnathonemus petersii (CU 91805). c. Campylomormyrus tamandua (CU 91801). Scale bars $=2 \mathrm{~cm}$.

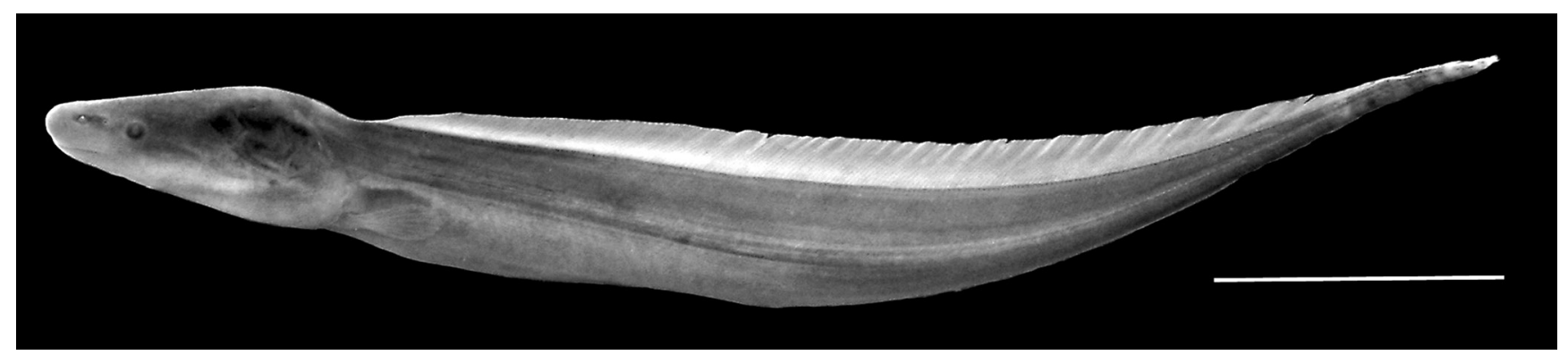

Fig. 7. Gymnarchidae. Gymnarchus niloticus (VIMS 22064). Scale bar $=2 \mathrm{~cm}$. 
tions, e.g., Greenwood, 1971; Lauder, Liem, 1983), although in most analyses and classifications it is not explicitly coded for, being subsumed into the supraspecific terminal group Mormyroidea (e.g., Li, Wilson, 1996a; Wilson, Murray 2008) or left uncoded (e.g., Hilton, 2003; Zhang, 2006). Although she did not designate it as a monotypic family, Benveniste (1994) recovered Gymnarchus as the sister-group of Petrocephalus + Mormyrinae. In this study, several unambiguous autapomorphies were identified distinguishing Gymnarchus from other mormyroids (absence of a supraoccipital crest, absence of basibranchial toothplates, absence of the first pharyngobranchial, absence of supraneurals, absence of the caudal fin, a dorsal fin with more than 100 fin rays, absence of an anal fin, a small posttemporal bone formed primarily by the ventral limb, the condition of having the $m$. posterior intermandibularis absent and the $m$. interhyoideus present); Gymnarchus also has an edentulous parasphenoid, although this is homoplastically found within Osteoglossomorpha in Heterotis and some mormyrids (Benveniste, 1994).

Osteoglossidae. Outside of Mormyridae, Osteoglossidae is the most diverse family of Osteoglossomorpha, with four extant genera, classified in two subfamilies (Osteoglossinae, including Osteoglossum from South America and Scleropages from Southeast Asia and Australia, and Arapaiminae (= Heterotidinae) including Heterotis from Africa and Arapai$m a$ from South America). In all osteoglossids, the large, cycloid scales are reticulate, with a network of furrows across the entire surface of the scales (mormyroids have reticulate furrows on just the posterior field of the scale, with welldeveloped radii on the anterior field; see Hilton, 2003: fig. 39). These furrows define so-called squamules, which have been recovered in the fossil record (Gayet, Meunier, 1983; Taverne et al., 2007). The crown-group osteoglossids have elongate, posteriorly positioned dorsal and anal fins (these are longer in Osteoglossum than in Scleropages), a short caudal peduncle, and a large rounded caudal fin.

Osteoglossinae (Fig. 8) have laterally compressed bodies and large, dorsally directed mouths with elongate lower jaws. Two barbels extend from the anterior tip of the lower jaws, and in life these are held horizontally in the water column. Most remarkably are the large pectoral fins that have a long, very robust leading pectoral fin ray. These fin rays support the strong pectoral fins that contribute to the ability of these fishes to float at the surface while hunting prey and leap from the water to capture terrestrial invertebrate and vertebrate prey items above the water line (Goulding, 1980; Verba et al., 2018). Adults of the two species of $O s$ teoglossum are silver $(O$. bicirrhosum) or greyish-steel $(O$. ferreirai) colored, the yolk-sac larvae of $O$. bicirrhosum are silver whereas those of $O$. ferreirai, which is restricted to the Rio Negro, are black with a distinct yellow lateral stripe on the body. The species of Osteoglossum are largely allopatric: O. bicirrhosum is found throughout the Amazon and the Branco river basins, and $O$. ferreirai is found in the Rio
Negro basin, including the Branco, and the Orinoco River, which was likely the result of an introduction (Escobar et al., 2013). Using a $\sim 1,000$ base-pair fragment of the mitochondrial genome, Escobar et al. (2013) calculated a genetic distance of $8.9 \%$ between the two species. Scleropages comprises four species, two from Southeast Asia (S. formosus from Vietnam, Cambodia, Thailand, the Malay Peninsula, Sumatra, and Borneo, and S. inscriptus from Myanmar) and two from Australia ( $S$. jardinii from the coastal river systems of northern Australia and Papua New Guinea, and $S$. leichardti from the Fitzroy River basin). Roberts (2012) suggested the subgenus name Delsmania Fowler, 1933 could usefully be applied to the group containing $S$. formosus and S. inscriptus, with the two Australian species being in the subgenus Scleropages. The four species of Scleropages have dramatic coloration and, at least in the case of $S$. inscriptus, patterning. Color variants oh $S$. formosus have been suggested to be distinct species (Pouyaud et al., 2003), although these are not regarded as valid (Kottelat, Widjanarti, 2005; Roberts, 2012). A fossil species of Scleropages, $\dagger$ S. sinensis, has been recently described from the Early Eocene Xiwanpu and Yangxi formations of China (Zhang, Wilson, 2017). Several additional fossil taxa have been interpreted as being close to Osteoglossinae, if not within the subfamily itself, including $\dagger$ Opsithrissops, $\dagger$ Brychaetus, $\dagger$ Foreyichthys, $\uparrow$ Heterosteoglossum (see Taverne, 1998; Bonde, 2008; and Forey, Hilton, 2010 for discussion of these and other fossil osteoglossid taxa). Although it bears an elongate lower jaw similar to that of osteoglossids, $\uparrow$ Furichthys, from the Early Eocene of Denmark, has been interpreted as stem-group Osteoglossi (= Osteoglossiformes + Mormyriformes; Bonde, 2008).

Arapaiminae comprises two genera of extant fishes (Arapaima and Heterotis; Fig. 9) and putatively several fossil taxa, including $\dagger$ Joffrichthys from the Paleocene of Canada (Li, Wilson, 1996b), $\dagger$ Trissopterus, from the Eocene of Italy, and $\dagger$ Sinoglossus from the Eocene of China (although see Murray et al., 2018, who found $\dagger$ Joffrichthys to be a potential stem osteoglossiform). Arapaima, because of the unique configuration of its occipital region (Hilton et al., 2007), has been identified in the fossil record based on isolated basiocciptal/vertebral elements (Lundberg, Chernoff, 1992; Gayet, Meunier, 1998). Arapaima has long been considered to be a widespread monotypic genus, with only $A$. gigas found throughout the Amazon basin. Stewart (2013a,b) argued that four nominal species and a new species should be recognized (A. arapaima, A. agassizi, A. mapae, A. gigas, and A. leptosoma). Stewart (2013a) further suggested that $A$. agassizi had no known specimens and had not been collected for 190 years, and that A. mapae and A. gigas were only known from their holotypes. Several studies have found moderate to low population genetic structure across the range of the genus at various scales (Araripe et al., 2013; Watson et al., 2013). Most range-wide structure appears to be associated with distance between populations (Hrbek et al., 2005), and low genetic diversity within smaller portions of its range is sugges- 

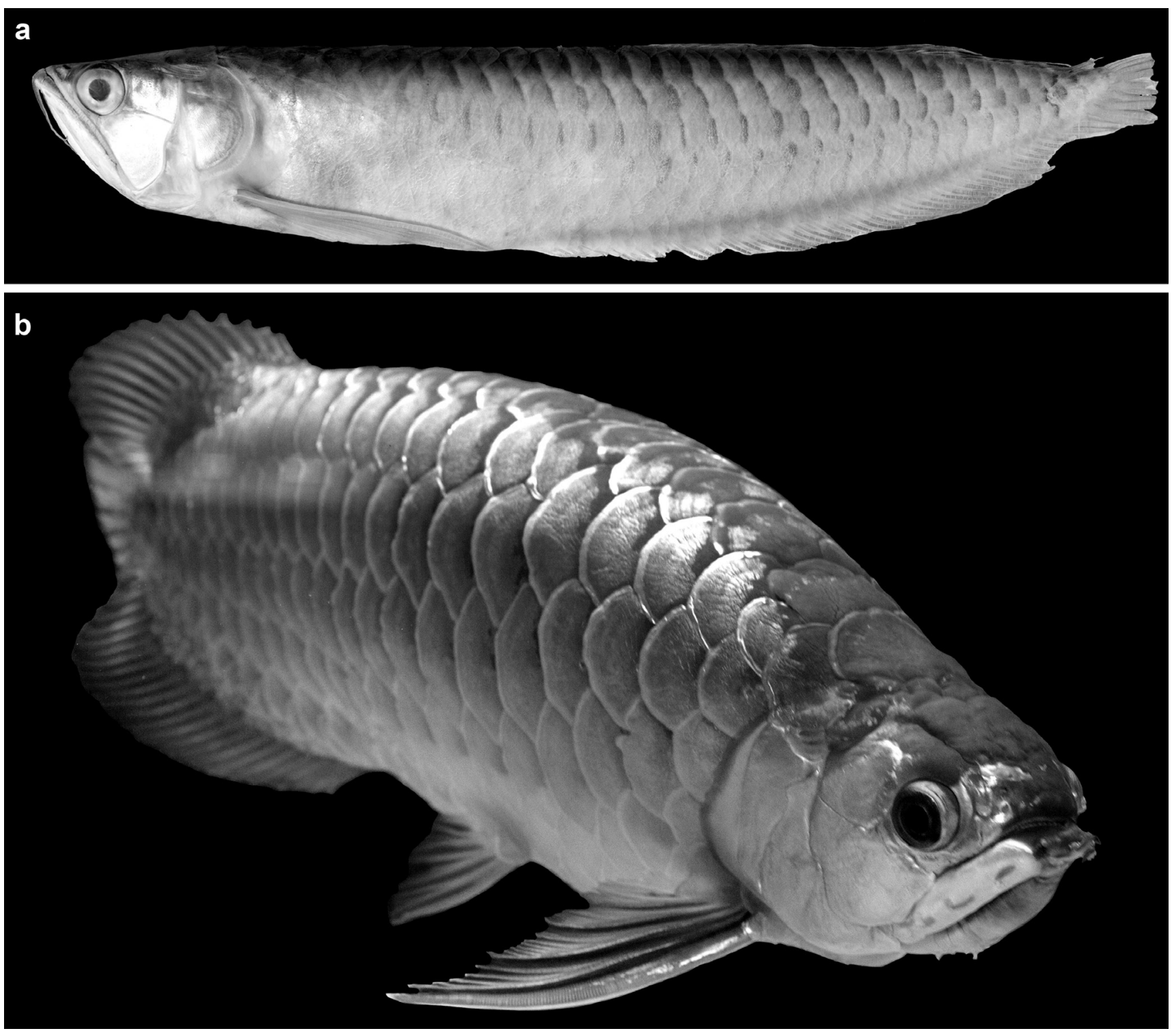

Fig. 8. Osteoglossinae. a. Osteoglossum bicirhossum (UF 189007; 260 mm SL; photo by Z. Randall). b. Scleropages formosus (aquarium specimen; photo by Z. Randall).

tive of overfishing (e.g., Araguaia-Tocantins basin; Vitorino et al., 2017). Heterotis niloticus is distributed throughout the Nilo-Sudanese region of Africa from Ethiopia to Senegal, the Chad basin, and Lake Turkana; it has been widely introduced in central and western Africa and is regionally extinct in the upper Egyptian Nile (Akinyi et al., 2010). In contrast to Arapaima, there is genetic structure of Heterotis, even within relatively small portions of their range (e.g., Hurtado et al., 2013, found significant genetic differentiation between three river basins in Benin). Arapaima and Heterotis are broadly regarded as sister taxa, supported by genetics and several morphological characters (enlarged first infraorbital bone, divided first infrapharyngobranchial, and having the angular, articular, and retroarticular all unfused in the adult [otherwise seen only in $\uparrow$ Phareodus]; Hilton, 2003).

As a taxonomic aside, Taverne (1979) named two sub- families of Osteoglossidae: $†$ Phareodontinae (including $\uparrow$ Phareodus, †Brychaetus, †Musperia, and $\uparrow$ Phareoides) and Osteoglossinae (including Osteoglossum and Scleropages), with Pantodontidae (only Pantodon) and Arapaimidae as separate families, and the latter containing the subfamilies Heterotinae (= Heterotis $+\uparrow$ Paradercetis) and Arapaiminae (= Arapaima). Two family group names for the clade including Arapaima and Heterotis have been used in the literature, Arapaimini Bonaparte, 1846 and Heterotidae Cope, 1871. Although the former has priority, the latter is in broad current usage, as Heterotidinae (e.g., Nelson, 1994, 2006; Li, Wilson, 1996a; Hilton, 2003; Nelson et al., 2016). However, the ICZN's (1999) criteria for reversal of precedence (Article 23.9) are not satisfied, as both family-group names have been used since 1899, and indeed Arapaimidae is also used in current literature (e.g., Taverne, 1998; Bonde, 

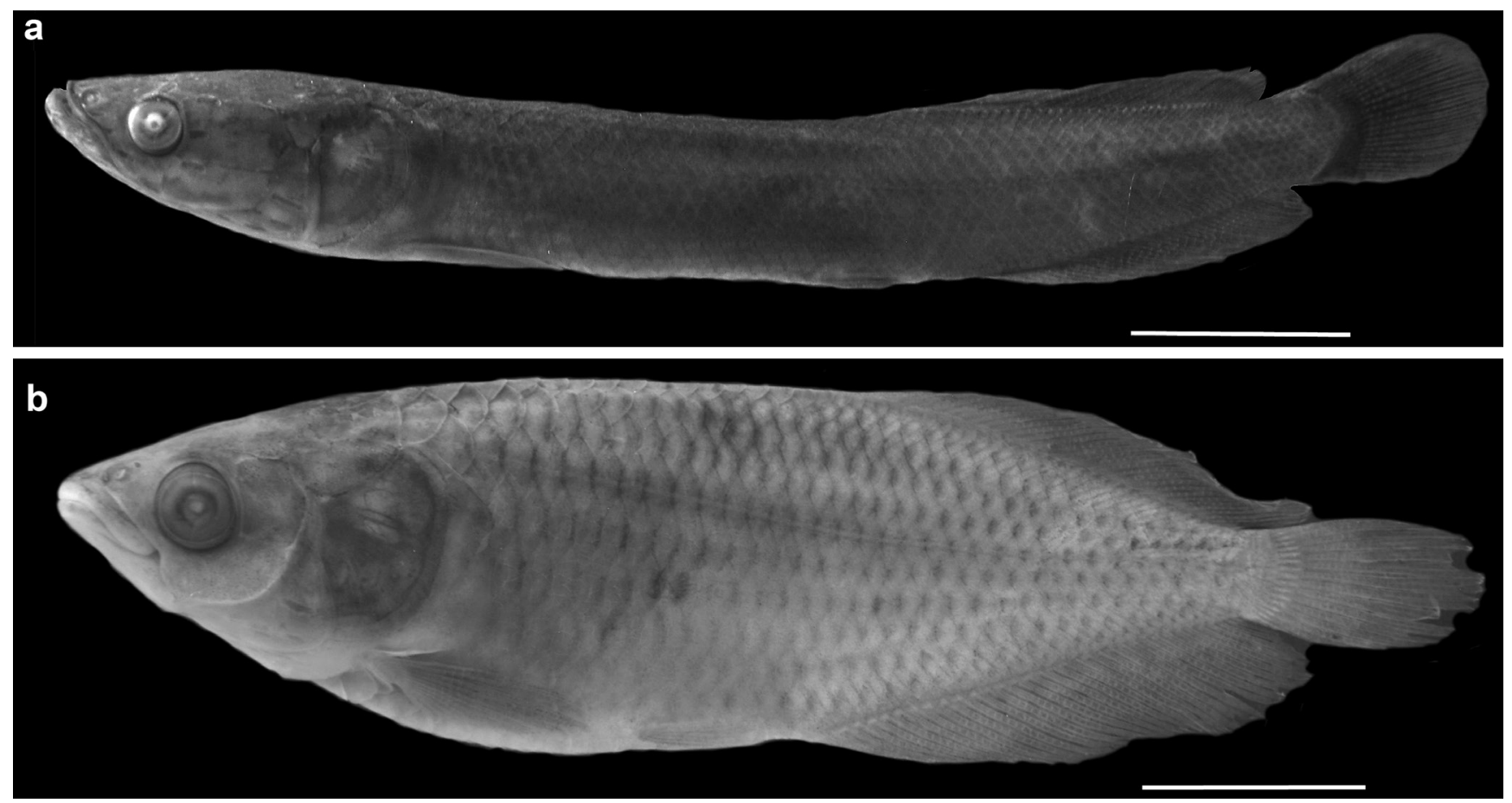

Fig. 9. Arapaiminae. a. Arapaima sp. (VIMS 38993; $120 \mathrm{~mm} \mathrm{SL}$ ). b. Heterotis niloticus (CU 95903); Scale bar = $2 \mathrm{~cm}$.

2008; Akinyi et al., 2010). Therefore, the principle of priority should prevail, and Arapaiminae is the correct name for this family-group taxon (van der Laan et al., 2014).

The genus-level diversity among the extant Osteoglossidae is dwarfed by the number of fossil genera included in or allied closely to the family (Forey, Hilton, 2010). Some of these taxa are insertae sedis, but several can be referred to the subfamily $\dagger$ Phareodontinae (Fig. 10), which was erected by Taverne (1979) to encompass $\uparrow$ Phareodus (Eocene, North America, Australia, including $†$ Phareoides), $\dagger$ Brychaetus, (Eocene, Europe, Africa, south Asia, and possibly North America), and $\uparrow$ Musperia (Eocene, Sumatra). To this group can be added $\dagger$ Cretophareodus, $\dagger$ Taverneichthys, and $\dagger$ Ridewoodichthys (e.g., see Kumar et al., 2005; Taverne, 2009a,b; Taverne et al., 2009; Forey, Hilton, 2010). Other taxa that are referable to the subfamily, or otherwise near its base (e.g., interpreted to branch off from the stem of the family, or crownward from the phareodontines) include $\uparrow$ Brychaetoides, $\uparrow$ Phareodusichthys, $\uparrow$ Monopteros, $\uparrow$ Xosteoglossid, $\uparrow$ Magnigena, and several unnamed taxa (Bonde, 2008; Forey, Hilton, 2010). Two Eocene osteoglossomorphs from Africa, $†$ Singida (Fig. 11) and $\dagger$ Chauliopareion, are frequently considered to be related to Osteoglossidae, primarily either as stem-groups (Murray, Wilson, 2005; Xu, Chang, 2009; Murray et al., 2018), or as sister-group to Pantodon (Hilton, 2003), although other positions have been supported (e.g., stem Osteoglossine, Zhang, 2006; stem Osteoglossi, Bonde, 2008). †Chanopsis (Aptian, Democratic Republic of the Congo) has also been considered to be an osteoglossid (Bonde, 1996; Taverne, 1998), although Forey, Hilton (2010) questioned this assessment.

A remarkable aspect of the fossil record of Osteoglos- sidae is that several forms are known from undisputedly marine deposits (Taverne, 1998; Bonde, 1996, 2008; Forey, Hilton, 2010). This is remarkable because all extant osteoglossomorphs are entirely freshwater forms, and their distribution has been held as a text-book example of vicariance biogeography. However, the occurrence of marine fossil taxa suggests that at least portions of the evolutionary history of Osteoglossomorpha took place in the marine realm (Taverne, 1998; Bonde, 2008; Forey, Hilton, 2010). Bonde (2008) in fact concluded a marine origin of Osteoglossomorpha, with two or three freshwater invasions, although as many as nine possible invasions into marine habitats was offered as an alternative hypothesis [this latter hypothesis was regrettably miscited as Bonde's primary conclusion by Forey, Hilton, 2010]). Among the marine forms are $\uparrow$ Magnigena (Paleocene, Saudi Arabia), $\uparrow$ Brychaetus (Eocene, Europe, Africa, south Asia, and possibly North America), $\uparrow$ Heterosteoglossum, $\uparrow$ Furichthys, $\uparrow$ Xosteoglossid, $\uparrow$ Brychaetoides, and an unnamed osteoglossiform (Early Eocene, Denmark), $\dagger$ Monopteros, $\dagger$ Thrissopterus, and $\dagger$ Foreyichthys (Eocene, Monte Bolca, Italy), as well as several unnamed taxa (e.g., a particularly osteoglossid-like partial braincase from the Eocene London Clay; Forey, Hilton, 2010).

Pantodontidae. A single species comprising genetically differentiated allopatric populations, Pantodon buchholzi, the African butterfly fish, is classified in the family Pantodontidae (Nelson et al., 2016), although it is frequently included within the family Osteoglossidae (e.g., Taverne, 1979; Li, Wilson, 1996a; Hilton, 2003). This is a relatively small fish, with a strongly upturned mouth, flattened head, 

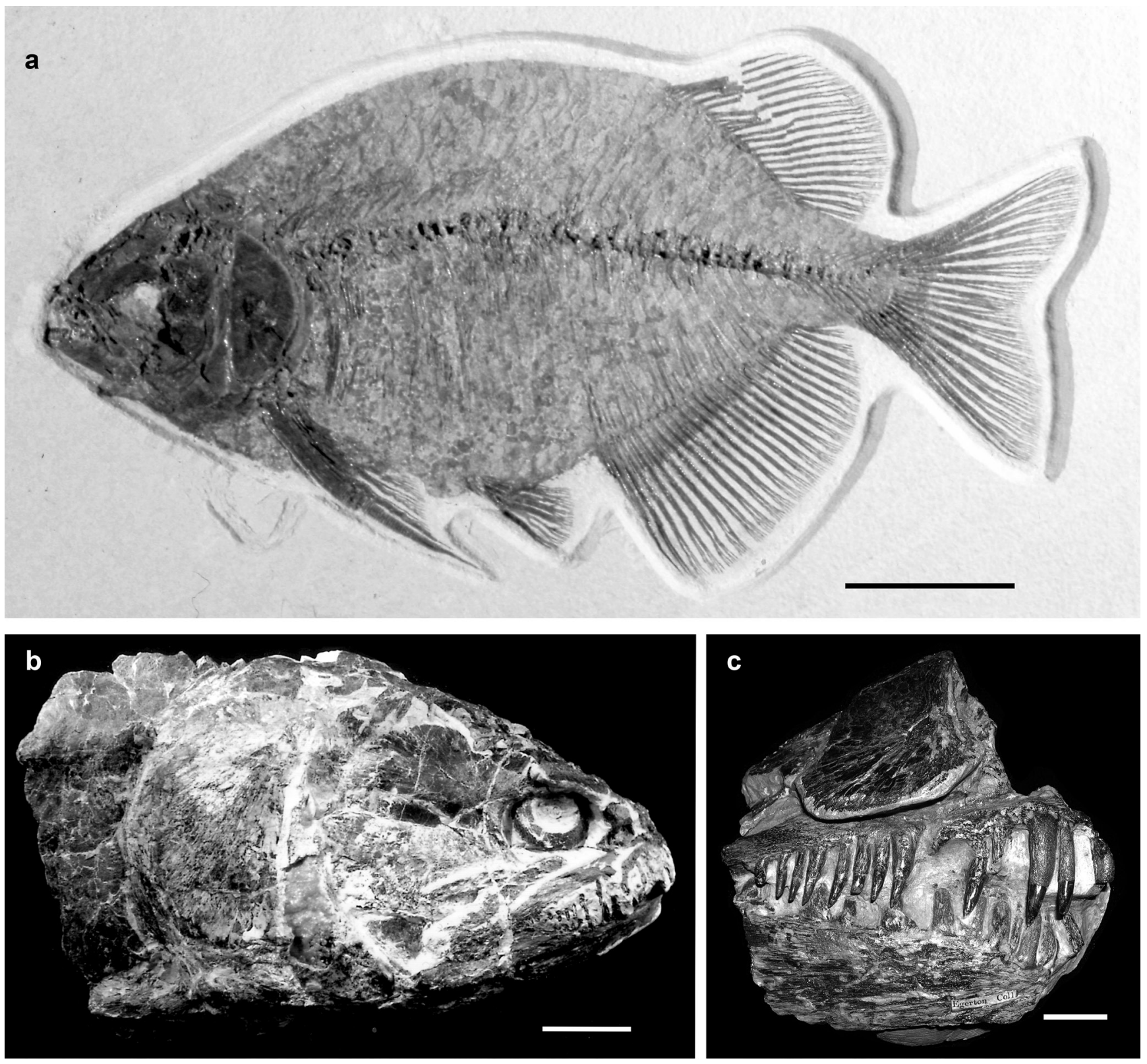

Fig. 10. $\uparrow$ Phareodontinae. a. $\uparrow$ Phareodus testis, Eocene, Wyoming, USA. (UMA F11332; scale bar $=2 \mathrm{~cm}$ ). b. $\uparrow$ Brychaetus muelleri (BMNH P3898; holotype; scale bar $=5 \mathrm{~cm}$ ) and $\mathbf{c} . \dagger$ Brychaetus muelleri $(\mathrm{BMNH} 1748$; scale bar $=2 \mathrm{~cm})$, Eocene, England.

short dorsal and anal fins positioned far back on its body, a rounded caudal fin, large wing-like pectoral fins, and pelvic fins with an elongate fin rays (Fig. 12). The head and pectoral fin has a superficial similarity to that of osteoglossines. Despite its similarity in some respects (e.g., infraorbital bones) to Osteoglossinae, Nelson (1969: 25) observed that "the systematic position of Pantodon consequently is obscure." This remains to be the case (see below). Part of the issue with the systematic placement of Pantodon is that it is a highly derived taxon, with numerous autapomorphies as well as significant character conflict with other osteoglossomorphs. For instance, the absence of a symplectic is shared with Mormyroidea, whereas the absence of an autopalatine is shared with Osteoglossidae (Moritz, Britz, 2005). However, unlike those of osteoglossid conditions, the scales of Pantodon lack reticulations (e.g., Hilton, 2003: fig. 39) and Pantodon has two gonads (versus one) (Britz, 2004).

The skeletal anatomy of Pantodon has been described and illustrated by Taverne (1978), and portions of its skeleton was illustrated and described by Hilton (2003) and Hilton, Britz (2010). In a study of its development, Moritz, Britz (2005) showed that the single dermal bone of the palatoquadrate in the adult of Pantodon is an ontogenetic fusion of the dermopalatine and ectopterygoid. They further conclude that the basipterygoid articulation found in Pantodon and Osteoglossidae is structurally homologous to that found 


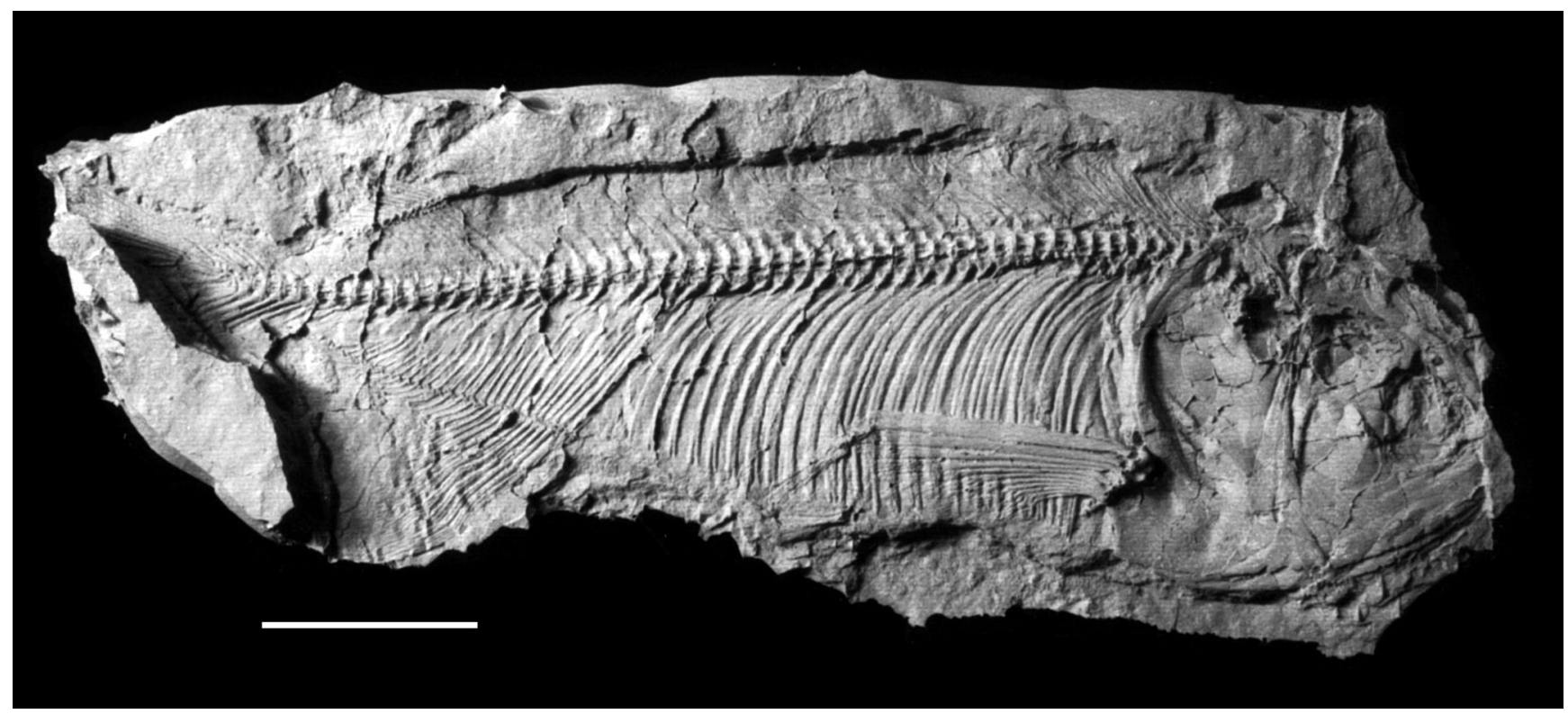

Fig. 11. †Singida jacksonoides (BMNH P63333, latex peel of holotype). Scale bar $=2 \mathrm{~cm}$.

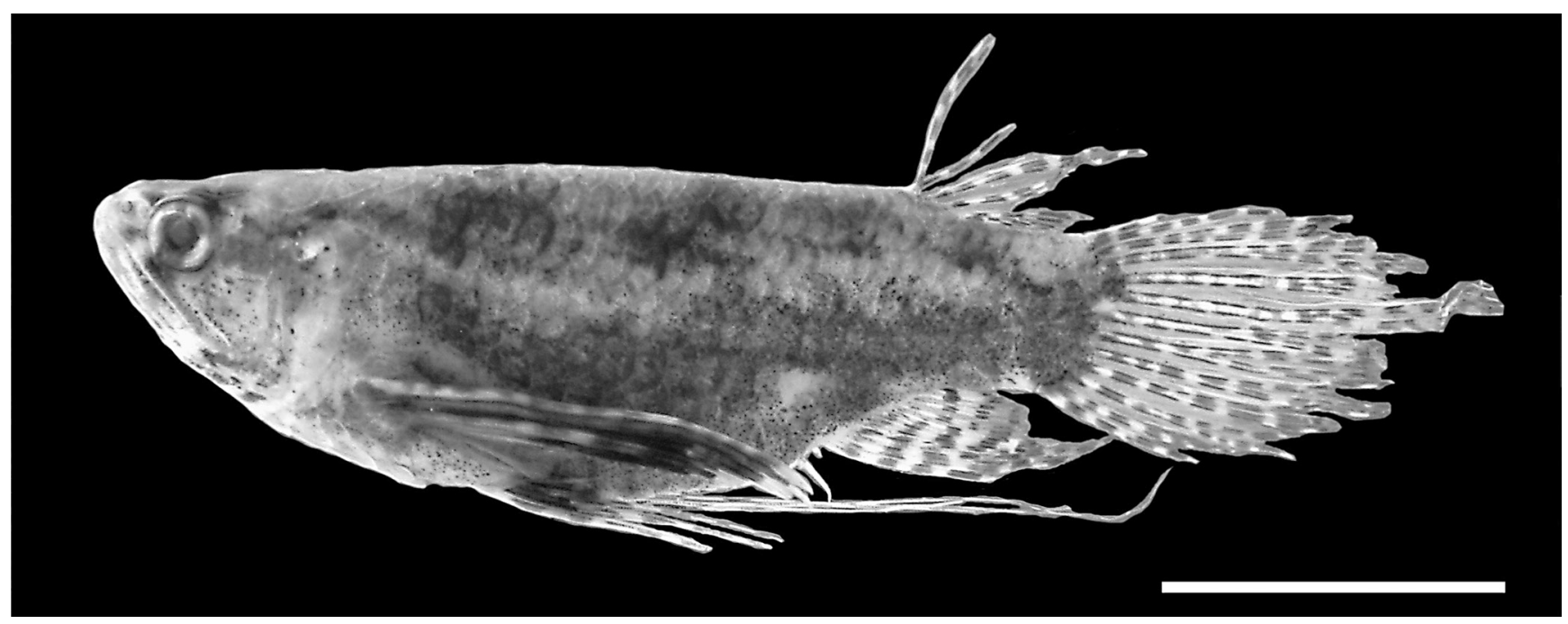

Fig. 12. Pantodontidae. Pantodon buchholzi (CU 87447). Scale bar $=2 \mathrm{~cm}$.

in non-teleosts and a basal clupeomorph, and therefore is a character at a broader level of phylogeny than uniting a subgroup of osteoglossomorphs (e.g., Greenwood et al., 1966; Lauder, Liem, 1983; Arratia, Schultze, 1991).

\section{Systematic Biology of Osteoglossomorpha}

Morphological systematics of osteoglossomorph fishes. Although there is broad agreement that there are three primary groups at the base of crown-group Teleostei (i.e., Osteoglossomorpha, Elopomorpha and Clupeocephala), their interrelationships have been debated. The two primary hypotheses based on morphological data are alternatively that Osteoglossomorpha or Elopomorpha holds the basal position, with the other resolved as sister group to Clupeocephala. The hypothesis that Osteoglossomorpha is the sister group of all other living Teleostei is supported by elopomorphs and clu- peocephalans having a reduced number of uroneurals that extend anteriorly beyond the second ural centrum (two versus three or four, as found in Hiodon), and in having epipleural bones throughout the abdominal region (Patterson (1977; also Patterson, Rosen 1977). In contrast, basal members of Elopomorpha retain a broad suite of plesiomorphies (e.g., a gular plate, a suprapharyngobranchial bone, mandibular sensory canal that open posteriorly or medially, and the antorbital bone carry the infraorbital canal) such that the alternate state of these characters resolve as synapomorphies for Osteoglossomorpha + Clupeocephala (e.g., Arratia, 1991, 1997, 1999; Li, Wilson, 1996a; Shen, 1996).

Taverne's (1979) analysis of osteoglossomorph relationships set the stage for all subsequent studies of the interrelationships of the group. The topology of extant taxa reflects that which is recovered in most other studies (with 
the exception of the position of Pantodon in molecular analyses; see below), with Hiodontidae as sister group of all other osteoglossomorphs, Notopteridae and Mormyroidea as sister groups, and three lineages within Osteoglossidae (Osteoglossum + Scleropages, Arapaima + Heterotis, and Pantodon). Notable in this analysis was the inclusion of many fossil taxa, particularly those from Africa and Monte Bolca (Italy), which have been rarely included in more recent analyses (e.g., †Chetungichthys, $\dagger$ Kipalaichthys, $\dagger$ Paradercetis, $\dagger$ Foreyichthys, $\dagger$ Opsithrissops, $\dagger$ Monopteros, and $\uparrow$ Musperia). Some of these are represented by few, fragmentary or poorly preserved specimens, and their systematic affinities have been discussed by other authors. Taverne (1998; Fig. 13a) revisited the systematics of Osteoglossomorpha following his redescription of several osteoglossomorph taxa from Monte Bolca. This new analysis defined 333 characters (some of which appear at multiple times or as reversals at different levels of phylogeny), and expanded the taxon sampling, in part by evaluating individual species (e.g., species of $\dagger$ Phareodus). Unsurprisingly, the position of many of the fossil taxa moved around compared to his 1979 analysis (which had left several relationships ambiguous), including dissolution of $\dagger$ Phareodontinae, the members of which spread out along the backbone of the tree within Osteoglossiformes. In the context of analyzing the systematic affinities of new marine fossil osteoglossomorphs from the Eocene of Denmark, Bonde (2008) critically examined the phylogeny of Osteoglossomorpha as a whole. The discussion, which weighed character data from Taverne (1998) and Hilton (2003), with the resulting classification (Fig. 13b) largely consistent with the phylogeny proposed by Taverne (1998), with differences among some fossil taxa (e.g., $†$ Foreyichthys).

In a series of studies on fossil and living osteoglossomorphs, Li and colleagues (Li, Wilson, 1996a,b, 1999; Li et al., 1997a,b; Fig. 14a) made the first attempts to incorporate data for osteoglossomorphs into a global, computer-assisted parsimony analysis, and this data matrix has served as the basis for all subsequent study of the group. In particular, these studies included data for an expanded taxon sampling, which included several of the fossil taxa from the Cretaceous of China (e.g., $\uparrow$ Tongxinichthys, $\uparrow$ Yanbiania, $\uparrow$ Plesiolycoptera, $\uparrow$ Paralycoptera, $\dagger$ Kuntulunia, etc.). The basic framework of the topology is similar to that presented by Taverne (1979) for the extant taxa. Hilton (2003; Fig. 14b) reevaluated the characters used in Li's analyses and discovered errors of coding and criticized aspects of their character definition. In Hilton's (2003) results, the major difference was in the position of Notopteridae (as sister group of Osteoglossidae + Mormyroidea, instead of sister to Mormyroidea). Although Osteoglossidae + Mormyroidea was supported by several uniquely derived characters (e.g., extrascapular reduced and irregularly shaped, fifteen or fewer branched caudal fin rays, and one neural spine on ural centrum 1), several characters that support Notopteridae + Mormyroidea could not be fully evaluated in that study. Zhang (2006) and Xu, Chang (2009) further examined the systematic relationships of Osteoglossomorpha, based in part on a new study of several of the early osteoglossomorphs from the Early Cretaceous of China. Both are consistent with relationships among extant taxa, with the exception of the position of Pantodon, which Zhang (2006) found to be the sister group of Osteoglossinae (vs. sister to Osteoglossidae).

Wilson, Murray (2008) also reviewed the relationships within Osteoglossomorpha, accepting some of Hilton's (2003) characters and interpretations, and rejecting others to return to Li et al. (1997b; the most recent of data sets, despite publication dates). The resulting topology again, provided consistent results regarding the relationships of extant taxa (including return of the traditional Notopteridae + Mormyroidea clade, contra the results of Hilton, 2003). This data matrix has been expanded by coding of newly described fossil taxa (e.g., †Chauliopareion, $\dagger$ Wilsonichthys, $\dagger$ Shuleichthys, $\dagger$ Lopadichthys), and the most recent iteration appears in Murray et al. (2018; Fig. 14). That study described a new species of $\dagger$ Joffrichthys $(\dagger J$. tanyourus), a new genus and species (†Lopadichthys colwellae) and reviewed the fossil record of osteoglossomorphs in North America. Notable among its results is the exclusion of $\dagger$ Joffrichthys from the Osteoglossidae. The authors also convincingly justified removal of $\dagger$ Ostariostoma wilseyi, a monotypic genus from the Late Cretaceous or Early Paleocene of Montana, from Osteoglossomorpha, where it had been assigned since Grande, Cavender's (1991) redescription. †Ostariostoma has long been regarded as a problematic taxon, of unstable relationships, and Murray et al. (2018) suggest that it might be allied to Gonorynchiformes, citing similarities of the vertebral column of these fishes. A further result of this study is the demonstration of just how sensitive the data matrix is to changes in coding, as with both changes in taxon sampling (e.g., expansion of outgroups to include Amia and taxa from Clupeomorpha, and removal of $\dagger$ Ostariostoma) and slight changes to homology assessment (e.g., identification of epurals and uroneurals in fossil taxa) and the resulting coding changes, produce very different phylogenies, including the non-monophyly of Osteoglossomorpha. This suggests that many of the nodes are weakly supported and/or that many taxa contain substantial suites of conflicting characters.

Molecular systematics of osteoglossomorph fishes. The molecular systematics of osteoglossomorph fishes have focused primarily on three main questions relative to its monophyly, its phylogenetic position within Teleostei, and the inter-familial relationships within the order Osteoglossiformes (i.e., Osteoglossomorpha excluding the order Hiodontiformes). In addition to these higher-taxonomic level studies, several molecular studies have inferred the phylogeny of each osteoglossomorph family, often to examine either the evolution of some of their most remarkable traits or their geographical distribution or their evolutionary processes. The molecular systematics of Osteoglossomorpha is slowly 
a Taverne (1998)

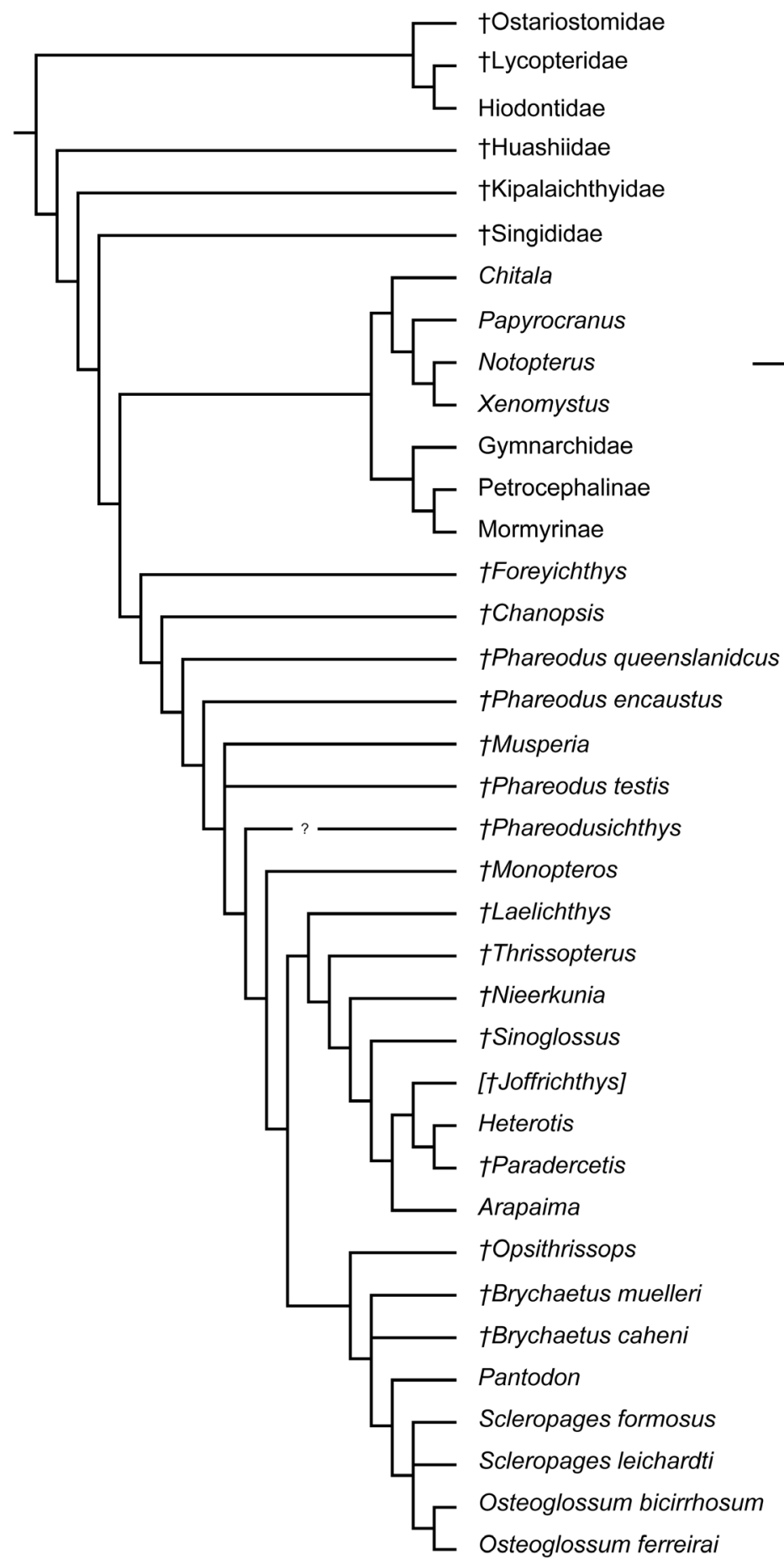

b Bonde (2008)

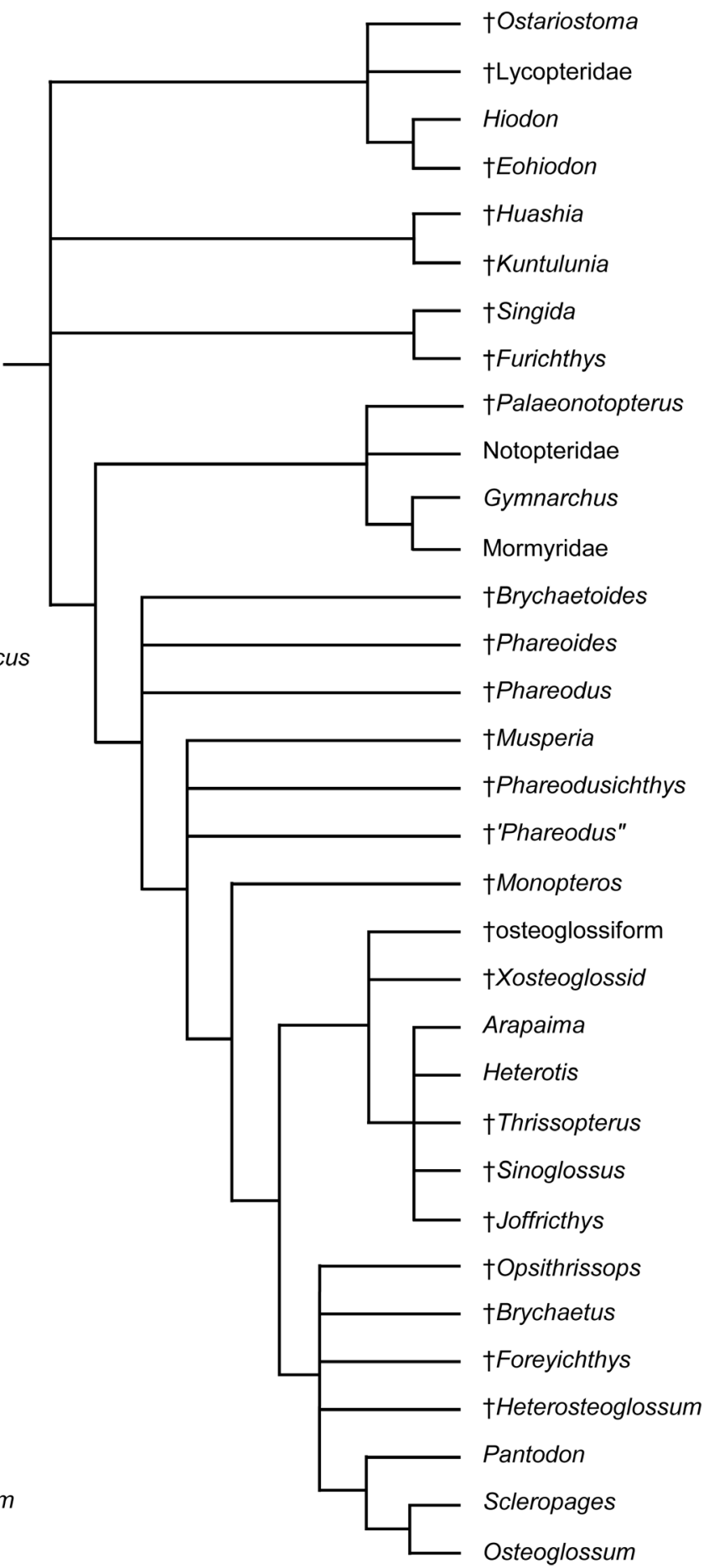

Fig. 13. Morphological systematics of Osteoglossomorpha. Phylogenies redrawn from a. Taverne (1998) and b. inferred phylogeny based on classification presented by Bonde (2008).

entering in a new area, the "genomic area", thanks to the development of molecular biology technology making it possible to sequence complete genomes at a reasonable cost and the progresses in computer sciences making possible to compare such large genomic data. In this section, we review these aspects of the systematics of Osteoglossomorpha.
Monophyly of Osteoglossomorpha. The monophyly of living Osteoglossomorpha is strongly supported by several morphological synapomorphies (see above), and this hypothesis therefore represented a good test to evaluate the value of molecules in systematics of Osteoglossomorpha. Only few molecular studies comprehensively tested the monophyly 
a Li \& Wilson (1996a)

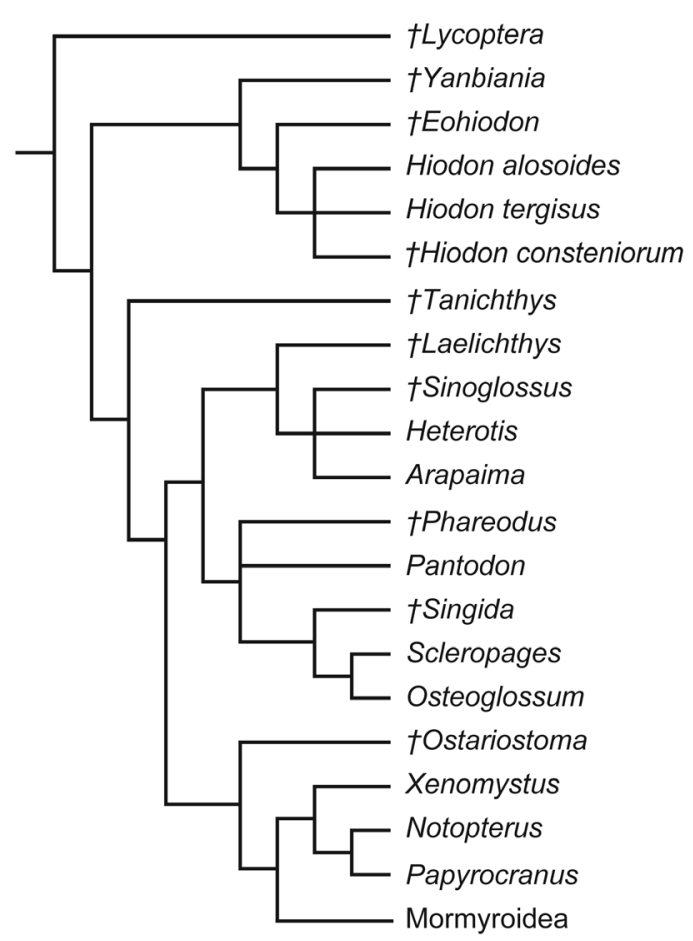

C Zhang (2006)

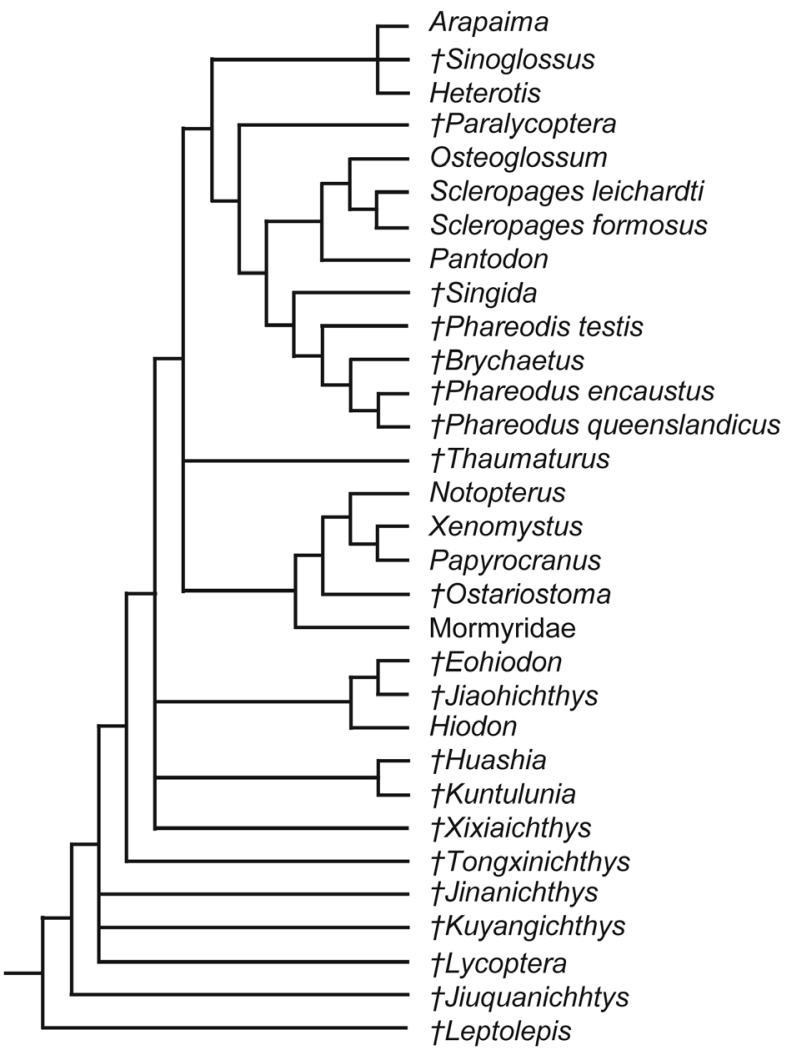

b Hilton (2003)

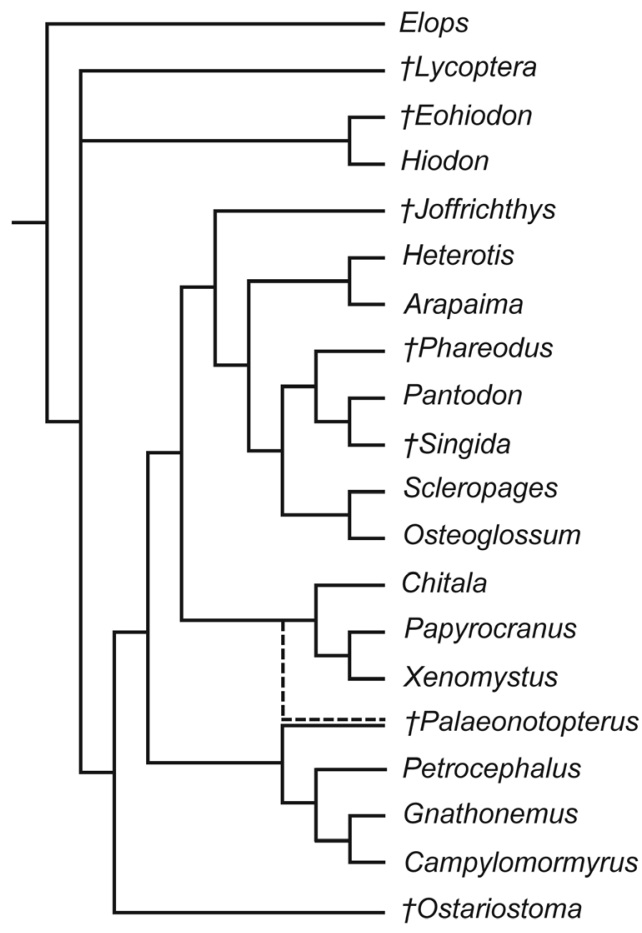

d Murray et al. (2018)

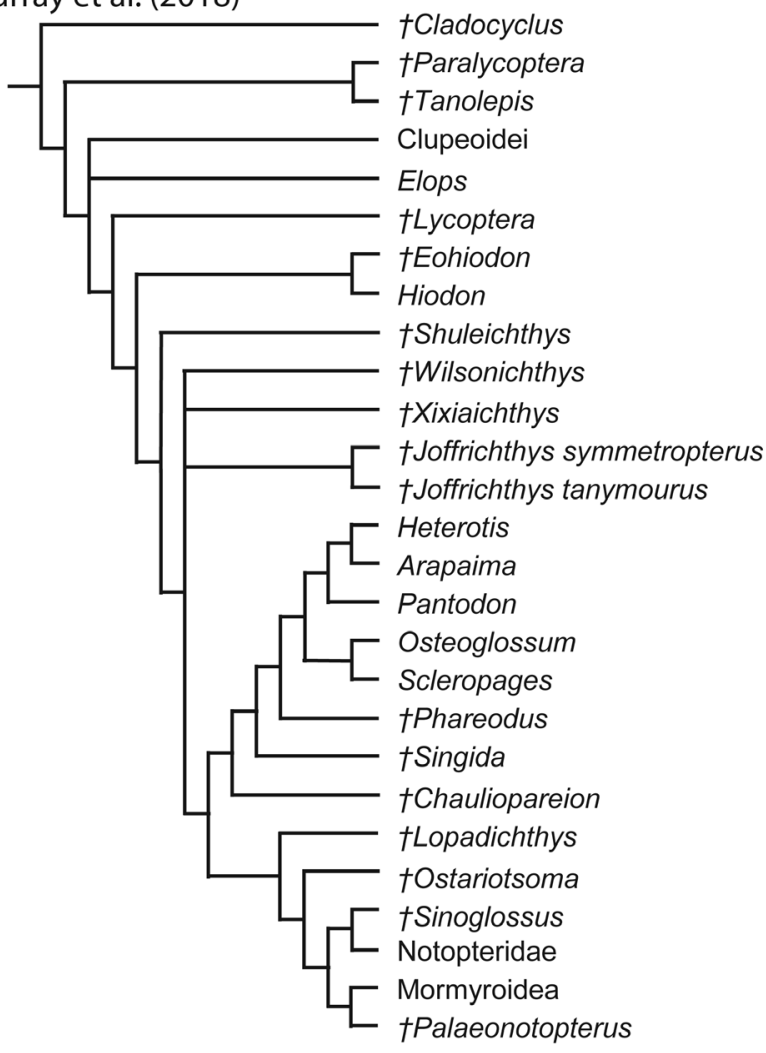

Fig. 14. Morphological systematics of Osteoglossomorpha. Phylogenies redrawn from a. Li, Wilson (1996a), b. Hilton (2003), c. Zhang (2006), and d. Murray et al. (2018). 
of Osteoglossomorpha by including at least one species of Hiodon and one species of Osteoglossiformes, along with at least one representative of Elopomorpha, one representative of Clupeocephala and one non-teleost ray-finned fish (such as Amia calva) to root the tree. All these studies recovered a monophyletic Osteoglossomorpha with strong statistical support, using either complete mitogenomes (e.g., Inoue et al., 2003; Lavoué et al., 2012) or large selections of nuclear genes (Near et al., 2012; Betancur-R et al., 2013).

Phylogenetic position of Osteoglossomorpha. Since the first (i.e., early 1990s) nucleotide sequence-based studies aiming to investigate the relationships among main teleost lineages, Osteoglossomorpha, Elopomorpha (eels and relatives), Clupeomorpha (sardines, anchovies and relatives), Ostariophysi (milkfish, carps, catfishes, and relatives) and Euteleostei (salmons, pikes, spiny-fishes and relatives) (i.e., Normark et al., 1991; Le et al., 1993), several molecular studies have addressed the question of the phylogenetic position of Osteoglossomorpha relative to other teleosts using larger molecular datasets and denser taxonomic samplings. The topologies of the phylogenetic trees of Normark et al. (1991) and Le et al. (1993) were different from each other and also contained some unconventional groupings that were likely the consequence of sparse taxon samplings and short molecular sequences used in these two exploratory molecular studies. However, despite these limitations, both studies confirmed the Osteoglossomorpha as one of the primary basal teleostean lineages.

Most subsequent molecular studies identified three main monophyletic teleostean groups, as do morphological studies: Elopomorpha, Osteoglossomorpha, and Clupeocephala (comprising Clupeomorpha, Ostariophysi and Euteleostei) (Fig. 15a). However, molecular data provide unclear results regarding to the phylogenetic position of Osteoglossomorpha relative to the two other lineages (Elopomorpha and Clupeocephala) because of the unresolved position of the root (Fig. 15a). There is a tendency in recent molecular studies using large taxonomic samplings and sets of several genes to identify Elopomorpha as the sister group of the rest of Teleostei with the consequence that Osteoglossomorpha and Clupeocephala form a monophyletic group (Near et al., 2012; Betancur-R et al., 2013; Chen et al., 2014). This phylogenetic arrangement is at best moderately supported by statistics (such as Bootstrap values) and often alternative arrangements cannot be rejected statistically. Other molecular studies present different hypotheses such as the sister relationship between Osteoglossomorpha and Elopomorpha (Le et al., 1993) or the sister relationship between Elopomorpha and Clupeocephala (Inoue et al., 2003; Johnson et al., 2012) (Fig. 15a) or a polytomy among the three groups (Li et al., 2008).

Four recent genomic studies, each based on several thousand molecular characters (sampled across the whole genome) but few taxa found conflicting results: Chen et al. (2014) and Bian et al. (2016) supported the hypothesis of a sister group relationship between Elopomorpha and Osteoglossomorpha, whereas Austin et al. (2015) recovered Osteoglossomorpha as the sister group of all other Teleostei and Faircloth et al. (2013) recovered Elopomorpha in this position (Fig. 15a). Shen et al. (2017) examined the distribution of the phylogenetic signal in the dataset of Chen et al. (2014) and found that only a small subset of genes provides support for Elopomorpha + Osteoglossomorpha over Elopomorpha + Clupeocephala; Shen et al. (2017) did not evaluate the third hypothesis (i.e., Elopomorpha is the sister group of the rest of Teleostei). Therefore, molecular data, so far, has not provided unambiguous phylogenetic signal to resolve the question of the phylogenetic position of Osteoglossomorpha within Teleostei. We note that the two most recent studies that examined this question (i.e., Hughes et al., 2018; Vialle et al., 2018) also provided contrasting results.

Molecular phylogeny of Osteoglossomorpha. The higher-level (i.e., inter-familial level) relationships of Osteoglossomorpha have been addressed in a few molecular studies. Among these studies, those based on a single gene (such as cytochrome $b$ or $18 \mathrm{~S}$ rDNA) have been shown to produce unreliable phylogenetic results (relative to the phylogeny of Osteoglossomorpha) because of weak resolution, weak support, and variable or unexpected tree topologies (e.g., Kumazawa, Nishida, 2000; Santini et al., 2009; Mu et al., 2012, 2013). This is likely the consequence of the limited and low quality (i.e., high-level of homoplasy content) of phylogenetic signal when using such single gene. Contrary to the single-gene approach, the multi-gene phylogenetic studies tend to produce highly similar (often identical) topological hypotheses (see below).

At higher-levels, Lavoué, Sullivan (2004) was the first molecular phylogenetic study of Osteoglossomorpha in which Hiodon (Hiodontiformes) and at least one representative of each osteoglossiform family were examined together. Their most-parsimonious phylogenetic tree of Osteoglossomorpha based on the analysis of five genes (Fig. 15b) shows Hiodontiformes (Hiodon alosoides) to be the sister group of Osteoglossiformes. Within the Osteoglossiformes, Pantodon buchholzi is the sister group of the rest of the taxa and Osteoglossidae (minus P. buchholzi) is the sister group of Notopteroidei (= Notopteridae (Gymnarchidae + Mormyridae)). Within Osteoglossidae, two lineages were identified, one including Arapaima gigas and Heterotis niloticus and another comprising Scleropages sp. and Osteoglossum bicirrhosum. The main difference between this molecular tree and previous morphological hypotheses is the position of Pantodon. While the overall topology of this tree (Fig. 15b) is well supported, the branch supporting Pantodon is significantly longer than the other branches, which could indicate a difficulty for reliably inferring the placement of Pantodon (i.e., potentially a case of long branch attraction; Bergsten, 2005). Several subsequent studies that addressed the phylogenetic position of Pantodon within Osteoglossomorpha using different characters and taxonomic sampling found si- 

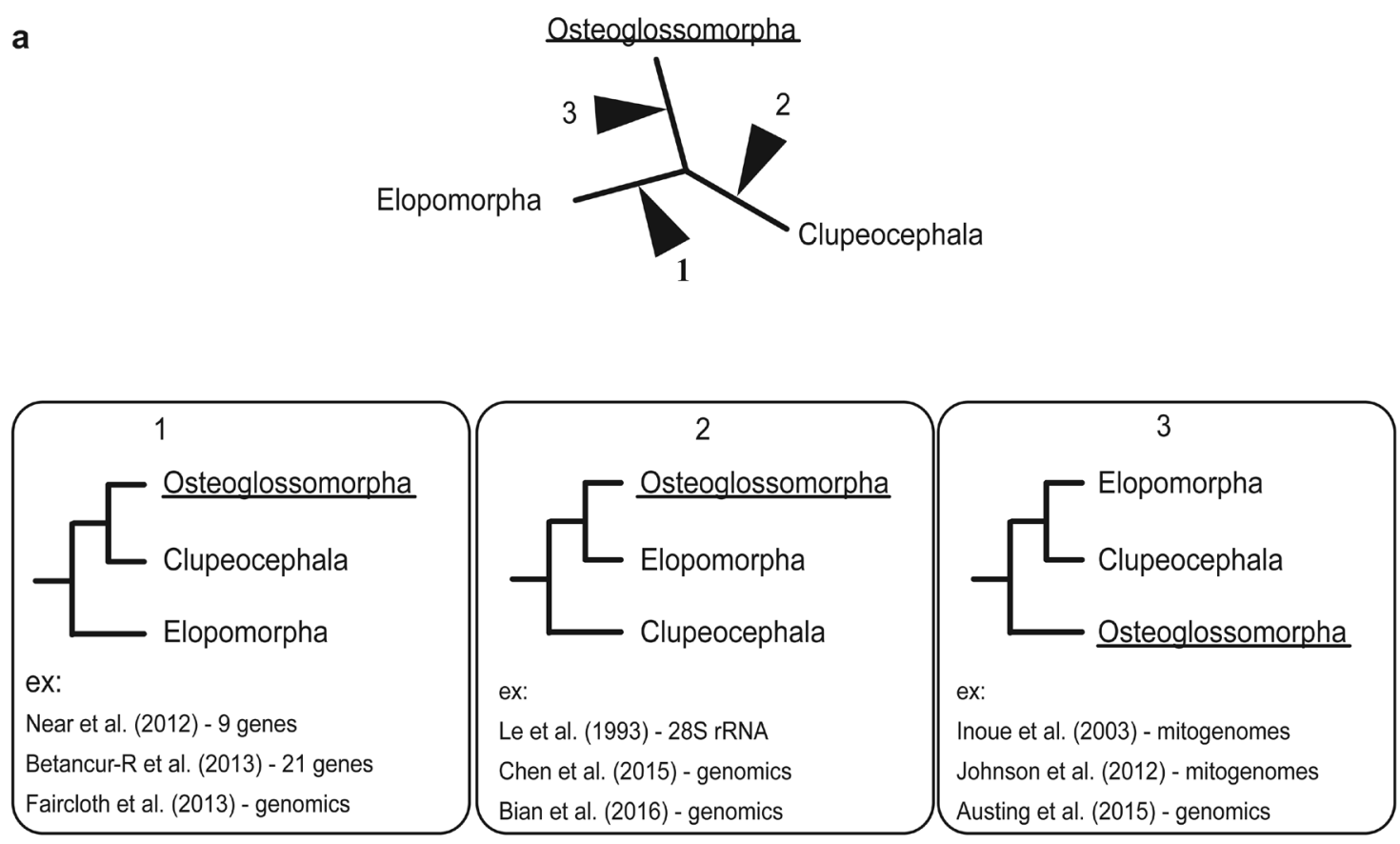

b

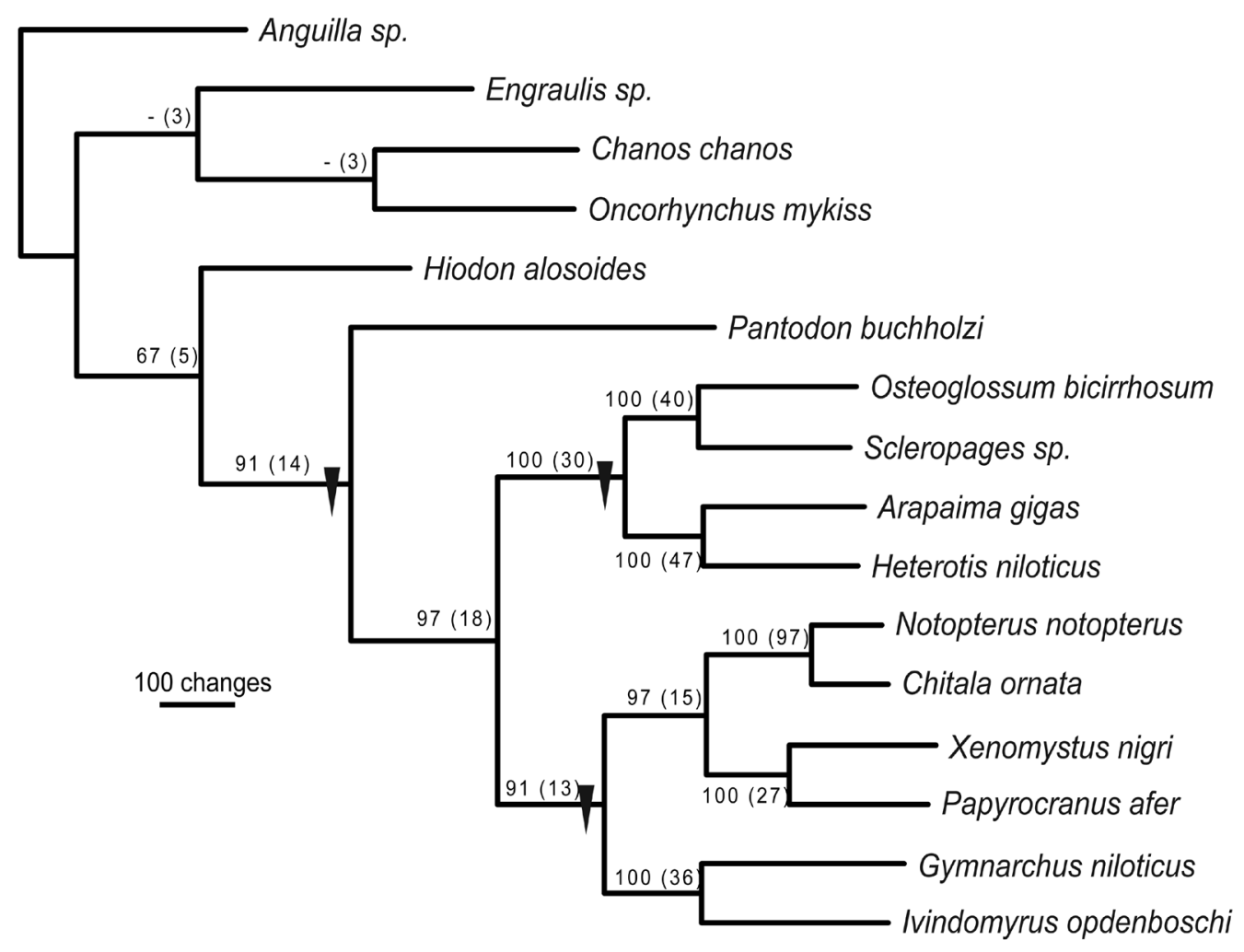

Fig. 15. Molecular systematics of Osteoglossomorpha. a. The phylogenetic positions of Osteoglossomorpha relative to Elopomorpha and Clupeocephala as inferred from molecules. Each arrow-head indicates a root position on the same unrooted topology providing three different hypotheses (1 to 3). For each rooted topology, three references are given. b. A molecular phylogenetic tree of Osteoglossomorpha (modified from Lavoué, Sullivan, 2004). This is the single most-parsimonious tree recovered from a dataset of five molecular markers (12S and 16S rRNA, cytochrome b, RAG2, and MLL). Bootstrap proportions ( $>50 \%)$ and Bremer support indices (in parentheses) are indicated at nodes. Synapomorphic molecular insertions from $12 \mathrm{~S}$ rRNA are shown by inverted triangles. 
milar results as Lavoué, Sullivan (2004). In particular, Inoue et al. (2009), Lavoué et al. (2011) and Lavoué et al. (2012) examined the phylogeny of Osteoglossomorpha using complete mitogenomic sequences but different taxonomic samplings; all inferred the same tree topology.

Near et al. (2012) reconstructed the phylogeny of more than 230 ray-finned fish species (including nine osteoglossomorph species but, noticeably, not Pantodon) using a nine-nuclear-gene dataset also found the same topology as previous analyses. Betancur-R et al. (2013) examined a larger dataset (more than 1400 teleost species and 20 nuclear genes along with one mitochondrial gene, 16S sRNA). Both studies found similar results to Lavoué, Sullivan (2004) except for the position of Pantodon in Betancur-R et al. (2013), which was recovered as the sister group to the rest of osteoglossids examined (i.e., Arapaima gigas, Heterotis niloticus and Osteoglossum bicirrhosum). However, the dataset of Osteoglossomorpha of Betancur-R et al. (2013) contains more than $50 \%$ missing data and a recent re-analysis of this dataset placed Pantodon as the sister group of the rest of Osteoglossiformes (Betancur-R et al., 2017). Lavoué (2016) combined the morphological dataset of Hilton (2003), as modified by Wilson, Murray (2008), with the mitogenomic dataset of Lavoué et al. (2012) and the nuclear gene datasets of Near et al. (2012) and Betancur-R et al. (2013) to reconstruct the phylogeny of Osteoglossomorpha. Analytical results provided a tree topology identical to that of Lavoué, Sullivan (2004) in which Pantodon is the sister group of the rest of Osteoglossiformes. Bian et al. (2016) is the first genomic study in which the phylogenetic position of Pantodon, relative to Notopteroidei (only Papyrocranus afer sampled) and Osteoglossidae (only Scleropages formosus sampled) could be investigated. The authors found Pantodon sister group of $S$. formosus, keeping open the question of the position of Pantodon in molecular systematics. Finally, in the most recent genomic study to date, Hughes et al. (2018) found Pantodon sister group of the rest of Osteoglossiformes (Hiodontiformes was not sampled).

Molecular systematics at or below the family level. At lower-level (i.e., intra-familial levels), molecular phylogenetic analyses of several osteoglossiform families have been conducted to produce frameworks to explore the evolution of some remarkable traits in these fishes. For example, based on topologies generated by novel molecular data, Sullivan et al. (2000) studied the evolution of the cell-anatomy of the electric organs of African weakly electric fishes (Mormyridae and Gymnarchidae), based on a new phylogenetic hypothesis, Carlson et al. (2011) studied the evolution of their brain, and Lavoue et al. (2012) studied the origins and timing of the electric sense in Osteoglossomorpha and Teleostei.

Molecular-based phylogenies have also served as the basis for biogeographical analyses, radiation, and conservation. Inoue et al. (2009) examined the phylogeny of Notopteridae to test biogeographical hypotheses relative to their distribution. Lavoué (2015) specifically tested some biogeographical hypotheses relative to the distribution of the trans-Wallace's Line distributed genus Scleropages in reconstructing the phylogeny of this genus within the Osteoglossidae. Feulner et al. (2007), Sullivan et al. (2004) and Arnegard et al. (2010) examined the speciation process within genera of African weakly electric fishes. Finally, the genetic population structure of osteoglossomorph species listed in the "IUCN Red List of Threatened Species" was recently reported for conservation purpose, including Arapaima gigas (Hrbek et al., 2005; Araripe et al., 2013) and Scleropages formosus (Yue et al., 2000, 2003, 2006; Mohd-Shamsudin et al., 2011).

Biogeography of Osteoglossomorpha. Osteoglossomorpha has attracted much attention from biogeographers studying trans-oceanic distributions of non-marine taxa (Cracraft, 1974; Darlington, 1957; Nelson, 1969) because they are charismatic, easy to identify, their systematics was studied in early cladistic frameworks, and they are distributed on all continents except Antarctica, thereby exhibiting several inter-continental allopatric taxa pairs (i.e., Neotropical Arapaima/Afrotropical Heterotis; Oriental Scleropages/ Australian Scleropages; Oriental Notopterinae/Afrotropical Xenomystinae; Nearctic Hiodontiformes/Gondwanan Osteoglossiformes, etc.). Further, they have a rich fossil record (including several marine forms) dating back to the Late Jurassic or Early Cretaceous (†Paralycoptera, Tse et al., 2015) and, therefore, they are considered to be one of the oldest living freshwater teleost lineages. The distribution of Osteoglossomorpha was either discussed as a whole (Nelson, 1969; Taverne, 1979; Li, 1997; Wilson, Murray, 2008) or in part: e.g., Arapaima/Heterotis (Lundberg, Chernoff, 1992), Notopteridae (Inoue et al., 2009), Osteoglossidae (Bonde, 1996; Forey, Hilton, 2010), Oriental Scleropages/Australian Scleropages (Darlington, 1957; de Beaufort, 1964; Lavoué, 2015). Sometimes, the distribution of Osteoglossomorpha was part of a more general discussion on the biogeographical relationships of continental regions, such as Neotropics versus Afrotropics (Cracraft, 1974; Lundberg, 1993), Neotropics versus Australia (Cracraft, 1974) or the Gondwanan breakup (Cavin, 2008; Lavoué, 2016; Nelson, Ladiges, 2001; Patterson, 1975).

The work of Nelson (1969) marked a radical methodological change in the study on the biogeography of Osteoglossomorpha because this author was the first to use a synapomorphy-based phylogeny to reconstruct the ancestral regions at nodes within the context of plate tectonics (Fig. 16). Nelson, however, limited his analysis to extant taxa with little consideration for the information that osteoglossomorph fossils can bring (such as minimum age or past range extension or past ecological associations). Patterson (1975) based his analysis on a modified version of Nelson's (1969) tree, in which mormyrids are transferred as the sister group of notopterids (Greenwood, 1971; Fig. 16). Importantly, he added two fossils in the tree: $\dagger$ Lycoptera as the sister group of Hio- 
dontidae and $\uparrow$ Brychaetus as the sister of Osteoglossidae plus Pantodontidae. Doing this, Patterson (1975) provided a strict minimum age for the base of the Osteoglossomorpha tree corresponding to the age of the oldest fossil, $\dagger$ Lycoptera. He also discussed the evidence of possible marine dispersal in the Osteoglossidae-Pantodontidae lineage because $\uparrow$ Brychaetus is a marine taxon. Taverne (1979) published a fully dated phylogeny of Osteoglossomorpha in including many fossils. Taverne (1979) used this tree to discuss the biogeography of these fishes but without explicitly reconstructing ancestral areas at nodes. Li (1997) briefly reviewed the knowledge on the biogeography of Osteoglossomorpha at that time and he provided his own hypothesis based on his phylogenetic results (Li, Wilson, 1996a). Wilson, Murray (2008) reviewed more extensively the fossil record and biogeography of Osteoglossomorpha and Forey, Hilton (2010) provided the most complete critical account, to date, on the significance of the many fossils that have been related to Osteoglossidae and their value to study the biogeography of Osteoglossidae.

Below, we review recent hypotheses of the historical biogeography of Osteoglossomorpha, specifically addressing splits between Arapaima and Heterotis, Osteoglossum and Scleropages, and within Notopteridae. We emphasize the importance of timing (to test vicariance hypothesis) and habitat constrains (relative to temperature and salinity) in the biogeography of trans-oceanic pair taxa that are regularly discussed.

Biogeography of Arapaima and Heterotis. Neotropical freshwater fishes has attracted attention of biogeographers because, in particular, of the similarity of this fauna and that of the Afrotropics, which was noticed more than 100 years ago (Eigenmann, 1912; Regan, 1922), well before the theory of continental drift of Wegener (1915) radically transformed the field of biogeography (Gosline, 1975; Hallam, 1967; Patterson, 1975). In this context, the trans-Atlantic distribution of (Arapaima, Heterotis) has been discussed (Cavin et al., 2008; Cracraft, 1974; Lundberg, 1993; Lundberg, Chernoff, 1992); yet there is no consensus to explain their distribution because of the uncertain phylogenetic position of some "stem or crown arapaimin" fossils (Forey, Hilton, 2010; Lundberg, Chernoff, 1992) and the age of the divergence between Arapaima and Heterotis. Three hypotheses are commonly proposed to explain the Neotropical-Afrotropical distribution of Arapaima and Heterotis: 1) the previcariance hypothesis, which postulates that the divergence between Arapaima and Heterotis predated the fragmentation of South America and Africa (Lundberg, Chernoff, 1992; Fig. 16); 2) the tectonicmediated vicariance hypothesis, which postulates that the divergence Arapaima and Heterotis was the consequence of the separation of Africa and South America (Nelson, 1969; Fig. 16); and the post-fragmentation dispersal (marine or geodispersal) hypothesis, which postulates that the divergence between Arapaima and Heterotis postdated the final fragmentation between Africa and South America (Bonde, 1996, 2008). In theory and under some circumstances (such as rates of regional extinction), each of these three hypotheses can generate a sister group relationship between Arapaima and Heterotis. However, timing is critical as it provides a strong test of the vicariance hypothesis: the vicariance hypothesis is not rejected if the time divergence between Arapai$m a$ and Heterotis overlapped the time of the final separation of Africa and South America (about $105 \mathrm{Ma}$ ).

Nelson (1969; Fig. 16) and Nelson, Ladiges (2001) hypothesized that the ancestral region of the clade (Arapaima, Heterotis) was "Africa plus South America"; these authors did not include any timescale although Nelson, Ladiges (2001) mentioned the molecular work of Kumazawa, Nishida (2000) in which a timescale is provided. Lundberg, Chernoff (1992) hypothesized that the divergence between Arapaima and Heterotis predated the fragmentation of South America and Africa because they considered the Neotropical fossil $\uparrow$ Laeliichthys (Aptian, about $110 \mathrm{Ma}$ ) more closely related to Heterotis (plus $\dagger$ Paradercetis) than to Arapaima (Taverne, 1979; Fig. 16). Therefore, the divergence between Arapaima and the Heterotis lineage must have predated the separation of Africa and South America. However, the phylogenetic placement of $\uparrow$ Laeliichthys (and $\dagger$ Paradercetis) was criticized by several researchers (see Bonde, 1996; Forey, Hilton, 2010). In particular, Bonde (1996) produced a dated phylogenetic tree in which the divergence between Arapaima and Heterotis is Eocene, therefore de facto rejecting the vicariance hypothesis and favoring a post-fragmentation (likely marine; see indirect evidence in Bonde, 2008) dispersal hypothesis. Recent molecular works favored the post-fragmentation divergence in estimating the time of divergence between Heterotis and Arapaima, which is strictly younger (105 Ma) than the breakup of South America and Africa (Lavoué, 2016),

Beside $\dagger$ Laeliichthys and $\dagger$ Paradercetis, the paleontological evidence to date the divergence of Arapaima and Heterotis is scarce. Otero, Gayet (2001) assigned very fragmentary fossils from the Oligocene or Miocene (about 31-23 Ma) to Heterotis that make them the earliest record of this lineage. Some Paleocene remains of Arapaima-like specimens represent the earliest record of the lineage Arapaima in South America (Forey, Hilton, 2010; Gayet, Meunier, 1983; Lundberg, Chernoff, 1992); fossils of Arapaima and Heterotis have never been found outside their current continental regions. A strict interpretation of the fossil record, therefore provide a strict minimum age of about $56 \mathrm{Ma}$ for the divergence between Heterotis and Arapaima. The Eocene $†$ Sinoglossus lushanensis ( $\mathrm{Su}, 1986)$ is closely related to this clade, either as its sister group (Forey, Hilton, 2010; Li, Wilson, 1996b) or in an unresolved position relative to Heterotis and Arapaima (Li, Wilson, 1996a; Lavoué, 2016; Wilson, Murray, 2008). The uncertainty in the phylogenetic position of $\uparrow$ Sinoglossus from China adds difficulties to resolve the biogeography of Arapaima and Heterotis but it does not modify the current evidence that the divergence postdated the separation between Africa and South America. Other Paleocene and Eocene fossils may represent stem representatives of the clade (Arapaima, Heterotis) such as $\dagger$ Joffrichthys (Nearctics, 

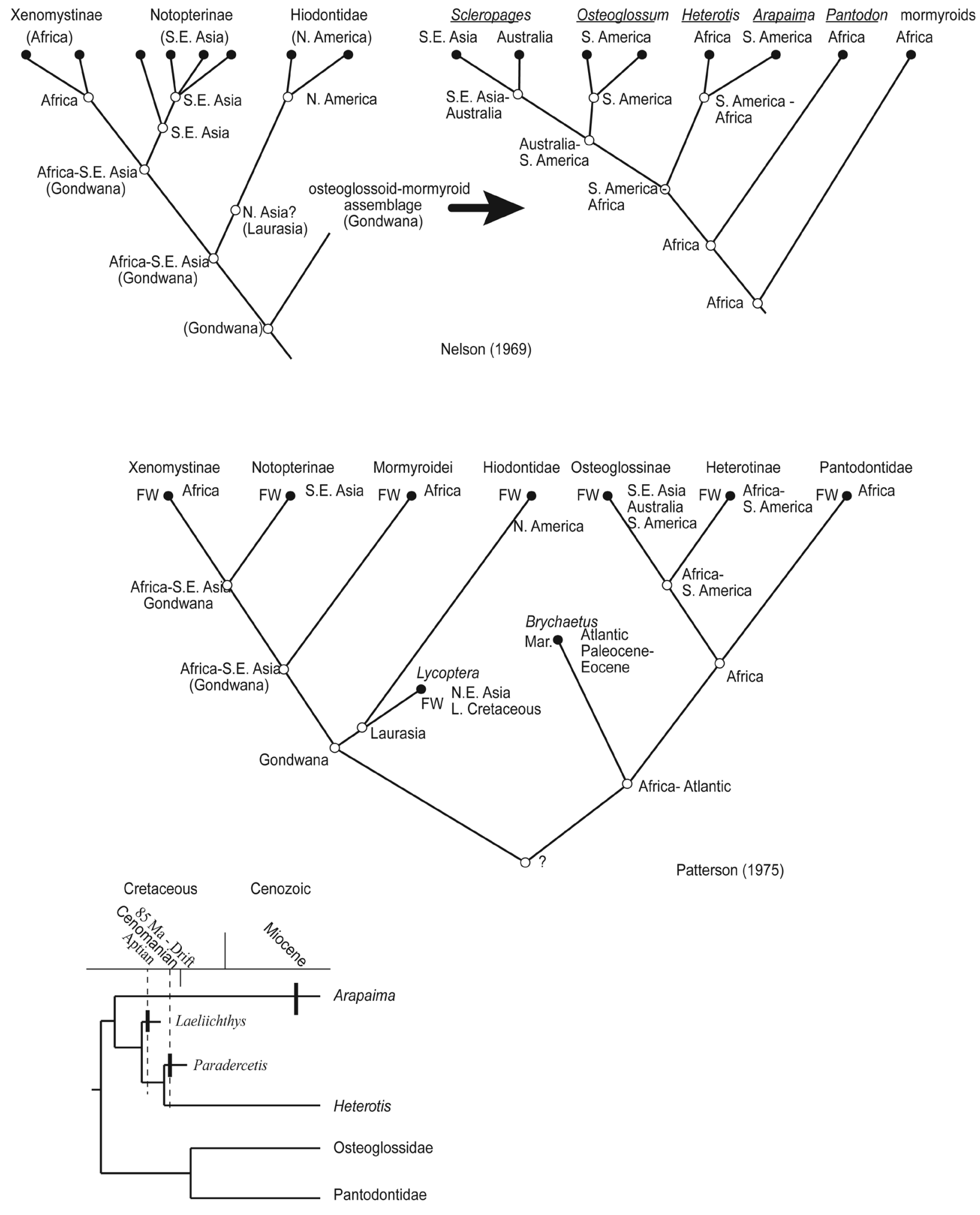

Lundberg and Chernoff (1992)

Fig. 16. Phylogeny-based biogeographic hypotheses. Nelson (1969), Patterson (1975), Lundberg, Chernoff (1992).

Paleocene, freshwater; Li, Wilson, 1996b, though see Murray et al., 2018) and $\dagger$ Trissopterus (West Palearctic, Eocene, marine; Bonde, 2008; Taverne, 1998).
Evidence related to timing is growing to support transAtlantic dispersal during the Cenozoic not just for Arapaima and Heterotis but also for several trans-Atlantic groups of 
fishes (including Cichlidae, Polycentridae, and Siluroidei), well after the separation of Africa and South America (Lundberg et al., 2007; Near et al., 2012; Friedman et al., 2013; Lavoué, 2016; Matschiner et al., 2017). However, the mechanism(s) of these dispersal events is still not known. Often, direct marine dispersals were proposed as ad hoc hypotheses to explain these post-drifting faunistic exchanges (Briggs, 2003; Matschiner et al., 2017). However, in the case of Arapaima and Heterotis, there is no convincing evidence that the most recent common ancestors were marine adapted (Lavoué, 2016; Sparks, Smith, 2005; but see Bonde, 2008; Taverne, 1998). Moreover, although in theory it is possible, the marine dispersal hypothesis explaining the distribution of Arapaima and Heterotis seems highly unlikely because it necessitates the combination of four rare evolutionary events (Fig. 17): one "freshwater-to-marine" transition, one long-distance marine dispersal, one "marine-to-freshwater" transition and, finally, the selective extinction of marine organisms on each side of the marine environment. Recent habitat preference reconstructions using phylogenetic trees show that environmental transitions are rare events in Teleostei (Bloom, Lovejoy, 2012; Davis et al., 2012; Lavoué et al., 2012; Conway et al., 2017).

While direct trans-oceanic dispersals seem unlikely, other dispersal processes must be hypothesized to account for such trans-Atlantic faunistic exchanges during the Cenozoic. The geodispersal hypothesis between Africa and South America (or vice versa) through the Holarctic route "North America (= Nearctics) -Greenland region-West Europe (West Palearctics)" represents an alternative to the direct marine dispersal to explain the inter-continental exchanges of freshwater fishes from the end of the Cretaceous to the Eocene (Fig. 17). At first glance, geodispersal through Northern hemisphere may also seem unlikely for tropical freshwater fish because 1) the current climatic conditions in the northern hemisphere (above 30 degree latitude) are, at the best, temperate during summer and often cold during winter; this is unsuitable for warm-adapted organisms such as tropical fishes and 2) three trans-continental land bridges, supporting continuous freshwater systems, must have existed synchronously or repetitively between South-America and North America, North America and Europe and Europe and Africa during the Late Cretaceous-early Cenozoic interval.

Biogeography of Osteoglossum and Scleropages. The distribution of the lineage including Osteoglossum and Scleropages is unique among recent fishes in spanning the following three continental regions: Neotropics (two species of Osteoglossum), Australia (two species of Scleropages) and Orient (two species of Scleropages). Because of that, the region where the most recent common ancestor of this lineage lived is still mostly unknown. The fossil record documents the presence of Scleropages in Orient and in Australia in the early Eocene and Oligocene, respectively (Hills, 1934, 1943; Zhang, Wilson, 2017). Very incomplete fossils from
India (Maastrichtian), Europe (Palaeocene), Sumatra (Eocene) and Africa (Palaeocene) have also been assigned to Scleropages (Kumar et al., 2005; Taverne et al., 2007; Nolf et al., 2008; Sanders, 1934; Taverne, 2009c). These fossils are all freshwater forms. Bonde (2008) described several marine fossils as stem to the clade Scleropages + Osteoglossum, but none as crown. There is no fossil of Osteoglossum. The extant species of Scleropages form a putatively monophyletic group hat is the sister group of Osteoglossum.

Some studies postulated that "South America + Australia + East Antarctica" was the region where lived the ancestor of the clade Osteoglossum + Scleropages during the Eocene/ Oligocene followed by one vicariant event between South America and "Australia plus East Antarctica" (and extinction in East Antarctica), then followed by a marine dispersal event between Australia and Orient (which explains the presence of extant Scleropages in Orient) (Cracraft, 1974; Nelson, 1969). The recent discovery of the Eocene $\uparrow S$. sinensis in the Orient refutes in part this scenario because it forced the divergence between Scleropages and Osteoglossum to predate the final separation of South America and "East Antarctica-Australia". Lavoué (2016) dated the divergence between Scleropages and Osteoglossum broadly between 80-45 Ma but without considering $\dagger S$. sinensis, which was described later (Zhang, Wilson, 2017).

Given the current evidence, the most likely hypothesis to explain the trans-marine distribution of Scleropages is a marine dispersal between Australia and Orient across Wallace's Line; the ancestral region where the most recent common ancestors of Osteoglossum and Scleropages lived is unresolved.

Biogeography of Notopteridae. It is only recently that the biogeography of Notopteridae has been investigated. Phylogenetic and paleontological evidence strongly support the hypothesis that the monophyletic Asian Notopterinae originated from Afrotropics. The oldest notopteroid fossil known is $\dagger$ Palaeonotopterus greenwoodi from the Cenomanian of Morocco (Forey, 1997). This fossil provides a strict minimum age of $94 \mathrm{Ma}$ for the presence of the Notopteroidei in Africa. Notopterid otoliths ("genus Notopteridarum" Nolf et al., 2008) from the Deccan Intertrappean Beds (India), dated to the Late Cretaceous (66 Ma), mark the earliest presence of Notopteridae in Asia. However, these otoliths do not share the modification present in recent species, leading Nolf et al. (2008) to suggest that they should belong to some stem notopterid species. Another Asian fossil Notopteridae was described from the Eocene of Sumatra (56.0-33.9 Ma) (Sanders, 1934). This fossil is very similar to the living Notopterus and it provides a strict minimum age for the presence of the crown group Notopterinae in Asia.

Two biogeographical hypotheses have been proposed to explain the distribution of the Asian Notopteridae: 1) the tectonic mediated vicariance hypothesis caused by the separation of Africa and India (the "Indian ferry" hypothesis) (Inoue et al., 2009), and 2) the Miocene geodispersal 


\section{"Africa to South-America" (or vice versa) post-continental drifting alternative hypotheses}
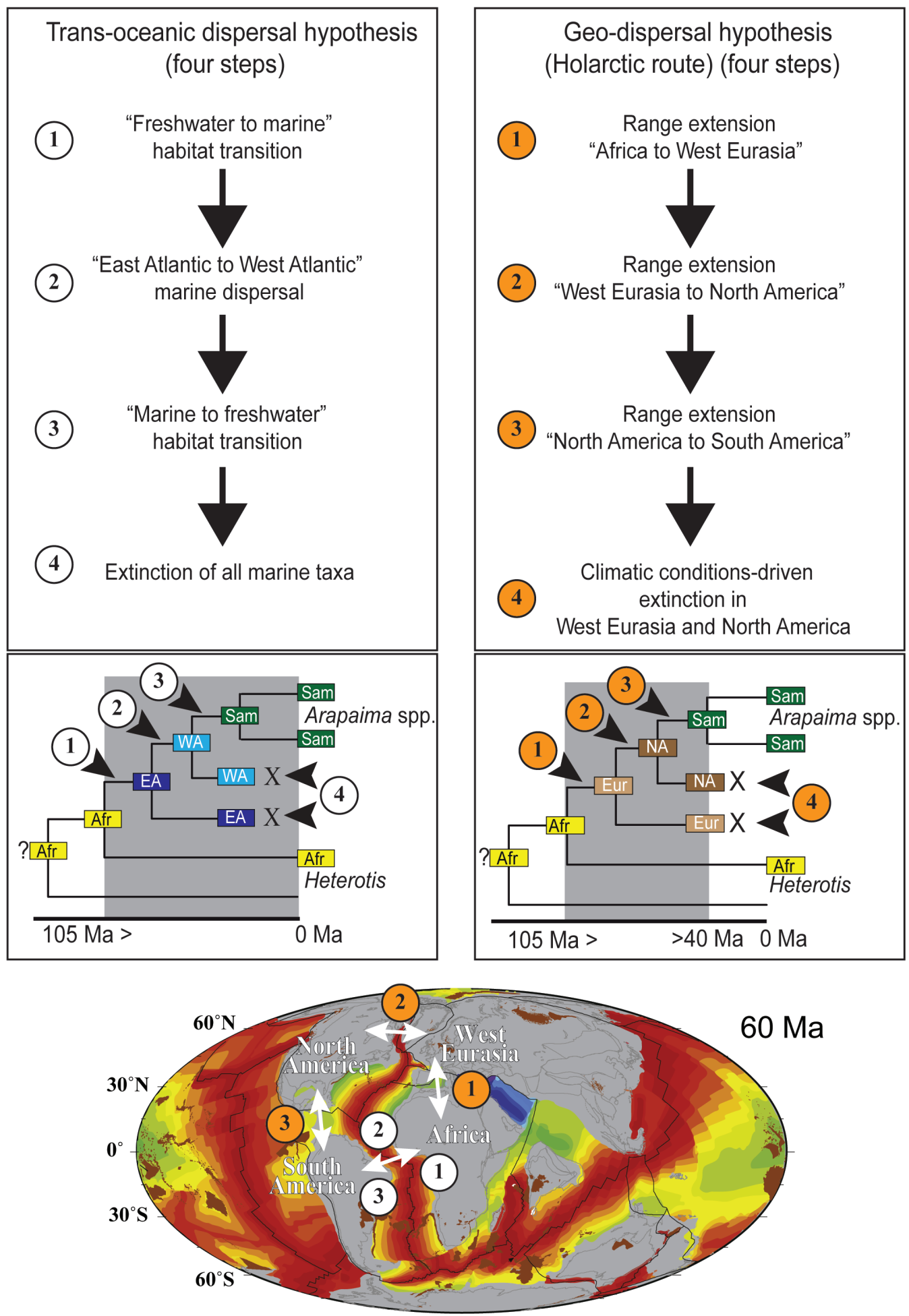

Fig. 17. Evolutionary events supporting the marine and geodispersal dispersal hypotheses to explain the distributions of Arapaima and Heterotis. Each dispersal hypothesis requires four main evolutionary events (that are mapped on time calibrated phylogenetic trees and a 60 Ma paleomap reconstruction). Paleomap modified from Seton et al. (2012). Timescale in million years ago (Ma). For each hypothesis, possible ancestral areas at nodes shown on phylogenies (Abbreviations: Afr, Africa (Afrotropics); Sam, South America (Neotropics); NA, North America (Nearctics); Eur, West Eurasia (West Palearctics); EA, East Atlantic; WA, West Atlantic. "X" means extinction). Grey rectangles indicated time limit for each hypothesis. 
hypothesis, which is linked to the collision between Africa and Eurasia (Bănărescu, 1991). Inoue et al. (2009) estimated the divergence between Notopterinae and Xenomystinae broadly between $160 \mathrm{Ma}$ and $110 \mathrm{Ma}$. These authors did not reject the vicariance hypothesis but the age of the Teleostei was overestimated to $300 \mathrm{Ma}$. Within the hypothesis that Teleostei is about 200 Ma, Lavoue (2016) re-estimated the time divergence between Notopterinae and Xenomystinae to 83.2 Ma (95\% CI: $105-60 \mathrm{Ma}$ ) with the conclusion that the tectonic mediated vicariance hypothesis should be rejected. In the same study, the age of the crown group Xenomystinae was roughly estimated to $50 \mathrm{Ma}$. In agreement with this molecular dating (Lavoué, 2016), the presence of the Notopterus-like fossil in Sumatra (Sanders, 1934) rejects the second hypothesis.

Therefore, a third dispersal hypothesis (marine?) should be considered in which the dispersal event would have occurred between a maximum of $100 \mathrm{Ma}$ and a minimum of $50 \mathrm{Ma}$ (maybe $66 \mathrm{Ma}$ if the fossil otoliths found in India are related to Notopterinae). Lavoué, Sullivan (2004) noted that Asian notopterids loose the electroreception sense, and they speculated this could be the result of a marine dispersal event between Africa and Asia. Future investigations should consider the following two points: 1) this spatio-temporal pattern is similar to the distribution of other groups of freshwater fish (e.g., cichlids, cyprinodontiforms, and possibly $\uparrow$ Sinoglossus and Heterotis); 2) The Indian subcontinent during the Late Cretaceous-Early Cenozoic does not look biogeographically isolated from Africa (reviewed in Verma et al., 2016 and Vérard et al., 2017, including freshwater fishes, Nolf et al., 2008), as the current paleogeological reconstructions would suggest (Ali, Aitchison, 2008; Chatterjee et al., 2013; Gaina et al., 2015). Recent studies, such as Torsvik et al. (2013), improve the paleogeological reconstruction of the Indian Ocean region during the Cretaceous-Early Cenozoic and show that this region was more complex than previously thought. Further study is needed to better understand the biogeography of this region.

\section{Future research needs}

Reassessment of the morphology and systematics of fossil and living osteoglossomorphs. The morphology of osteoglossomorph fishes has been intensively studied for a long time. Many of the preeminent ichthyologists of the $19^{\text {th }}$ century (e.g., Cuvier, Agassiz, Cope, and others) offered much of the early taxonomic descriptions and a lot of anatomical characters and broad comparisons, many of which persist now. These studies culminated in Ridewood's $(1904,1905)$ papers on the skull of osteoglossomorphs and other basal teleosteans fishes (his underlying approach foreshadowing cladistic phylogenetic analysis; Hilton, Forey, $2005)$. Throughout much of the $20^{\text {th }}$ century, the morphology of individual taxa were explored in varying levels of detail, but it was not until Taverne's monographic treatments of osteological data that Osteoglossomorpha was treated in a comprehensive, systematic manner. Since these studies there have been many studies focused on individual aspects of osteoglossomorph anatomy and descriptions of many new fossil taxa. Given the abundant newly described taxa, new data matricies, and new definitions and discussions of morphological characters related to Osteoglossomorpha that have been published recently (e.g., Hilton, 2003; Murray, Wilson, 2005; Zhang, 2006; Leal, Brito, 2007; Wilson, Murray, 2008; Bonde, 2008; Xu, Chang, 2009; Taverne, 2009a,b,c; Taverne et al., 2009; Hilton, Britz, 2010; Forey, Hilton, 2010; Murray et al., 2010, 2016, 2018), the time seems good for a complete reassessment of characters and new study of relationships among all taxa. Further, many of the recently described fossil taxa need to be reexamined and incorporated into an expanded comparative data set. Given the technological advances that have been developed for the study of anatomy, including the comparative study of soft tissues and ontogeny (Hilton et al., 2015), which are virtually unstudied for osteoglossomorphs, there remain, even in this well studied group, many unknown aspects of their comparative anatomy that will undoubtedly prove useful for understanding their phylogenetic relationships.

Morphology of Mormyridae and intrafamilial relationships. In an extensive series of papers, Taverne (1967, 1968a, b, 1969, 1970, 1971, 1972) established a taxonomically robust source of osteological data for mormyroid fishes. Since that time, significant variation within the family continues to be documented (e.g., in the caudal skeleton and its development; Hilton, Britz, 2010). Within Mormyridae, the hypotheses of relationships among genera that were proposed by Taverne (1972) have been largely untested by morphological data (e.g., through collection of new data, by different approaches for character conceptualization, etc.), and the time seems ripe to revisit the relationships among mormyrid genera based on new morphological observations. Further, several genera have been recovered as non-monophyletic by genetic analyses (e.g., Sullivan et al., 2000), and these now must be reconsidered and redefined.

Embryology and early ontogeny of Hiodon As putatively the basal most extant osteoglossomorph genus, Hiodon is considered to be of great systematic importance, and is often used as a representative osteoglossomorph in broad phylogenetic analyses (e.g., Arratia, 2001; Hurley et al., 2007). Hiodontids have semi-buoyant eggs, and this is among the earliest occurrence of such an egg type found in Teleostei. Among the smallest larval specimens of $H$. tergisus described in the literature is a $7.1 \mathrm{~mm}$ specimen (Snyder, Douglas, 1978). Battle, Sprules (1960) described the embryology and larval development of $H$. alosoides, based on specimens prehatching stages, as well as $7.27 \mathrm{~mm}$ larvae. Both studies focus on external features and larval identification (see also Wallus, 1986). Two morphological 
studies have focused on the osteology of this taxon (Taverne, 1977; Hilton, 2002), yet there is still a poor understanding of the early developmental stages of Hiodon. For example, the smallest stages available to Hilton (2002) for his osteological study was $21 \mathrm{~mm} \mathrm{SL}$, and the smallest specimens used by Schultze, Arratia (1988) in their study of the development of its caudal skeleton was $22 \mathrm{~mm} \mathrm{SL}$. By these stages, many of the skeletal elements are already present, particularly in the cranial skeleton, and therefore there is no data, for instance, on the relative timing of skull bones. Ontogenetic data can be important for homology assessment, for example, and as character data in systematic studies (Leis et al., 1997; Hilton et al., 2015).

Species limits among classically monotypic taxa. With the suggestion that there is more than a single extant species of Arapaima (Stewart 2013a,b), the question arises whether there remains cryptic species within other traditionally held monotypic genera. Certainly, population-level structure for wide-ranging, monotypic osteoglossomorph taxa can be informative (e.g., for biodiversity and conservation purposes), whether or not variation (morphological or genetic) is determined to be at the level of distinct species. Other monotypic taxa for that are good candidates for reconsideration are Scleropages formosus, Heterotis niloticus, Xenomystus nigri, Notopterus notopterus, and Gymnarchus niloticus (e.g., Roberts, 1992). Pantodon buchholzi would appear also to be a good candidate for testing its monotypic status, being distributed with two widely disjunct populations in the $\mathrm{Ni}$ ger and Congo basins. Lavoué et al. (2011) found very little morphometric divergence between these two populations, despite finding genetic divergence that was suggestive of more than 50 million years of separation. New morphological data, including internal anatomy, should now be assessed for Pantodon.

Phylogenetic affinities of Pantodon. Pantodon has long been recognized to be a problematic taxon in the context of understanding the phylogeny of Osteoglossomorpha. Although generally recovered as close, if not within Osteoglossidae, the relationships of Pantodon to other osteoglossomorphs is problematic (e.g., Nelson 1968, 1969 discussed the conflicting nature of gill arches, infraorbital bones, and other aspects of its anatomy, which suggested either a sister group relationship to either Osteoglossidae or Osteoglossinae). This phylogenetic difficulty was further discussed by Hilton (2003) in an analysis that removed all fossil taxa included in his matrix. The resulting strict consensus tree had a topology that was largely consistent with that of the full analysis, with the exception that Pantodon was recovered in a polytomy with Notopteridae and Osteoglossidae (i.e., in the fundamental trees it was interpreted as either the sister group of Notopteridae or Osteoglossidae, or nested within Osteoglossidae). This was offered as an example of the use of fossils as arbiters between competing hypotheses of relationships. The characters supporting each of these alternati- ve hypotheses were not fully explored in this analysis, and the character conflict within Osteoglossomorpha as related to the affinities of Pantodon need to be more fully understood. Based on molecular data, Lavoué, Sullivan (2004; also Lavoué, 2016) found Pantodon to be the sister group of the rest of Osteoglossiformes (but see Betancur-R et al., 2013; Bian et al., 2016, and discussion above). At this point, new morphological and molecular analyses are needed to further address the phylogenetic position of Pantodon within Osteoglossomorpha.

Systematic biology, taxonomy, and monophyly of Scleropages. Traditionally, three species have been recognized in the genus Scleropages: S. jardinii and S. leichardti from tropical Australia, and the widespread species $S$. formosus, found from the Mekong basin, Thailand, Myanmar, the Malay Peninsula, Borneo, and Sumatra in Southeast Asia. Several recent studies have increased the diversity of fossil and living taxa described in the genus Scleropages. Pouyaud et al. (2003) named several new species of Scleropages based on coloration, slight meristic and morphometric differences, and slight mitochondrial variation; as noted above, these are widely held to be color variants of $S$. formosus and not accepted as valid (e.g., Kottelat, Widjanarti, 2005; Mohd-Shamsudin et al., 2011; Roberts, 2012; Kottelat, 2013). Scleropages inscriptus was described by Roberts (2012) from Myanmar, and diagnosed based on the presence of maze-like markings on the head and body, unlike the even coloration of S. formosus; it differs also in meristic and morphometric characters from the Australian Scleropages. There are significant taxonomic concerns regarding the Australian species of Scleropages as well, in that evidence suggests that $S$. leichardti was that the relatively general description provided by Günther (1864) was based on a specimen that is of unclear provenance but likely originated outside of its known range (i.e., the Fitzroy River basin) and has inconsistencies with current descriptions of $S$. leichardti (Pusey et al., 2016). Pusey et al. (2016) further suggest that close examination of the disjunct populations of $S$. jardinii are warranted to determine degree of separation and whether or not there is species-level distinction and structure within this species. Zhang, Wilson (2017) recently described $\dagger$ S. sinensis from the Early Eocene Xiwanpu and Yangxi formations of China based on well-preserved whole body fossils. This taxon was assigned to Scleropages based on overall similarities of the skull, caudal skeleton, fins, and scales to modern species of the genus. We do not dispute these similarities, but note that the cited characteristics (e.g., shape of fins and reticulate scales) are all plesiomorphic, at least to the level of Osteoglossidae. Indeed, no synapomorphies have yet been offered to support the genus Scleropages as a monophyletic group, and at least two studies (Taverne, 1998; Xu, Chang, 2009) have failed to recover its monophyly. Renewed study of the genus, including all taxa provisionally included, as well as robust outgroup sampling, is necessary to robustly define the genus Scleropages. 
Future directions for molecular systematics of Osteoglossomorpha. With the development of high throughput sequencing technology and the near-future possibility to sequence whole genome at reasonable cost (and the concomitant progresses in computer-based comparative methods), we are entering in a new area in fish systematics which will complete traditional approaches (morphological examination and low efficiency sequencing technology) and refine our understanding of the phylogeny (and evolution) of Osteoglossomorpha (Braasch et al., 2015). Three draft genomes of Osteoglossomorpha are already available, Scleropages formosus (Austin et al., 2015; Bian et al., 2016), Paramormyrops kingsleyae (Gallant et al., 2017) and Arapaima gigas (Vialle et al., 2018) and there are plans to sequence additional ones, such as that of Hiodon and Pantodon (Bernardi et al., 2012). Although as promising as each (including this one) new technological step can be with the comparison of extremely large genetic datasets, it is not expected this will be the "panacea" as already evidenced by the incongruent results presented by several genomic studies on the phylogenetic position of the Osteoglossomorpha (Austin et al., 2015; Faircloth et al., 2013; Chen et al., 2015; Bian et al., 2016; Hughes et al., 2018; Vialle et al., 2018). We anticipate that this overwhelming amount of genetic data will make more sense when they will be analyzed with existing and new phenotypic data (especially morphological data) from both extant and fossil taxa. In combining all the evidence, more reliable phylogenies will be produced.

Historical biogeography of Osteoglossomorpha. Phylogenetically based reconstruction of the evolution, including both pattern and process, of the distribution of the living Osteoglossomorpha within a changing paleo-geological and paleo-climatic context requires the combination of several lines of evidence - which are sometimes ambiguous or even in conflict - relative to their past geographical distribution (direct evidence from the fossil record plus inference), their past habitat preference relative to salinity and temperature (direct evidence from the fossil record plus inference) and the timing of diversification (direct evidence from the fossil record plus inference). As discussed above, there have been several attempts made to address these factors, both individually and in combination. However, there are numerous methods available that have not been employed for analyzing the historical biogeographic patterns exhibited by Osteoglossomorpha, including comparative, or cladistic, biogeography (e.g., Parenti, Ebach, 2009) and ancestral area analysis (Ree, Smith, 2008).

To illustrate one of possible directions for future investigation of the historical biogeography of the Osteoglossomorpha, we explored the potential of using a likelihood model, the dispersal-extinction-cladogenesis $+\mathrm{J}(\mathrm{DEC}+\mathrm{J})$ model (Matzke, 2013; Ree, Smith, 2008), to infer the evolution of geographic ranges within the Osteoglossomorpha. For this analysis we used the BioGeoBEARS v.0.2 R-package (Matzke, 2013) and the phylogenetic timetree of osteoglossomorpha obtained in
Lavoué (2016) (this work was published before the systematic reevaluation of $\dagger$ Joffrichthys and $\dagger$ Ostariostoma in Murray et al., 2018), which includes molecular and morphological characters and extant and extinct taxa. We consider a possible founder speciation event $(\mathrm{J})$ that allowed dispersal without range expansion at nodes (Matzke, 2013). We deleted the outgroup Elops. Six different geographical areas were considered in this analysis, each of them being delimited based on the continental distribution of the tip (extant and extinct) taxa of the tree (Fig. 18). The regions are: $\mathrm{A}-$ Afrotropics (= Africa), B - Neotropics (= South America), C - Orient (= Southeast Asia), D - Oceania (Australia and Papua-New Guinea), E Nearctics (= North America), and F - East Paleartics (= East Asia). No combination of areas was a priori excluded from the analysis. The maximum number of areas was set to five, corresponding to the maximum range occupied by the fossil $\dagger$ Phareodus and its closely allied forms of the extinct $\dagger$ Phareodontinae $(\mathrm{Li}$, Wilson, 1996a) (= "†Phareodontins" in the tree). All other taxa were restricted to one (or two for Scleropages and $\dagger$ Eohiodon) pre-defined areas.

Results show that the $(\mathrm{DEC}+\mathrm{J})$ model provided low support for ancestral area inference at the deepest nodes of the tree and within the family Osteoglossidae (Fig. 18). An ancestral area comprising only East Asia ("F") was inferred as the main place where the early diversification of the Osteoglossomorpha took place (including the most recent common ancestor, mrca) of the crown group Osteoglossomorpha, which lived during the Jurassic (about 190-150 Ma), though there is low support for this node. This reconstruction is in agreement with the hypothesis of Li (1997) and Greenwood (1970), who suggested that the most recent common ancestor of Osteoglossomorpha lived only in East Asia because the most ancient and morphologically primitive osteoglossomorphs known, such as $\dagger$ Lycoptera, came from this region. Hiodontidae (Hiodon plus $\dagger$ Eohiodon) experienced a first range extension from East Asia to Nearctics. Then two regional shifts are inferred with low support: a first shift from East Asia to Nearctics leading to the stem Osteoglossiformes, and a second shift from Nearctics to Africa (again with low support) leading to the crown Osteoglossiformes (excluding $\dagger$ Ostariostoma). After that, the central region of diversification of the Osteoglossiformes was Africa from where successive and independent events of dispersal to other regions occurred which were followed by intra-regional diversification (Notopterinae, $\dagger$ Joffrichthys, Arapaima, etc.). The model inferred rapid dispersal events with high likelihood between Africa and Southeast Asia to explain the distribution of notopterins. Finally, within the early osteoglossids, the model inferred large areas mostly driven by the condition coded for the "iphareodontins", with most of the ancestral area reconstructions at nodes receiving low likelihood support. Obviously, this attempt is far from complete, and we only present it to demonstrate the possibility of using a model-based approach to explore the biogeographic history of these fishes. This type of parametric approach may represent one direction for future studies of the historical biogeography of Osteoglossomorpha. 

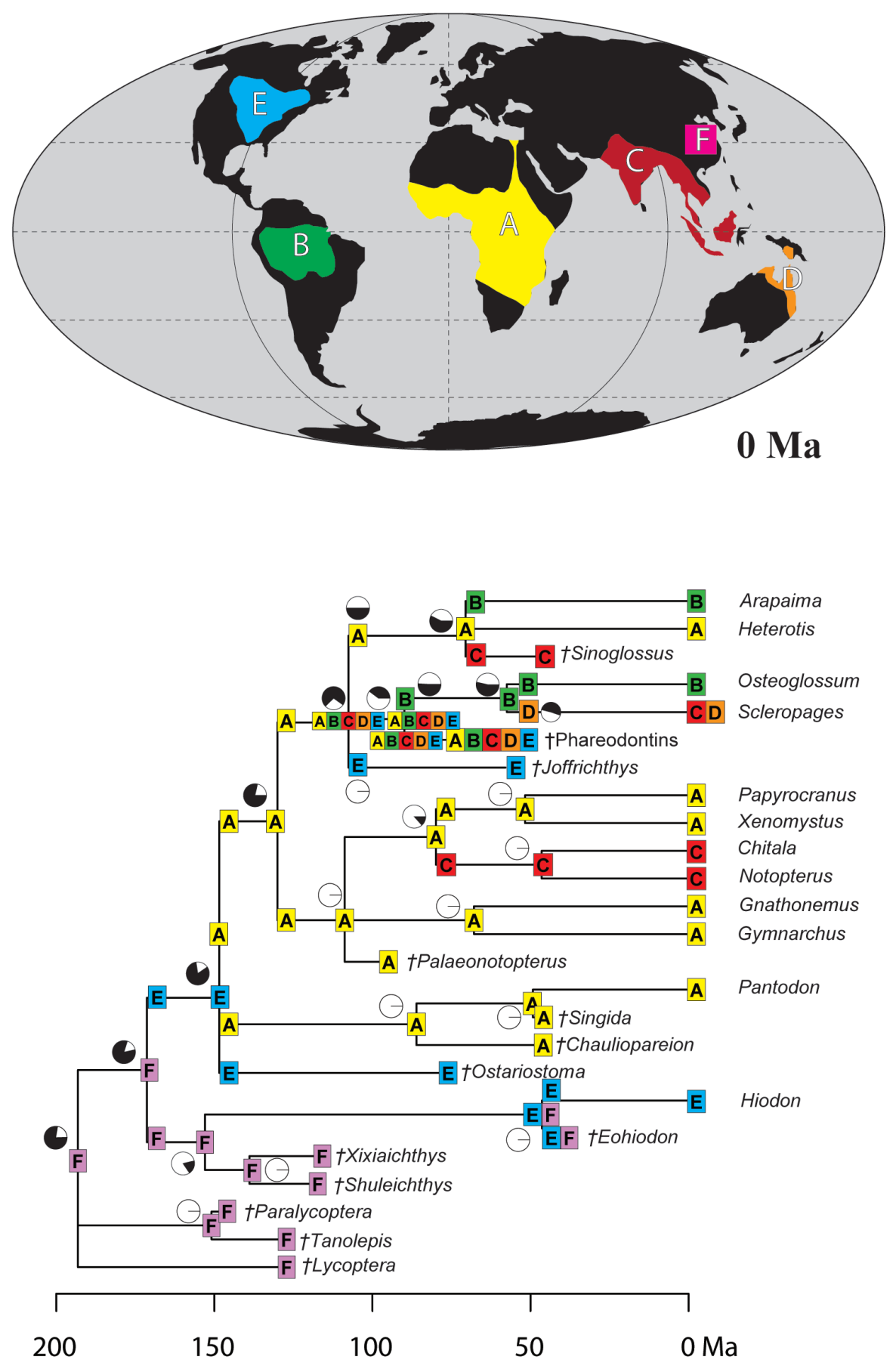

BioGeoBEARS model DEC $+J$

(ancstates: global optim, 5 areas max. $\mathrm{d}=6 \mathrm{e}-04 ; \mathrm{e}=0 ; \mathrm{j}=0.0403 ; \mathrm{LnL}=-51.93$ )

Fig. 18. Historical biogeography of Osteoglossomorpha based on ancestral area analysis (AAA). Ancestral area estimates under the unconstrained model DEC $+\mathrm{J}$ using the time-calibrated Bayesian phylogeny of Osteoglossomorpha of Lavoué (2016) that combines molecular and morphological characters and extant and extinct taxa. Letters from $\mathrm{A}$ to $\mathrm{F}$ represent the regions (see above map) used for the biogeographical reconstruction: A (yellow), Afrotropics; B (green) Neotropics; C (red) Orient; D (orange) Australia; E (blue) Nearctics, F (pink) North-Eastern Palearctics (Cretaceous period). The geographical distributions of extant and extinct taxa are indicated. The most likely ancestral range is provided: ancestral ranges at nodes indicate the inferred ancestral distributions before speciation and ancestral ranges at corner positions represent geographical ranges immediately after speciation. Black and white pie charts above specific ancestral area reconstruction show the probability (white) of the corresponding reconstruction. 


\section{Acknowledgments}

This paper is based on a presentation made by EJH at the II International Symposium on Phylogeny and Classification of Neotropical Fishes held at Londrina, Brazil (October 2017). EJH thanks the organizers of the meeting, and in particular José Birindelli and Fábio Di Dario for extending an invitation to present. We thank Casey Dillman (CUMV) for loan of specimens, Sarah Huber (VIMS) for curatorial assistance, and Zach Randall (FLMNH) for supplying photos used in Figs. 4 and 8. We thank Diego Vaz for providing a translation of the abstract. SL's contribution is supported by research grants MOST103-2119-M- 002-019-MY3 and MOST106-2119-M-002-032 from the Ministry of Science and Technology of Taiwan. This is contribution 3763 of the Virginia Institute of Marine Science, College of William \& Mary.

\section{References}

Agnèse JF, Bigorne R. Premières données sur les relations génétiques entre onze espèces ouest-africaines de Mormyridae (Teleostei, Osteichthyes). Rev Hydrobiol Trop. 1992; 25(3):253-61.

Akinyi E, Azeroual A, Entsua-Mensah M, Getahun A, Lalèyè P, Moelants T. Heterotis niloticus. The IUCN Red List of Threatened Species [Internet]. 2010 [cited 2018 Mar 09]: e.T182580A7920022. Available from: http://dx.doi. org/10.2305/IUCN.UK.2010-3.RLTS.T182580A7920022.en

Ali JR, Aitchison JC. Gondwana to Asia: Plate tectonics, paleogeography and the biological connectivity of the Indian sub-continent from the Middle Jurassic through latest Eocene (166-35 Ma). Earth-Sci Rev [serial on the Internet]. 2008; 88(3-4):145-66. Available from: https://doi.org/10.1016/j. earscirev.2008.01.007

Alves-Gomes JA. Systematic biology of gymnotiform and mormyriform electric fishes: phylogenetic relationships, molecular clocks and rates of evolution in the mitochondrial rRNA genes. J Exp Biol. 1999; 202(10):1167-83.

Alves-Gomes JA, Hopkins CD. Molecular insights into the phylogeny of mormyriform fishes and the evolution of their electric organ. Brain Behav Evol. 1997; 49(6):324-29.

Araripe J, do Rêgo PS, Queiroz H, Sampaio I, Schneider H. Dispersal capacity and genetic structure of Arapaima gigas on different geographic scales using microsatellite markers. PLoS One [serial on the Internet]. 2013; 8(1): e54470. Available from: https://doi.org/10.1371/journal.pone.0054470

Arnegard ME, McIntyre PB, Harmon LJ, Zelditch ML, Crampton WGR, Davis JK, Sullivan JP, Lavoué S, Hopkins CD. Sexual signal evolution outpaces ecological divergence during electric fish species radiation. Am Nat [serial on the Internet]. 2010; 176(3): 335-56. Available from: https://doi.org/10.1086/655221

Arratia G. The caudal skeleton of Jurassic teleosts: A phylogenetic analysis. In: Chang M-M, Liu H, Zhang G-R, editors. Early Vertebrates and Related Problems in Evolutionary Biology. Beijing: Science Press; 1991. p.249-340.

Arratia G. Basal teleosts and teleostean phylogeny. Palaeo Ichthyol. 1997; 7:5-168.

Arratia G. The monophyly of Teleostei and stem-group teleosts. Consensus and disagreements. In: Arratia G, Schultze H-P, editors. Mesozoic Fishes 2: Systematics and Fossil Record. München: Verlag Dr. Friedrich Pfeil; 1999. p.265-334.

Arratia G. The sister-group of Teleostei: Consensus and disagreements. J Vertebr Paleontol. 2001; 21(4):767-73.

Arratia, G. The vasarichthyid and other crossognathiform fishes, and the break-up of Pangea. In: Cavin L, Longbottom A, Richter M, editors. Fishes and the Break-up of Pangea. London: Geological Society; 2008. p.71-92. (Special Publications; 295).

Arratia G, Schultze H-P. Palatoquadrate and its ossifications: Development and homology within osteichthyans. J Morphol [serial on the Internet]. 1991; 208(1):1-81. Available from: https://doi.org/10.1002/jmor.1052080102

Austin CM, Tan MH, Croft LJ, Hammer MP, Gan HM. Whole genome sequencing of the Asian Arowana (Scleropages formosus) provides insights into the evolution of ray-finned fishes. Genome Biol Evol [serial on the Internet]. 2015; 7(10):2885-95. Available from: https://doi.org/10.1093/gbe/evv186

Azeroual A, Entsua-Mensah M, Getahun A, Lalèyè P, Moelants T, Vreven E. 2010. Gymnarchus niloticus. The IUCN Red List of Threatened Species [Internet]; 2010 [cited 2018 Feb 12]: e.T181688A7706153. Available from: http://dx.doi. org/10.2305/IUCN.UK.2010-3.RLTS.T181688A7706153.en

Bănărescu P. Zoogeography of Fresh Waters. Volume 2: distribution and dispersal of freshwater animals in North America and Eurasia. Wiesbaden: Aula-Verlag; 1991.

Battle HI, Sprules WM. A description of the semi-buoyant eggs and early developmental stages of the Goldeye, Hiodon alosoides (Rafinesque). Can J Fish Aquat Sci [serial on the Internet]. 1960; 17(2):245-66. Available from: https://doi.org/10.1139/ f60-020

de Beaufort LF. Notes on the distribution of freshwater fishes. Copeia [serial on the Internet]. 1964; 1964(1):60-65. Available from: http://jstor.org/stable/1440832

Benveniste L. Phylogenetic systematic of Gymnarchus (Notopteroidei) with notes on Petrocephalus (Mormyridae) of the Osteoglossomorpha. [Masters Thesis]. New York City, NY: The City College of New York; 1994.

Bergsten J. A review of long-branch attraction. Cladistics [serial on the Internet]. 2005; 21(2):163-93. Available from: https://doi. org/10.1111/j.1096-0031.2005.00059.x

Bernardi G, Wiley EO, Mansour H, Miller MR, Ortí G, Haussler D, O'Brien SJ, Ryder OA, Venkatesh B. The fishes of Genome 10K. Mar Genomics [serial on the Internet]. 2012; 7:3-6. Available from: https://doi.org/10.1016/j.margen.2012.02.002

Betancur-R R, Broughton RE, Wiley EO, Carpenter K, López JA, Li C, Holcroft NI, Arcila D, Sanciangco M, Cureton II JC, Zhang F, Buser T, Campbell MA, Ballesteros, JA, Roa-Varon A, Willis S, Borden WC, Rowley T, Reneau PC, Hough DJ, Lu G, Grande T, Arratia G, Orti G. The tree of life and a new classification of bony fishes. PLoS Curr [serial on the Internet]. 2013; 5:ecurrents.tol.53ba26640df0ccaee75bb165c8c26288. Available from: http://doi.org/10.1371/currents.tol.53ba26640 df0ccaee 75 bb $165 \mathrm{c} 8 \mathrm{c} 26288$

Betancur-R R, Wiley EO, Arratia G, Acero A, Bailly N, Miya M, Lecointre G, Ortí G. Phylogenetic classification of bony fishes. BMC Evol Biol [serial on the Internet]. 2017; 17(162):1-40. Available from: http://doi.org/10.1186/s12862-017-0958-3

Bian C, Hu YC, Ravi V, Kuznetsova IS, Shen XY, Mu XD, Sun Y, You XX, Li J, Li XF, Qiu Y, Tay BH, Thevasagayam NM, Komissarov AS, Trifonov V, Kabilov M, Tupikin A, Luo JR, Liu Y, Song HM, Liu C, Wang XJ, Gu DG, Yang YX, Li WJ, Polgar G, Fan GY, Zeng P, Zhang H, Xiong ZJ, Tang ZJ, Peng 
C, Ruan ZQ, Yu H, Chen JM, Fan MJ, Huang Y, Wang M, Zhao $\mathrm{XM}$, Hu GJ, Yang HM, Wang J, Wang X, Xu LS, Song GC, Xu P, Xu JM, O’Brien SJ, Orban L, Venkatesh B, Shi Q. The Asian arowana (Scleropages formosus) genome provides new insights into the evolution of an early lineage of teleosts. Sci Rep. [serial on the Internet]. 2016; 6(24501). Available from: http://doi.org/10.1038/srep24501

Bigorne R. Mormyridae. In: Lévêque C, Paugy D, Teugels GG, editors. Faune des poissons d'eaux saumâtres d'Afrique de l'Ouest. Tome 1. Tervuren: Musée Royal de l'Afrique Centrale, and Paris: ORSTOM; 1990. p.122-184.

Bloom DD, Lovejoy NR. Molecular phylogenetics reveals a pattern of biome conservatism in New World anchovies (family Engraulidae). J Evol Biol [serial on the Internet]. 2012; 25(4):701-15. Available from: https://doi.org/10.1111/j.14209101.2012.02464.x

Bonaparte CL. Catalogo metodico dei pesci europei. Part 2. Atti Sci Ital. 1846; 1-95.

Bonde N. Osteoglossids (Teleostei:Osteoglossomorpha) of the Mesozoic - Comments on their interrelationships. In: Arratia G, Viohl G, editors. Mesozoic Fishes: Systematics and Paleoecology. München: Verlag Dr. Friedrich Pfeil, 1996. p.273-284.

Bonde N. Osteoglossomorphs of the marine Lower Eocene of Denmark - with remarks on other Eocene taxa and their importance for palaeobiogeography. In: Cavin L, Longbottom A, Richter M, editors. Fishes and the Break-up of Pangea. London: Geological Society; 2008. p.253-310. (Special Publications; 295).

Boulenger GA. A revision of the genera and species of fishes of the family Mormyridae. Proc Zool Soc Lond; 1898; 66(4):775821.

Braasch I, Peterson SM, Desvignes T, McCluskey BM, Batzel P, Postlethwait JH. A new model army: Emerging fish models to study the genomics of vertebrate evo-devo. J Exp Zool B Mol Dev Evol. 2015; 324(4):316-41.

Bradford MR, Jr. African, but not Asian, notopterid fishes are electroreceptive: evidence from brain characters. Neurosci Lett [serial on the Internet]. 1982; 32(1):35-39. Available from: https://doi.org/10.1016/0304-3940(82)90225-7

Briggs JC. Fishes and birds: Gondwana life rafts reconsidered. Syst Biol [serial on the Internet]. 2003; 52(4):548-53. Available from: https://jstor.org/stable/3651142

Britz R. Egg structure and larval development of Pantodon buchholzi (Teleostei: Osteoglossomorpha), with a review of data on reproduction and early life history in other osteoglossomorphs. Ichthyol Explor Freshw. 2004; 15(3):209-24.

Carlson BA, Hasan SM, Hollmann M, Miller DB, Harmon LJ, Arnegard ME. Brain evolution triggers increased diversification of electric fishes. Science [serial on the Internet]. 2011; 332(6029):583-86. Available from: https://doi.org/10.1126/ science. 1201524

Cavin L. Palaeobiogeography of Cretaceous bony fishes (Actinistia, Dipnoi and Actinopterygii). In: Cavin L, Longbottom A, Richter M, editors. Fishes and the Break-up of Pangea. London: Geological Society; 2008. p.165-183. (Special Publications; 295).

Cavin L, Forey PL. Osteology and systematic affinities of Palaeonotopterus greenwoodi Forey 1997 (Teleostei: Osteoglossomorpha). Zool J Linn Soc [serial on the Internet]. 2001; 133(1):25-52. Available from: https://doi. org/10.1111/j.1096-3642.2001.tb00621.x
Cavin L, Forey PL, Giersch S. Osteology of Eubiodectes libanicus (Pictet \& Humbert, 1866) and some other ichthyodectiformes (Teleostei): phylogenetic implications. J Syst Palaeontol [serial on the Internet]. 2013; 11(2):115-77. Available from: https:// doi.org/10.1080/14772019.2012.691559

Cavin L, Longbottom A, Richter M, editors.Fishes and the Breakup of Pangaea. London: Geological Society; 2008. (Special Publications; 295).

Chang M-M, Chou C-C. [On Late Mesozoic fossil fishes from Zhejiang Province, China]. Mem Inst Vertebr Palaeontol Palaeoanthrop. 1977; 12:1-60. [in Chinese, with English summary].

Chatterjee S, Goswami A, Scotese CR. The longest voyage: Tectonic, magmatic, and paleoclimatic evolution of the Indian plate during its northward flight from Gondwana to Asia. Gondwana Res [serial on the Internet]. 2013; 23(1):238-67. Available from: https://doi.org/10.1016/j.gr.2012.07.001

Chen JN, López JA, Lavoué S, Miya M, Chen W-J. Phylogeny of the Elopomorpha (Teleostei): Evidence from six nuclear and mitochondrial markers. Mol Phylogenet Evol [serial on the Internet]. 2014; 70:152-61. Available from: https://doi. org/10.1016/j.ympev.2013.09.002

Chen M-Y, Liang D, Zhang P. Selecting question-specific genes to reduce incongruence in phylogenomics: A case study of jawed vertebrate backbone phylogeny. Syst Biol [serial on the Internet]. 2015; 64(6):1104-20. Available from: https://doi. org/10.1093/sysbio/syv059

Conway KW, Kim DM, Rüber L, Pérez HSE, Hastings PA. Molecular systematics of the New World clingfish genus Gobiesox (Teleostei: Gobiesocidae) and the origin of a freshwater clade. Mol Phylogenet Evol [serial on the Internet]. 2017; 112:138-47. Available from: https://doi.org/10.1016/j.ympev.2017.04.024

Cope ED. Observations on the systematic relations of the fishes. Am Nat. 1871; 5(8/9):579-93.

Cracraft J. Continental drift and vertebrate distribution. Annu Rev Ecol Syst [serial on the Internet]. 1974; 5(1):215-61. Available from: https://doi.org/10.1146/annurev.es.05.110174.001243

Darlington PJ. Zoogeography: The geographical distribution of animals. New York: John Wiley \& Sons; 1957.

Davis AM, Unmack PJ, Pusey BJ, Johnson JB, Pearson RG. Marine-freshwater transitions are associated with the evolution of dietary diversification in terapontid grunters (Teleostei: Terapontidae). J Evol Biol [serial on the Internet]. 2012; 25(6):1163-79. Available from: https://doi.org/10.1111/j.14209101.2012.02504.x

Eigenmann $\mathrm{CH}$. The origin of the fish-fauna of the fresh waters of south America. Boston: The University Press; 1912. (Proceedings of the Seventh International Zoological Congress, 19-24 August 1907).

Escobar L MD, Farias IP, Taphorn B DC, Landines M, Hrbek T. Molecular diagnosis of the arowanas Osteoglossum ferreirai Kanazawa, 1966 and O. bicirrhossum (Cuvier, 1829) from the Orinoco and Amazon River basins. Neotrop Ichthyol [serial on the Internet]. 2013; 11(2):335-40. Available from: https://doi. org/10.1590/S1679-62252013000200011

Faircloth BC, Sorenson L, Santini F, Alfaro ME. A phylogenomic perspective on the radiation of Ray-finned fishes based upon targeted sequencing of ultraconserved elements (UCEs). PLoS One [serial on the Internet]. 2013; 8(6):e65923. Available from: https://doi.org/10.1371/journal.pone.0065923

Feulner PGD, Kirschbaum F, Mamonekene V, Ketmaier V, Tiedemann R. Adaptive radiation in African weakly electric 
fish (Teleostei: Mormyridae: Campylomormyrus): a combined molecular and morphological approach. J Evol Biol [serial on the Internet]. 2007; 20(1):403-14. Available from: https://doi. org/10.1111/j.1420-9101.2006.01181.x

Forey PL. A Cretaceous notopterid (Pisces: Osteoglossomorpha) from Morocco. S Afr J Sci. 1997; 93(11-12):564-69.

Forey PL, Hilton EJ. Two new Tertiary osteoglossid fishes (Teleostei: Osteoglossomorpha) with notes on the history of the family. In: Elliott DK, Maisey JG, Yu X, Miao D, editors. Morphology, phylogeny and paleobiogeography of fossil fishes. München: Verlag Dr. Friedrich Pfeil; 2010. p.215-246.

Fowler HW. Descriptions of new fishes obtained 1907 to 1910 , chiefly in the Philippine Islands and adjacent seas. Proc Acad Nat Sci Phila [serial on the Internet]. 1933; 85:233-67. Available from: https://jstor.org/stable/4064176

Fricke R, Eschmeyer WN, Fong JD. Species by family/subfamily in the Catalog of Fishes. [Eletronic version]. San Francisco: California Academy of Sciences; 2018. [cited 2018 Feb 12]. Available from: http://researcharchive.calacademy.org/ research/ichthyology/catalog/SpeciesByFamily.asp

Friedman M, Keck BP, Dornburg A, Eytan RI, Martin CH, Hulsey CD, Wainwright PC, Near TJ. Molecular and fossil evidence place the origin of cichlid fishes long after Gondwanan rifting. Proc Roy Soc B Biol Sci. 2013; 280(1770):1-8. Available from: http://doi.org/10.1098/rspb.2013.1733

Gaina C, van Hinsbergen DJJ, Spakman W. Tectonic interactions between India and Arabia since the Jurassic reconstructed from marine geophysics, ophiolite geology, and seismic tomography. Tectonics [serial on the Internet]. 2015; 34(5):875-906. Available from: https://doi.org/10.1002/2014TC003780

Gallant JR, Losilla M, Tomlinson C, Warren WC. The genome and adult somatic transcriptome of the mormyrid electric fish Paramormyrops kingsleyae. Genome Biol Evol [serial on the Internet]. 2017; 9(12):3525-30. Available from: https://doi. org/10.1093/gbe/evx265

Garstang W. The phyletic classification of Teleostei. Proc Leeds Philos Lit Soc Sci Sect. 1931; 2(5):240-60.

Gayet M, Meunier FJ. Écailles actuelles et fossiles d'Ostéoglossiformes (Pisces, Teleostei). C R Acad Sci II. 1983; 297(13):867-70.

Gayet M, Meunier FJ. Maastrichtian to early late Paleocene freshwater Osteichthyes of Bolivia: additions and comments. In: Malabarba LR, Reis RE, Vari RP, Lucena ZMS, Lucena CAS, editors. Phylogeny and classification of Neotropical fishes. Porto Alegre: Edipucrs; 1998. p.85-110.

Gosline WA. Contribution toward a classification of modern isospondylous fishes. Bull Brit Mus (Nat Hist) Zool. 1960; 6(6):325-65.

Gosline WA. A reexamination of the similarities between the freshwater fishes of Africa and South America. Mem Mus Natn Hist Nat Paris. 1975; 88:146-54.

Goulding M. The fishes and the forest: explorations in Amazonian natural history. Berkeley and Los Angeles: University of California Press; 1980.

Grande L, Cavender TM. Description and phylogenetic reassessment of the monotypic Ostariostomidae (Teleostei). J. Vertebr Paleontol [serial on the Internet]. 1991; 11(4):405-16. Available from: https://doi.org/10.1080/02724634.1991.10011 412

Greenwood PH, Rosen DE, Weitzman SH, Myers GS. Phyletic studies of teleostean fishes, with a provisional classification of living forms. Bull Am Mus Nat Hist. 1966; 131(4):339-456.
Greenwood PH. On the genus Lycoptera and its relationship with the family Hiodontidae (Pisces, Osteoglossomorpha). Bull Brit Mus (Nat Hist) Zool. 1970; 19(8):259-85.

Greenwood PH. Hyoid and ventral gill arch musculature in osteoglossomorph fishes. Bull Brit Mus (Nat Hist) Zool. 1971; 22(1):1-55.

Greenwood PH. New fish fossils from Pliocene of Wadi Natrun Egypt. J Zool [serial on the Internet]. 1972; 168(4):503-19. Available from: https://doi.org/10.1111/j.1469-7998.1972.tb01364.x

Greenwood PH. Interrelationships of osteoglossomorphs. In: Greenwood PH, Miles RS, Patterson C, editors. Interrelationships of Fishes. London: Academic Press; 1973. p.307-332.

Günther ACLG. On a new generic type of fishes discovered by the late Dr. Leichardt in Queensland. J Nat Hist. 1864; 14(81):19597.

Hallam A. The bearing of certain palaeozoogeographic data on continental drift. Palaeogeogr Palaeoclimatol Palaeoecol [serial on the Internet]. 1967; 3:201-41. Available from: https:// doi.org/10.1016/0031-0182(67)90017-X

Hills ES. Tertiary fresh water fishes from southern Queensland. Mem Queensl Mus. 1934; 10(4):157-74.

Hills ES. Tertiary freshwater fishes and crocodilian remains from Gladstone and Duaringa, Queensland. Mem Queensl Mus. 1943; 12:96-100.

Hilton EJ. Tongue bite apparatus of osteoglossomorph fishes: Variation of a character complex. Copeia. 2001; 2001(2):37281.

Hilton EJ. Osteology of the extant North American fishes of the genus Hiodon Lesueur 1818 (Teleostei: Osteoglossomorpha: Hiodontiformes). Fieldiana Zool. 2002; 100:1-142.

Hilton EJ. Comparative osteology and phylogenetic systematics of fossil and living bony-tongue fishes (Actinopterygii, Teleostei, Osteoglossomorpha). Zool J Linn Soc [serial on the Internet]. 2003; 137(1):1-100. Available from: https://doi.org/10.1046/ j.1096-3642.2003.00032.x

Hilton EJ, Britz R. The caudal skeleton of osteoglossomorph fishes, revisited: comparisons, homologies, and characters. In: Nelson JS, Schultze H-P, Wilson MVH, editors. Origin and phylogenetic interrelationships of teleosts. München: Verlag Dr. Friedrich Pfeil; 2010. p.219-237.

Hilton EJ, Forey PL. Contributions of Walter G. Ridewood to systematic comparative anatomy, especially of the osteology of "lower" vertebrates. J Nat Hist [serial on the Internet]. 2005; 39(8):641-55. Available from: https://doi. org/10.1080/00222930400001475

Hilton EJ, Grande L. Fossil Mooneyes (Teleostei: Hiodontiformes, Hiodontidae) from the Eocene of western North America, with a reassessment of their taxonomy. In: Cavin L, Longbottom A, Richter M, editors. Fishes and the Break-up of Pangea. London: Geological Society; 2008. p.221-251. (Special Publications; 295).

Hilton EJ, Britz R, Johnson GD, Foley PL. Clarification of the OccipitoVertebral region of Arapaima gigas (Osteoglossomorpha: Osteoglossidae) through developmental osteology. Copeia. 2007; 2007(1):218-24.

Hilton EJ, Bemis WE, Grande L. Hiodontidae - Mooneyes. In: Burr B, Warren M, editors. North American freshwater fishes: evolution, ecology, and behavior, Volume 1. Baltimore: Johns Hopkins University Press; 2014. p.299-312.

Hilton EJ, Schnell NK, Konstantinidis P. When tradition meets technology: systematic morphology of fishes in the early 21 st century. Copeia. 2015; 103(4):858-73. 
Hrbek T, Farias IP, Crossa M, Sampaio I, Porto JIR, Meyer A. Population genetic analysis of Arapaima gigas, one of the largest freshwater fishes of the Amazon basin: implications for its conservation. Anim Conserv [serial on the Internet]. 2005; 8(3):297-308. Available from: https://doi.org/10.1017/ S1367943005002210

Hughes LC, Ortí G, Huang Y, Sun Y, Baldwin CC, Thompson AW, Arcila D, Betancur-R R, Li CH, Becker L, Bellora N, Zhao XM, Li XF, Wang M, Fang C, Xie B, Zhou ZC, Huang $\mathrm{H}$, Chen SL, Venkatesh B, Shi Q. Comprehensive phylogeny of ray-finned fishes (Actinopterygii) based on transcriptomic and genomic data. Proc Natl Acad Sci USA [serial on the Internet]. 2018; 115(24):6249-54. Available from: https://doi. org/10.1073/pnas.1719358115

Hurley IA, Mueller RL, Dunn KA, Schmidt EJ, Friedman M, Ho RK, Prince VE, Yang Z, Tomas MG, Coates MI. A new timescale for ray-finned fish evolution. Proc Roy Soc B [serial on the Internet]. 2007; 274(1609):489-98. Available from: https:// doi.org/10.1098/rspb.2006.3749

Hurtado LA, Carrera E, Adite A, Winemiller KO. Genetic differentiation of a primitive teleost, the African bonytongue Heterotis niloticus, among river basins and within a floodplain river system in Benin, West Africa. J Fish Biol [serial on the Internet]. 2013; 83(3):682-90. Available from: https://doi. org/10.1111/jfb. 12198

International Commission on Zoological Nomenclature (ICZN). International Code of Zoological Nomenclature. 4th ed. London: International Trust for Zoological Nomenclature Natural History Museum; 1999.

Inoue JG, Kumazawa Y, Miya M, Nishida M. The historical biogeography of the freshwater knifefishes using mitogenomic approaches: A Mesozoic origin of the Asian notopterids (Actinopterygii: Osteoglossomorpha). Mol Phylogent Evol [serial on the Internet]. 2009; 51(3):486-99. Available from: https://doi.org/10.1016/j.ympev.2009.01.020

Inoue JG, Miya M, Tsukamoto K, Nishida M. Basal actinopterygian relationships: a mitogenomic perspective on the phylogeny of the "ancient fish". Mol Phylogent Evol [serial on the Internet]. 2003; 26(1):110-20. Available from: https://doi.org/10.1016/ S1055-7903(02)00331-7

Jin F. A new genus and species of Hiodontidae from Xintai, Shandong. Vert PalAs. 1991; 29(1):46-54. [In Chinese with an English summary].

Jin F, Zhang J, Zhou Z. Late Mesozoic fish fauna from western Liaoning, China. Vert PalAs, 1995; 33(3):169-93. [In Chinese with an English summary].

Johnson GD, Ida H, Sakaue J, Sado T, Asahida T, Miya M. A 'living fossil' eel (Anguilliformes: Protanguillidae, fam. nov.) from an undersea cave in Palau. Proc R Soc Lon B Biol Sci [serial on the Internet]. 2012; 279(1730):934-43. Available from: https:// doi.org/10.1098/rspb.2011.1289

Kottelat M. The fishes of the inland waters of Southeast Asia: a catalogue and core bibliography of the fishes known to occur in freshwaters, mangroves and estuaries. Raffles Bull Zool. 2013; 27:1-663.

Kottelat M, Widjanarti E. The fishes of Danau Sentarum National Park and the Kapuas Lakes area, Kalimantan Barat, Indonesia. Raffles Bull Zool. 2005; 13:139-73.

Kumar K, Rana RS, Paliwal BS. Osteoglossid and lepisosteid fish remains from the Paleocene Palana Formation, Rajasthan, India. Pap Palaeontol [serial on the Internet]. 2005; 48(6):1187-1209. Available from: https://doi.org/10.1111/j.1475-4983.2005.00519.x
Kumazawa Y, Nishida M. Molecular phylogeny of osteoglossoids: a new model for Gondwanian origin and plate tectonic transportation of the Asian arowana. Mol Biol Evol [serial on the Internet]. 2000; 17(12):1869-78. Available from: https:// doi.org/10.1093/oxfordjournals.molbev.a026288

Lauder GV, Liem KF. The evolution and interrelationships of the actinopterygian fishes. Bull Mus Comp Zool. 1983; 150(3):95197.

Lavoué S. Testing a time hypothesis in the biogeography of the arowana genus Scleropages (Osteoglossidae). J Biogeog [serial on the Internet]. 2015; 42(12):2427-39. Available from: https:// doi.org/10.1111/jbi.12585

Lavoué S. Was Gondwanan breakup the cause of the intercontinental distribution of Osteoglossiformes? A time-calibrated phylogenetic test combining molecular, morphological, and paleontological evidence. Mol Phylogenet Evol [serial on the Internet]. 2016; 99:34-43. Available from: https://doi. org/10.1016/j.ympev.2016.03.008

Lavoué S, Bigorne R, Lecointre G, Agnèse JF. Phylogenetic relationships of mormyrid electric fishes (Mormyridae, Teleostei) inferred from cytochrome $b$ sequences. Mol Phylogenet Evol [serial on the Internet]. 2000; 14(1):1-10. Available from: https://doi.org/10.1006/mpev.1999.0687

Lavoué S, Miya M, Arnegard ME, McIntyre PB, Mamonekene V, Nishida M. Remarkable morphological stasis in an extant vertebrate despite tens of millions of years of divergence. Proc R Soc Long B Biol Sci [serial on the Internet]. 2011; 278:100308. Available from: https://doi.org/10.1098/rspb.2010.1639

Lavoué S, Miya M, Arnegard ME, Sullivan JP, Hopkins CD, Nishida M. Comparable ages for the independent origins of electrogenesis in African and South American weakly electric fishes. PLoS One [serial on the Internet]. 2012; 7(e36287). Available from: https://doi.org/10.1371/journal.pone.0036287

Lavoué S, Miya M, Musikasinthorn P, Chen W-J, Nishida M. Mitogenomic evidence for an Indo-West Pacific origin of the Clupeoidei (Teleostei: Clupeiformes). PLoS One [serial on the Internet]. 2012; 7(5):e56485. Available from: https://doi. org/10.1371/journal.pone.0056485

Lavoué S, Sullivan JP. Simultaneous analysis of five molecular markers provides a well-supported phylogenetic hypothesis for the living bony-tongue fishes (Osteoglossomorpha: Teleostei). Mol Phylogenet Evol [serial on the Internet]. 2004. 33(1):171-85. Available from: https://doi.org/10.1016/j. ympev.2004.04.021

Le HLV, Lecointre G, Perasso R. A 28S rRNA-based phylogeny of the gnathostomes: first steps in the analysis of conflict and congruence with morphologically based cladograms. Mol Phylogenet Evol [serial on the Internet]. 1993; 2(1):31-51. Available from: https://doi.org/10.1006/mpev.1993.1005

Leal MEC, Brito PM. Intraspecific variation of the caudal fin skeleton in Osteoglossum bicirrhosum Cuvier 1829 (Teleostei: Osteoglossomorpha: Osteoglossidae). Zootaxa [serial on the Internet]. 2007; 1434(1):1-26. Available from: https://doi. org/10.11646/zootaxa.1434.1.1

Leis JM, Olney JE, M Okiyama. Introduction to the proceedings of the symposium Fish Larvae and Systematics: Ontogeny and Relationships. Bull Mar Sci. 1997; 60(1):1-5.

Levin BA, Golubtsov AS. New insights into the molecular phylogeny and taxonomy of mormyrids (Osteoglossiformes, Actinopterygii) in northern East Africa. J Zool Syst Evol Res [serial on the Internet]. 2018. 56(1):61-76. Available from: https://doi.org/10.1111/jzs.12186 
Li CH, Lu GQ, Ortí G. Optimal data partitioning and a test case for ray-finned fishes (Actinopterygii) based on ten nuclear loci. Syst Biol [serial on the Internet]. 2008; 57(4):519-39. Available from: https://doi.org/10.1080/10635150802206883

Li G-Q. Notes on the historical biogeography of the Osteoglossomorpha (Teleostei). In: Jin Y-G, Dineley D, editors. Palaentology and historical geology. Proc 30th Int'1 Geo Congr. Utrecht: VSP BV; 1997. p.54-66. (Vol. 12)

Li G-Q, Wilson MVH. Phylogeny of Osteoglossomorpha. In: Stiassny MLJ, Parenti LR, Johnson GD, editors. Interrelationships of fishes. New York: Academic Press; 1996a. p.163-174.

Li G-Q, Wilson MVH. The discovery of Heterotidinae (Teleostei: Osteoglossidae) from the Paleocene paskapoo formation of Alberta, Canada. J Vertebr Paleontol [serial on the Internet]. 1996b. 16(2):198-209. Available from: https://doi.org/10.1080 /02724634.1996.10011308

Li G-Q, Wilson MVH. Early divergence of Hiodontiformes sensu stricto in East Asia and phylogeny of some Late Mesozoic teleosts from China. In: Arratia G, Schultze H-P, editors. Mesozoic fishes 2: systematics and fossil record. München: Verlag Dr. Friedrich Pfeil; 1999. p.369-384.

Li G-Q, Wilson MVH, Grande L. Review of Eohiodon (Teleostei: Osteoglossomorpha) from Western North America, with phylogenetic reassessment of Hiodontidae. J Paleontol [serial on the Internet]. 1997a; 71(6):1109-24. Available from: https:// doi.org/10.1017/S0022336000036064

Li G-Q, Grande L, Wilson MVH. The species of Phareodus (Teleostei: Osteoglossidae) from the Eocene of North America and their phylogenetic relationships. J Vert Paleontol [serial on the Internet]. 1997b; 17(3):487-505. Available from: https:// doi.org/10.1080/02724634.1997.10010997

Lundberg JG. African-South American freshwater fish clades and continental drift: problems with a paradigm. In: Goldblatt P, editor. Biological relationships between Africa and South America. New Haven: Yale University Press. 1993; p.156-199.

Lundberg JG, Chernoff B. A Miocene fossil of the Amazonian fish Arapaima (Teleostei, Arapaimidae) from the Magdalena River region of Colombia-Biogeographic and evolutionary implication. Biotropica [serial on the Internet]. 1992; 24(1):214. Available from: https://www.jstor.org/stable/2388468

Lundberg JG, Sullivan JP, Rodiles-Hernández R, Hendrickson DA. Discovery of African roots for the Mesoamerican Chiapas catfish, Lacantunia enigmatica, requires an ancient intercontinental passage. Proc Acad Nat Sci Phila [serial on the Internet]. 2007; 156:39-53. Available from: http://www.bioone. org/doi/abs/10.1635/0097-3157(2007)156\%5B39:DOARFT\% 5D2.0.CO\%3B2

Ma F-Z, Sun J-R. Jura-Cretaceous ichthyofaunas from the Sankeyushu section of Tonghua, Jilin. Acta Palaeont Sin. 1988; 27(6): 694-711. [In Chinese with English Summary].

Matschiner M, Musilová Z, Barth JMI, Starostová Z, Salzburger W, Steel M, Bouckaert R. Bayesian phylogenetic estimation of clade ages supports trans-Atlantic dispersal of cichlid fishes. Syst Biol [serial on the Internet]. 2017; 66(1):3-22. Available from: https://doi.org/10.1093/sysbio/syw076

Matzke NJ. Probabilistic historical biogeography: new models for founder-event speciation, imperfect detection, and fossils allow improved accuracy and model-testing [PhD Thesis]. Berkeley: University of California; 2013.

Mohd-Shamsudin MI, Fard MZ, Mather PB, Suleiman Z, Hassan R, Othman RY, Bhassu S. Molecular characterization of relatedness among colour variants of Asian Arowana (Scleropages formosus). Gene [serial on the Internet]. 2011; 490(1-2):47-53. Available from: https://doi.org/10.1016/j. gene.2011.08.025

Moritz T, Britz R. Ontogeny and homology of the basipterygoid articulation in Pantodon buchholzi (Teleostei: Osteoglossomorpha). Zool J Lin Soc [serial on the Internet]. 2005; 144:1-13. Available from: https://doi.org/10.1111/j.10963642.2005.00163.x

Mu XD, Gu DE, Yang YX, Luo D, Meng X, Wang XJ, Hu YC, Luo JR. Genetic diversity and phylogeny of the family Osteoglossidae by the nuclear $18 \mathrm{~S}$ ribosomal RNA and implications for its conservation. Biochem Syst Ecol [serial on the Internet]. 2013; 51:280-87. Available from: https://doi. org/10.1016/j.bse.2013.09.010

Mu XD, Wang XJ, Song HM, Yang YX, Luo D, Gu DE, Xu M, Liu $\mathrm{C}$, Luo JR, Hu YC. Mitochondrial DNA as effective molecular markers for the genetic variation and phylogeny of the family Osteoglossidae. Gene [serial on the Internet]. 2012; 511(2):32025. Available from: https://doi.org/10.1016/j.gene.2012.09.087

Murray AM, Newbrey MG, Neuman AG, Brinkman DB. New articulated osteoglossomorph from Late Cretaceus freshwater deposits (Maastrichtian, Scollard Formation) of Alberta, Canada. J. Vertebr Paleontol [serial on the Internet]. 2016; 36(4):e1120737. Available from: https://doi.org/10.1080/0272 4634.2016.1120737

MurrayAM, Wilson MVH. Description of a new Eocene osteoglossid fish and additional information on Singida jacksonoides Greenwood and Patterson, 1967 (Osteoglossomorpha), with an assessment of their phylogenetic relationships. Zool J Linn Soc [serial on the Internet]. 2005; 144(2):213-28. Available from: https://doi.org/10.1111/j.1096-3642.2005.00170.x

Murray AM, You HL, Peng C. A New Cretaceous osteoglossomorph fish from Gansu Province, China. J Vertebr Paleontol [serial on the Internet]. 2010; 30(2):322-32. Available from: https://doi. org/10.1080/02724631003621961

Murray AM, Zelenitsky DK, Brinkman DB, Neuman AG. Two new Palaeocene osteoglossomorphs from Canada, with a reassessment of the relationships of the genus Joffrichthys, and analysis of diversity from articulated versus microfossil material. Zool J Linn Soc [serial on the Internet]. 2018; 183(4):907-44. Available from: https://doi.org/10.1093/ zoolinnean/zlx 100

Near TJ, Eytan RI, Dornburg A, Kuhn KL, Moore JA, Davis MP, Wainwright PC, Friedman M, Smith WL. Resolution of rayfinned fish phylogeny and timing of diversification. Proc Natl Acad Sci USA [serial on the Internet]. 2012; 109(34): 13698703. Available from: https://doi.org/10.1073/pnas.1206625109

Nelson GJ. Gill arches of teleostean fishes of the division Osteoglossomorpha. J Linn Soc [serial on the Internet]. 1968; 47(312):261-77. Available from: https://doi. org/10.1111/j.1096-3642.1968.tb00511.x

Nelson GJ. Infraorbital bones and their bearing on the phylogeny and geography of osteoglosomorph fishes. Am Mus Novit. 1969; 2394:1-37.

Nelson GJ, Ladiges PY. Gondwana, vicariance biogeography and the New York School revisited. Aust J Bot. 2001; 49(3):389409.

Nelson JS. Fishes of the world. 3rd ed. New York (NY): J. Wiley; 1994.

Nelson JS. Fishes of the world. 4th ed. Hoboken (NJ): J. Wiley; 2006. 
Nelson JS, Grande TC, Wilson MVH. Fishes of the world. 5th ed. Hoboken (NJ): J. Wiley; 2016.

Nolf D, Rana RS, Prasad GVR. Late Cretaceous (Maastrichtian) fish otoliths from the Deccan Intertrappean Beds, India: a revision. Bull Inst R Sci Nat Belg Sci Terre. 2008; 78:239-59.

Normark BB, McCune AR, Harrison RG. Phylogeneticrelationships of Neopterygian fishes, inferred from mitochondrial DNA sequences. Mol Biol Evol [serial on the Internet]. 1991; 8(6):819-34. Available from: https://doi. org/10.1093/oxfordjournals.molbev.a040685

Otero O, Gayet M. Palaeoichthyofaunas from the Lower Oligocene and Miocene of the Arabian Plate: palaeoecological and palaeobiogeographical implications. Palaeogeogr Palaeoclimatol Palaeoecol [serial on the Internet]. 2001; 165(12):141-69. Available from: https://doi.org/10.1016/S00310182(00)00158-9

Otero O, Pinton A, Mackaye HT, Likius A, Vignaud P, Brunet M. First description of a Pliocene ichthyofauna from Central Africa (site KL2, Kolle area, Eastern Djurab, Chad): What do we learn?. J Afr Earth Sci [serial on the Internet]. 2009; 54(3-4):62-74. Available from: https://doi.org/10.1016/j. jafrearsci.2009.03.004

Parenti LR, Ebach MC. Comparative biogeography. Discovering and classifying biogeographical patterns of a dynamic earth. Berkeley and Los Angeles: University of California Press; 2009.

Patterson C. The distribution of Mesozoic freshwater fishes. Mem Mus Natn Hist Nat Paris. 1975; 88:155-74.

Patterson C. The contribution of paleontology to teleostean phylogeny. In: Hecht MK, Goody PC, Hecht BM, editors. Major patterns in vertebrate evolution. New York: Plenum Publishing Corporation; 1977. p.579-643.

Patterson C. The development of the North American fish fauna - a problem of historical biogeography. In: Forey PL, editor. Chance, Change and Challenge (vol. 2). The Evolving Biosphere. London: Cambridge University Press. 1981; p.265281.

Patterson C, Rosen DE. Review of ichthyodectiform and other Mesozoic teleost fishes and the theory and practice of classifying fossils. Bull Am Mus Nat Hist. 1977; 158(2):81172.

Pouyaud L, Sudarto, Teugels GG. The different colour varieties of the Asian Arowana Scleropages formosus (Osteoglossidae) are distinct species: morphologic and genetic evidences. Cybium. 2003; 27(4):287-305.

Pusey BJ, Fisher C, Maclaine J. On the nature of Scleropages leichardti Günther, 1864 (Pisces: Osteoglossidae). Zootaxa [serial on the Internet]. 2016; 4173(1):75-84. Available from: https://doi.org/10.11646/zootaxa.4173.1.7

Ree RH, Smith SA. Maximum likelihood inference of geographic range evolution by dispersal, local extinction, and cladogenesis. Syst Biol [serial on the Internet]. 2008; 57(1):4-14. Available from: https://doi.org/10.1080/10635150701883881

Regan CT. The distribution of the fishes of the order Ostariophysi. Bijdr Dierkd. 1922; 22(1):203-08.

Ridewood WG. On the cranial osteology of the fishes of the families Mormyridae, Notopteridae and Hiodontidae. J Linn Soc [serial on the Internet]. 1904; 29(190):188-217. Available from: https://doi.org/10.1111/j.1096-3642.1904.tb00435.x

Ridewood WG. On the cranial osteology of the fishes of the families Osteoglossidae, Pantodontidae, and Phractolaemidae. J Linn Soc [serial on the Internet]. 1905; 29(191):252-82. Available from: https://doi.org/10.1111/j.1096-3642.1905.tb00041.x

Roberts TR. Systematic revision of the old world freshwater fish family Notopteridae. Ichthyol Explor Freshw. 1992; 2(4):36183.

Roberts TR. Scleropages inscriptus, a new fish species from the Tananthayi or Tenasserim River basin, Malay Peninsula of Myanmar (Osteoglossidae: Osteoglossiformes). Aqua. 2012; 18(2):113-18.

Sanders M. Die fossilen Fische der Alttertiären Süsswasserablagerungen aus mittel-Sumatra. Verhandel Geol-mijnbouwk Genootsch Nederl Kolon. 1934; 11:1-144. (Geologische series).

Santini F, Harmon LJ, Carnevale G, Alfaro ME. Did genome duplication drive the origin of teleosts? A comparative study of diversification in ray-finned fishes. BMC Evol Biol [serial on the Internet]. 2009; 9(194):1-15. Available from: https://doi. org/10.1186/1471-2148-9-194

Schultze H-P; Arratia G. Reevaluation of the caudal skeleton of some actinopterygian fishes: II. Hiodon, Elops, and Albula. J Morphol [serial on the Internet]. 1988; 195(3):257-303. Available from: https://doi.org/10.1002/jmor.1051950304

Seton M, Müller RD, Zahirovic S, Gaina C, Torsvik TH, Shephard G, Talsma A, Gurnis M, Turner M, Maus S, Chandler M. Global continental and ocean basin reconstructions since 200 Ma. Earth Sci Rev [serial on the Internet]. 2012; 113(3-4):212-70. Available from: https://doi.org/10.1016/j. earscirev.2012.03.002

Shen M. Fossil "osteoglossomorphs" from East Asia and their implications for teleostean phylogeny. In: Arratia G, Viohl G, editors. Mesozoic Fishes: Systematics and Paleoecology. München: Verlag Pfeil; 1996. p.261-272.

Shen X-X, Hittinger CT, Rokas A. Contentious relationships in phylogenomic studies can be driven by a handful of genes. Nature Ecol Evol [serial on the Internet]. 2017; 1(126):1-10. Available from: https://doi.org/10.1038/s41559-017-0126

Snyder DE, Douglas SC. Description and identification of Mooneye, Hiodon tergisus, protolarvae. Trans Am Fish Soc [serial on the Internet]. 1978; 107(4):590-94. Available from: https://doi.org/10.1577/1548-8659(1978)107<590:DAIOMH> 2.0.CO;2

Sparks JS, Smith WL. Freshwater fishes, dispersal ability, and nonevidence: "Gondwana Life Rafts" to the rescue. Syst Biol [serial on the Internet]. 2005; 54(1):158-65. Available from: https://doi.org/10.1080/10635150590906019

Stewart DJ. Re-description of Arapaima agassizii (Valenciennes), a rare fish from Brazil (Osteoglossomorpha: Osteoglossidae). Copeia. 2013a; 2013(1):38-51.

Stewart DJ. A new species of Arapaima (Osteoglossomorpha: Osteoglossidae) from the Solimoes River, Amazonas State, Brazil. Copeia. 2013b; 2013(3):470-76.

Stiassny MLJ, Teugels GG, Hopkins CD, editors. Poissons d'eaux douces et saumâtres de basse Guinée, ouest de l'Afrique centrale. Vol. 2.. Paris: IRD, Publication Scientifique du Muséum, MRAC; 2007. (Faune et Flore Tropicales, 42).

Su D-Z. The discovery of a fossil osteoglossid fish in China. Vert PalAs, 1986; 24(1):10-19. [In Chinese with English summary].

Sullivan JP, Lavoué S, Arnegard ME, Hopkins CD. AFLPs resolve phylogeny and reveal mitochondrial introgression within a species flock of African electric fish (Mormyroidea: Teleostei). Evolution [serial on the Internet]. 2004; 58(4):82541. Available from: https://doi.org/10.1111/j.0014-3820.2004. tb00415.x 
Sullivan JP, Lavoué S, Hopkins CD. Molecular systematics of the African electric fishes (Mormyroidea: Teleostei) and a model for the evolution of their electric organs. J Exp Biol. 2000; 203(4):665-83

Sullivan JP, Lavoué S, Hopkins CD. Cryptomyrus: a new genus of Mormyridae (Teleostei, Osteoglossomorpha) with two new species from Gabon, West-Central Africa. Zookeys [serial on the Internet]. 2016; 561:117-50. Available from: https://doi. org/10.3897/zookeys.561.7137

Sullivan JP, Lavoué S, Hopkins CD. Discovery and phylogenetic analysis of a riverine species flock of African electric fishes (Mormyridae: Teleostei). Evolution [serial on the Internet]. 2002; 56(3):597-616. Available from: https://doi. org/10.1111/j.0014-3820.2002.tb01370.x

Taverne L. Le squelette caudal des Mormyriformes et des Ostéoglossomorphes. Acad Roy Belg Bull Cl Sc, Sér 5. 1967; 53(6):663-78.

Taverne L. Ostéologie du genre Gnathonemus Gill sensu stricto (Gnathonemus petersii (Gthr) et espèces voisines) (Pisces Mormyriformes). Ann Musee Roy Afr Centr Sci Zool. 1968a; 170:1-44.

Taverne L. Ostéologie du genre Campylomormyrus Bleeker (Pisces Mormyriformes). Ann Soc Roy Zool Belg. 1968b; 98(3):1-41.

Taverne L. Étude ostéologie des genres Boulengeromyrus Taverne and Géry, Genyomyrus Boulenger, Petrocephalus Marcusen (Pisces Mormyriformes). Ann Musee Roy Afr Centr Sci Zool. 1969; 174:1-85.

Taverne L. Note sur l'ostéologie du genre Gymnarchus Cuvier (Pisces Mormyriformes). Acad Roy Bel Bull Cl Sci. 1970; 56(1):63-78.

Taverne L. Ostéologie des genres Marcusenius Gill, Hippopotamyrus Pappenheim, Cyphomyrus Myers, Pollimyrus Taverne et Brienomyrus Taverne (Pisces Mormyriformes). Ann Musee Roy Afr Centr Sci Zool. 1971; 188:1-144.

Taverne L. Ostéologie des genres Mormyrus Linné, Mormyrops Müller, Hyperopisus Gill, Myomyrus Boulenger, Stomatorhinus Boulenger et Gymnarchus Cuvier. Considérations générales sur la systématique des Poissons de l'ordre des Mormyriformes. Ann Musee Roy Afr Centr Sci Zool. 1972; 200:1-194.

Taverne L. Ostéologie, phylogénèse et systématique des téléostéens fossiles et actuels du super-ordre des Ostéoglossomorphes: Ostéologie des genres Hiodon, Eohiodon, Lycoptera, Osteoglossum, Scleropages, Heterotis et Arapaima. Acad Roy Belg Mém Cl Sci Coll. 1977; 42(3):1-235. (Collection 8, Serie 2).

Taverne L. Ostéologie, phylogénèse, et systématique des téléostéens fossiles et actuels du super-ordre des ostéoglossomorphes, deuxième partie. Ostéologie des genres Phareodus, Phareoides, Brychaetus, Musperia, Pantodon, Singida, Notopterus, Xenomystus et Papyrocranus. Acad Roy Belg Mém Cl Sci. 1978; 42(6):1-213. (Collection 8, Serie 2).

Taverne L. Ostéologie, phylogenèse et systématique des téléostéens fossiles et actuels du super ordre des Ostéoglossomorphes. Troisième partie. Evolution des structures ostéologiques et conclusions générales relatives à la phylogenèse et à la systématique du super ordre. Acad Roy Belg Mém Cl Sci. 1979; 43(3):1-168. (Collection 8, Serie 2)

Taverne L. Les Ostéoglossomorphes marins de. l'Eocène du Monte Bolca (Italie): Monopteros Volta 1796, Thrissopterus Heckel, 1856 et Foreyichthys Taverne, 1979. Considérations sur la phylogénie des Téléostéens ostéoglossomorphes. Stud Ric Giacimenti Terziari Bolca. 1998; 7:67-158.
Taverne L. Ridewoodichthys, a new genus for Brychaetus caheni from the marine Paleocene of Cabinda (Africa): Re-description and comments on its relationships within the Osteoglossidae (Teleostei, Osteoglossomorpha). Bull Inst R Sci Nat Belg Sci Terre. 2009a; 79:147-53

Taverne L. New insights on the osteology and taxonomy of the osteoglossid fishes Phareodus, Brychaetus and Musperia (Teleostei, Osteoglossomorpha). Bull Inst R Sci Nat Belg Sci Terre. 2009b; 79:175-90.

Taverne L. On the presence of the osteoglossid genus Scleropages in the Paleocene of Niger, Africa (Teleostei, Osteoglossomorpha). Bull Inst R Sci Nat Belg Sci Terre. 2009c; 79:161-67.

Taverne L, Kumar K, Rana RS. Complement to the study of the Indian Paleocene osteoglossid fish genus Taverneichthys (Teleostei, Osteoglossomorpha). Bull Inst R Sci Nat Belg Sci Terre. 2009; 79:155-60.

Taverne L, Maisey JG. A notopterid skull (Teleostei, Osteoglossomorpha) from the continental early Cretaceous of southern Morocco. Am Mus Novit. 1999; 3260:1-12.

Taverne L, Nolf D, Folie A. On the presence of the osteoglossid fish genus Scleropages (Teleostei, Osteoglossiformes) in the continental Paleocene of Hainin (Mons Basin, Belgium). Belg J Zool. 2007; 137(1):89-97.

Torsvik TH, Amundsen H, Hartz EH, Corfu F, Kusznir N, Gaina C, Doubrovine PV, Steinberger B, Ashwal LD, Jamtveit B. A Precambrian microcontinent in the Indian Ocean. Nat Geosci [serial on the Internet]. 2013; 6:223-27. Available from: https:// doi.org/10.1038/NGEO1736

Tse TK, Pittman M, Chang M-M. A specimen of Paralycoptera Chang \& Chou 1977 (Teleostei: Osteoglossoidei) from Hong Kong (China) with a potential Late Jurassic age that extends the temporal and geographical range of the genus. PeerJ [serial on the Internet]. 2015; 3:e865. Available from: https://doi. org/10.7717/peerj. 865

Van der Bank FH, Kramer B. Phylogenetic relationships between eight African species of mormyriform fish (Teleostei, Osteichthyes): resolution of a cryptic species and reinstatement of Cyphomyrus Myers, 1960. Biochem Syst Ecol [serial on the Internet]. 1996; 24(4):275-90. Available from: https://doi. org/10.1016/0305-1978(96)00026-9

Van der Laan R, Eschmeyer WN, Fricke R. Family-group names of Recent fishes. Zootaxa [serial on the Internet]. 2014; 3882:1230. Available from: https://doi.org/10.11646/zootaxa.3882.1.1

Verba JT, Borges MLO, Silva MNF, Pinto LC, Neto JGR. Mice on menu: opportunistic feeding behavior of the Amazonian silver arowana Osteoglossum bicirrhosum. J Fish Biol. Forthcoming 2018.

Vérard C, Stampfli G, Borel G, Hochard C. The Indian promontory: A bridge between plate tectonics and life evolution models. Univers J Geoscie [serial on the Internet]. 2017; 5(2):25-32. Available from: https://doi.org/10.13189/ujg.2017.050202

Verma O, Khosla A, Goin FJ, Kaur J. Historical biogeography of the Late Cretaceous vertebrates of India: Comparison of geophysical and paleontological data. In: Khosla A, Lucas SG, editors. Cretaceous Period: biotic diversity and biogeography. Albuquerque: New Mexico Museum of Natural History and Science; 2016. p.317-330. (Bulletin, 71).

Vialle RA, Souza JES, Lopes KP, Teixeira DG, Sobrinho PAA, Ribeiro-dos-Santos AM, Furtado C, Sakamoto T, Silva FAO, Oliveira EHC, Hamoy IG, Assumpção PP, Ribeiro-dos-Santos A, Lima JPMS, Seuánez HN, de Souza SJ, Santos S. Whole genome sequencing of the Pirarucu (Arapaima gigas) supports 
independent emergence of major teleost clades. Genome Biol Evol [serial on the Internet]. 2018; evy130. Available from: https://doi.org/10.1093/gbe/evy130

Vitorino CA, Nogueira F, Souza IL, Araripe J, Venere PC. Low genetic diversity and structuring of the Arapaima (Osteoglossiformes, Arapaimidae) population of the AraguaiaTocantins Basin. Front Genet [serial on the Internet]. 2017; 8(159):1-10. Available from: https://doi.org/10.3389/ fgene.2017.00159

Wallus R. Larval development of Hiodon tergisus Lesueur with comparisons to Hiodon alosoides (Rafinesque). J Tenn Acad Sci. 1986; 61(3):77-80.

Watson LC, Stewart DJ, Kretzer AM. Genetic diversity and population structure of the threatened giant Arapaima in southwestern Guyana: implications for their conservation. Copeia. 2013; 104(4):864-72.

Wegener A. Die Entstehung der Kontinente und Ozeane. Braunschweig: F. Vieweg; 1915.

Wilson MVH, Murray AM. Osteoglossomorpha: phylogeny, biogeography, and fossil record and the significance of key African and Chinese fossil taxa. In: Cavin L, Longbottom A, Richter M, editors. Fishes and the Break-up of Pangea. London: Geological Society; 2008. p.185-219. (Special Publications; 295).

Xu GH, Chang MM. Redescription of Paralycoptera wui Chang \& Chou, 1977 (Teleostei: Osteoglossoidei) from the Early Cretaceous of eastern China. Zool J Linn Soc [serial on the Internet]. 2009; 157(1):83-106. Available from: https://doi. org/10.1111/j.1096-3642.2009.00532.x

Yabumoto Y. Kokuraichthys tokuriki n. gen. and sp., Early Cretaceous osteoglossomorph fish in Kyushu, Japan. Bull Kitakyushu Mus Nat Hist Human Hist. 2013; 11:67-72. (serie A).

Yue GH, Chen F, Orban L. Rapid isolation and characterization of microsatellites from the genome of Asian arowana (Scleropages formosus, Osteoglossidae, Pisces). Mol Ecol [serial on the Internet]. 2000; 9(7):1007-09. Available from: https://doi. org/10.1046/j.1365-294x.2000.00939-10.x

Yue GH, Ong D, Wong CC, Lim LC, Orban L. A strain-specific and a sex-associated STS marker for Asian arowana (Scleropages formosus, Osteoglossidae). Aquac Res [serial on the Internet]. 2003; 34(11):951-57. Available from: https://doi.org/10.1046/ j.1365-2109.2003.00949.x

Yue GH, Zhu ZY, Lin G, Lo LC, Feng F. Novel polymorphic microsatellites for studying genetic diversity of red Asian arowanas. Conserv Genet [serial on the Internet]. 2006; 7(4):627-29. Available from: https://doi.org/10.1007/s10592005-9061-1

Zhang J-Y. Morphology and phylogenetic relationships of Kuntulunia (Teleostei: Osteoglossomorpha). J Vertebr Paleontol [serial on the Internet]. 1998; 18(2):280-300. Available from: https://doi.org/10.1080/02724634.1998.10011057

Zhang J-Y. Phylogeny of Osteoglossomorpha. Vert PalAs. 2006; 44(1):43-59.

Zhang J-Y, Jin F. A revision of Tongxinichthys MA 1980 (Teleostei: Osteoglossomorpha) from the Lower Cretaceous of northern China. In: Arratia G, Schultze H-P, editors. Mesozoic fishes 2: systematics and fossil record. München: Verlag Dr. Friedrich Pfeil; 1999. p.385-396.

Zhang J-Y, Wilson MVH. First complete fossil Scleropages (Osteoglossomorpha). Vert PalAs. 2017; 55(1):1-23.

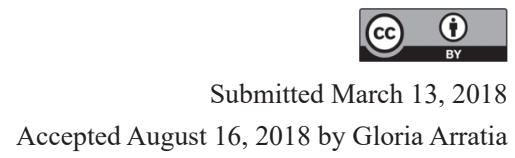

